\title{
GOVERNMENT TELEPHONES
}

THE EXPERIENCE OF $M A N I T O B A, C A N A D A$

BY

JAMES MAVOR, PH.D.

Professor of Political Economy in the University of Toronto: Author of "An Economic History of Russia," etc., etc.

TORONTO

THE MACLEAN PUBLISHING CO. 1917

NEW YORK

MOFFAT, YARD \& COMPANY I9I 6 


\title{
CONTENTS
}

\author{
INTRODUCTION . \\ - \\ Preface - • • • • • • • • • . $\mathrm{v}$ \\ CHAPTER \\ I The AcQuisition of the Bell System. . . I 3 \\ Early telephone development under private enter- \\ prise. Political agitation for public ownership of tele- \\ phones. Substantial reduction in telephone rates \\ promised under public ownership. Construction by the \\ Government of a competitive telephone system begun \\ in 1907. Government purchase of the extensive system \\ of the Bell Company, December 30, 1907. Promises \\ of the Government as to reduction of rates, commercial \\ management, and profitable operation.
}

COPYRIGHT, 1916. BY

MOFFAT, YARD AND COMPANY

NEW YORK

All rights reserved

II The Government System Under the First

Commission • $\cdot \cdot \cdot \cdot \cdot \cdot \cdot \cdot \cdot \cdot \cdot \cdot$ Telephone management vested in a Commission un-
er the control of the Government. Telephone policies der the control of the Government. Telephone policies
determined by political considerations; Governmental interference in the telephone management. A sectional increase in rates; telephone management dominated by political influence. Substantial profits from the first year's operations alleged by the Government. Real deficit in 1908 concealed by unsound accounting methods. A moderate rate reduction effected by the Government for political purposes. Labor difficulties. Deficit in 1909 concealed by the accounting methods prescribed by the Government. Construction policy of the Government ineconomical and marked by political abuses. Financial result in rgro again an apparent profit but a real loss. Fictitious profits disappear in IgII; an aggregate loss of over $\$ 300, \infty 00$. Government policies result in extravagance, inefíciency and 


\section{CONTENTS}

CHAPTER

discrimination in violation of promises. Long distance rates increased; proposal to revise exchange rates violently attacked by the public. Appointment of a Royal Commission, under the control of the Government, to investigate the Telephone Commission. Telephone mismanagement ascribed by the Royal Commission to the Telephone Commission instead of to the Government. Resignation of the Telephone Commission.

III The Government System Reorganised . . II5

Appointment of a single Telephone Commissioner followed by ostensible, but largely ineffectual, administrative reforms. Exchange rates increased; private telephone competition prevented. Telephone accounts still defective; a real loss of over $\$ 200,000$ in 1912. Inadequate provision against depreciation; real financial result in I9I3 again a deficit. Quality of service unsatisfactory. More administrative reforms, with extension of Government control; accounts show another deficit in r914 and improper use of telephone funds. The telephone management a campaign issue; extension of telephone service less than that in the United States; the passing of the Government. System used for political purposes by the new Government; an aggregate loss of $\$ 1,000,000$. Increasing deficits despite reports of profits; no prospect of relief from political abuses.

IV Conclustons . . . . . . . . . . 160

INDEX • • • • •

\section{PREFACE}

Although there are many difficulties inherent in Governmental management of industrial enterprises, and although in practically every country these difficulties have emerged in a more or less acute form, any new example of such management, especially one upon a considerable scale, is worthy of careful examination in order to determine to what degree, if at all, the inherent difficulties have been overcome either by the sagacity of the Government or by the coincidence of unusually favorable conditions. The test of practical experience is after all a good one; and the study of a living organism offers certain advantages over the study of an organism whose life history is closed. The disadvantage is that the living organism cannot without risk be cut open to see what is going on inside and that therefore the view of it must be an external one aided by diagnosis of its interior condition derived from the external appearances.

Under the influence of such reflections, during the summer of the memorable year 1914, I made an inquiry into the telephone system of Manitoba in order to ascertain the facts of the case. The Provin- 
cial Government had undertaken the ownership and operation of the telephones in the Province in 1908 ; the system was the largest under Government ownership in America; the Provincial Government had been by no means modest, either in promises or in announcements of performances; political capital had been raised upon the credit of the telephones by Cabinet Ministers and by candidates at elections; the alleged success of the enterprise had been widely advertised in the organs of the Government and in those of the advocates of "public ownership." On the other hand, politicians of the party opposed to the Government and the Opposition press, while in general approving of the policy of public ownership in the abstract, attacked the management of the Government, sometimes abusing the Government for extravagance and at other times for parsimony.

For the reason that a living organism was involved it was not easy to study the Government telephone system in Manitoba in actual operation. An exhaustive investigation into the contemporary technical and financial position of the system would necessarily have the character of a post-mortem. Such an investigation could moreover be competently conducted only by an impartial tribunal appointed by extra-Provincial authority and endowed with full powers to call for witnesses and documents, to take evidence upon oath, and to employ experts to examine the accounts and to appraise the plant.
My inquiry was necessarily of a much less formidable character. It was unavoidable to confine it almost altogether to the history of the system in so far as this history might be gathered from published documents, from contemporary newspapers, and from conversation with those who had had relations with the system or opportunities to know the course of events. The inquiry was greatly facilitated by the fact that a considerable mass of privately collected authoritative data relating to the subject fortunately came into my possession. The following pages are the result of a critical analysis of all the material at my disposal. Much of it was found to be inaccurate or biased and was therefore rejected. The narrative is scrupulously documented. It purports to set forth statements of fact readily susceptible of confirmation by any one who will take the trouble to consult the authorities which have been given. The conclusions which are drawn from the statements of fact seem to be irresistible, and they are stated with due reserve. The book must therefore be judged not as an attack upon the Manitoba Government nor upon its administration of the telephone system, but as a critical narrative of historical facts written from a point of view as impartial as possible.

It should be noticed that since my inquiry was concluded, the Government which was responsible for the purchase of the telephone system and for its ad- 
ministration during the first seven and a half years of Government ownership has ceased to exist. Some of its members were indicted for infringement of the criminal law; but the disagreement of the jury avoided a positive verdict. The present Government has been in existence only a short time; nevertheless, certain of its acts have been significant and ominous, and brief mention of these acts has been included in the narrative upon the basis of such printed authentic information as has recently come to my notice.

My inquiry included the telephone systems in the Provinces of Alberta and Saskatchewan where, as in Manitoba, Government ownership of telephones was adopted about a decade ago; but the systems in these Provinces are really too small to warrant extended consideration and I have taken no steps toward publishing my notes on them. However, it may be saici that, on the whole, the history - and results - of public ownership both in Alberta and in Saskatchewan have been analogous to those in Manitoba, although of course on a smaller scale.

JAMES MAvor.

Toronto, Ist September, I9I6.

\section{INTRODUCTION}

The invention of the telephone has probably produced more important social reactions than either the railways or the telegraph, although the telephone was introduced only forty years since, while the railway is nearly a century and the telegraph about three-quarters of a century old. The rapidity of the development of the telephone and the wide extension of its use have resulted from the application of the inventive genius of a large number of persons and from the encouragement of this genius by private enterprise, especially in America.

In Europe the telephones are now very generally owned by the Governments of the respective countries in correspondence with the view of the character and functions of the State which has developed in Central Europe during the past seventy-five years. This view involves the more or less complete subordination of the individual to the State and places enormous industrial and financial power in the hands of the governing groups. This power has been used to the full during recent years to establish and to continue the political pre-eminence of these governing groups. The interests of the public are lost sight of 
in the pursuit of the assumed interests of the State a body by no means identical with the mass of the public, but to be regarded rather as a body of persons whose interests are frequently opposed to those of the community of persons who constitute the nation.

There is no reason to believe that the policy which has been adopted by the Central European Empires and copied in a less extensive degree by the nations of western, southern and northern Europe, will be permanent. There have been many oscillations in historical times between what may be generally called medieval legislative and administrative restriction and modern freedom of the exercise of industrial functions. Whatever may be the tendency at a particular moment, there is no justification for nourishing illusions upon the alleged advantages of restriction over freedom, even although liberty has its drawbacks when pushed to the extreme of laisser faire.

The most obvious disadvantage of State collectivism is the degeneration of the administration into a bureaucracy of which red-tape becomes the symbol. Under the pressure of red-tape, invention is undoubtedly sterilized. As a matter of fact, the development of the telephone owes nothing to the State in any country. It has even been impeded by legislation and by the fear of the possibility of public confiscation. Under the technical conditions of tele- phony, it is probable that to no industry is State management less readily applicable than to the telephone industry. The intricacy of its technique and the highly fluid character of its methods mark it off decisively from certain industries whose technique has become settled and whose methods have come to be subject to routine. Whether or not industries of the latter character may be successfully administered by the State is open to discussion on general and on special grounds; but experience has shown that the methods of State administration are in general too cumbersome for their application to rapidly developing industries, with the doubtful exception of those which are of a definitely military or naval character. Even in the latter case experience has also shown the immense advantage of the distribution of technical skill in private establishments as a reserve which may in case of need be diverted to the service of the State. Where, from a mistaken view of the public interest, the State establishes a monopoly in its own favor, the inevitable result is the suppression of individual initiative and the absence of reserves of technical skill and efficient labor.

The argument which at the moment is frequently employed, that for military purposes in time of peace as well as in time of war it is important for the telephone to be in the hands of the Government, does not apply because if the telephone is in private hands the Government can in an emergency exercise the 
right of eminent domain and can commandeer the telephone service, even if it were not voluntarily placed at the disposition of the Government, although that would undoubtedly be done. Under private operation of telephones the Government has thus the advantage of having at its disposal a telephone system developed by private initiative without cost to itself and much more extensive than any which would have been at all likely to have been developed under Government auspices.

In democratic countries the people are in general severely censorious about Governmental actions and frequently even abusive of the executive Government; but an attitude of this kind is rarely of an intimate or effectively critical character, especially where the actions in question are connected with the operation of a complex industry. The minutix of such an industry are not understood by the public at large and if the State is the sole employer of the experts, the assistance of these experts is not generally available for an examination of the Governmental operations because they are professionally and economically at the mercy of the Government. Under the conditions of a competitive system where there is no Governmental or other monopoly, criticism may be continuous and effective. Under conditions of quasi-monopoly, the visitatorial power which is inherent in Governmental administration may properly be applied by Government inspectors and the public interest in the widest and deepest sense may be conserved by the Government, provided that the visitatorial power is exercised in an impartial manner. Where, however, the Government enters into direct competition with private enterprises, its visitatorial powers cannot be exercised disinterestedly and must therefore be ineffective; and where the Government exercises a legal monopoly, the visitatorial power disappears altogether and there is necessarily a tendency, not only towards administrative stagnation but also towards laxity, incompetence, and even fraudulent intromission with public funds. Thus a public service which is rendered by persons voluntarily cooperating as in a joint stock enterprise, when subjected to the possibility of Governmental inspection and criticism by Governmental agents having power to call for the production of all relevant data, is more likely to be conducted efficiently than a public service rendered directly by Governmental employees who are not exposed to effective criticism by any constituted body.

So also financial considerations are decisively against overloading Governmental agencies with pecuniary responsibilities. The investor in Government securities regards as the prime element in their saleability, not the alleged assets of the Government the value of which he is not competent to judge, nor the alleged earning power of any of the enterprises in which the Government may engage, for the eff- 
INTRODUCTION

ciency of the management of these enterprises is also beyond his knowledge; but the investor regards exclusively the taxing power of the Government and the apparent ability of the people to sustain the burden of the taxes which are likely to be placed upon them. In this estimate of the solvency of a community, the aggregate amount of the public debt, State and municipal, in relation to the numbers of the people is a prime factor. Increase in public indebtedness in excess of the increase of the numbers of the people means, therefore, an increase in the rate of interest because the security is proportionately diminished. In a country where the chief employment is agriculture, the principal security upon which debt is created is clearly land; and when the aggregate debt amounts to a high sum per acre of land in cultivation, it is time for the investor in public securities to consider the situation because the taxes being the first charge upon the land, the amount of these taxes determines all other credits, and defaults in tax payments involve flight. If the population deserts the land, all other forms of security in the country shrivel into no importance. The attitude of the investor is, therefore, perfectly sound.

The experience of every Government shows quite conclusively that Governmental management of enterprises of an industrial character is ineconomical. The ineconomical management of such enterprises arises from the following main causes:

\section{INTRODUCTION}

$I^{\circ}$ The absence of incentive to economical management; $2^{\circ}$ the employment of persons on political rather than on professional or technical grounds, and therefore the employment of a number of persons larger than is necessary; $3^{\circ}$ the reluctance with which the Government appoints persons of superior professional qualifications because of the relatively high salaries such employment involves, the employment of the cheap official being regarded as most easily defensible; $4^{\circ}$ the sale of the service, whatever it may be, at a price determined also rather on political than on technical grounds; and $5^{\circ}$ the restriction or the absence of competition.

The consequence of these conditions is that the cost to the nation of any service rendered by the Government is always greater than the cost of the same serv. ice rendered by competent persons other than those in the Government service. This consequence makes its appearance even although the functionaries of the Government practice the most scrupulous integrity. Where corruption enters, the consequences are sometimes even disastrous.

The demands of a growing population for the ex. tension of Governmental services of a strictly legiti. mate character are increasing so steadily that the taxbills as well as the debt of the modern State are sub. ject to constant expansion. If in addition to this legitimate increase in the amounts taken from the pockets of the people and placed at the disposal of 
the Government, the increase of taxes and of debt is amplified by Governmental adventures into ineconomically conducted industrial enterprises, the financial fabric of the nation becomes more and more seriously imperilled. The resources which should be available for the promotion of increased production are absorbed by the Government, a period of industrial stagnation supervenes, while individual enterprise and even individuality itself are checked. Under such conditions the more energetic of the population migrate to some other region where a smaller proportion of their earnings is absorbed by the Government and where they can enjoy a field for their powers less hampered by Governmental restrictions. This cycle of development has occurred in certain European countries, where the reactions of excess of Governmental control have worked themselves out. The continent of America has indeed been largely peopled by emigrants from Europe fleeing not from ancient feudal disabilities which have long ceased to have any tangible force, but from the modern feudalism which subordinates the individual to the assumed interests of the nation.

Even although a State enterprise were conducted profitably in a pecuniary sense, there would be a net public disadvantage unless the administration of it was such as to avoid the injurious effects not primarily of a pecuniary character. Too great stress is often laid upon the pecuniary factor alike by advocates and by opponents of public ownership. The public interest is affected not merely by balance sheets, but even more importantly by those influences not distinctly tangible but nevertheless real which contribute, along with the pecuniary factor, to determine the movements of population, the efficiency of industry, and the character of the people.

The Manitoba experience of Governmental management of the telephones is very instructive because it affords an illustration of the fatal weakness of political administration of industry. Although the scale upon which it has been attempted is small compared to the scale of a great country, it is nevertheless large in relation to the total activities of the Province. The purchase of the telephone system doubled the Provincial obligations and the expenditure on the telephones has formed a very material proportion of the total Provincial expenditure. Instead of proceeding cautiously and circumspectly in a new adventure as the Government might well have done, the Government plunged at once into a relatively vast extension of the telephone system without regard to the cost of it and considering only the temporary political advantage to the Government then in power. The public interest was wholly disregarded. The members of the Government who spoke most confidently about the telephone system knew, as they themselves admitted afterwards, nothing whatever about it. They promised things that 
in the nature of the case they could not possibly perform; for example, they promised to "cut the rates in two." They undertook to manage the telephone business without the assistance of superior technical advice and superintendence, while they hampered their own officers in the performance of their duty and handicapped the enterprise by saddling it with charges and overcharges of purely political origin. The accounts were presented in a manner of which no competent chartered accountant could approve and to which no such person could put his name without qualification. The Government pretended to entrust the telephone business to the Telephone Commission and yet from the beginning assiduously used the telephone business for political ends, reducing the rates without competent technical advice and forcing upon the Commission a series of financial arrangements of a highly questionable character.

The representations made by the Manitoba Government which acquired the system, and even those made by the present administration, as to accruing profits are absolutely without foundation. Until the Government writes off the amount which its own auditor regards as the excess value of the plant, as shown by the books, over the real construction cost of the plant, it is idle to talk of profits. Strictly speaking, the Manitoba Government Telephones have up till the present time involved the Province in a loss of upwards of a million dollars. This sum ought properly to be provided without delay "out of the general resources of the Province from taxation and placed in a fund in the hands of trustees independent of the Government for the security of the holders of the Telephone debentures and stock; otherwise these securities must in effect be depreciated by about ten per cent., taking into account the losses of the past alone and taking no account of the losses of the future. The politician accustomed to vague rhetorical generalities is used to denouncing all serious criticism; but the investor is not always easily deluded and one day the Province of Manitoba will find in a restricted money market and an abnormal rate of interest the consequences of the failure of its executive Government to transact its business in a businesslike way.

Among the financial reactions of the war must undoubtedly be the increase of the public debt of Europe, the great increase of the fund holding classes, and the urgent necessity for State economy. This economy can only be effected if the State relinquishes all but its necessary and obvious functions and refrains from increasing its total obligations. Only by such means can normal social conditions be re-established. Unless on the American continent a similar restrictive policy as regards State action be adopted, America will find itself burdened by overwhelming public obligations with all the social reactions to which these obligations give rise. 


\section{THE ACQUISITION OF THE BELL SYSTEM}

\section{EARLY TELEPHONE DEVELOPMENT UNDER PRIVATE ENTERPRISE}

Public telephone service in the Province of Manitoba was first given in 1880 by a private individual who opened a telephone exchange in Winnipeg and charged an annual flat rate of $\$ 60$ per instrument. In $188 \mathrm{I}$, however, this exchange was purchased by the Bell Telephone Company of Canada, which, in I 882, established exchanges in Brandon and Portage la Prairie. ${ }^{1}$ The Bell Telephone Company began its service at a time when there were only some 60,000 people in the entire Province, when the population of Winnipeg was only 8,000, and when Brandon and Portage la Prairie were only villages. ${ }^{2}$ As early as $r 884$, there were 340 subscribers in Winnipeg, ${ }^{3}$ a large number in proportion to the population at that time. Credit, therefore, is justly due the Bell Company for assuming the burdens and the risks of a pioneer, for anticipating the needs of the

1 The Winnipeg Telegram, January $16,1908$.

${ }^{2}$ Cf. Fifth Census of Canada, I9II, vol. i, pp. 522, 554-555.

3 The Winnipeg Telegram, January 16, 1908. 
public, and for developing a substantial business to serve the public.

Moreover, the successful development of the business was not a matter of smooth sailing; the economic seas in those days were extremely turbulent and often treacherous. Although a period of boom and prosperity accompanied the completion of the extension of the Canadian Pacific Railway to the Pacific Coast in I 886-87, yet the telephone industry at that time was too young to participate in the general expansion. Somewhat later, the growth of the business was retarded by the local depression which, beginning in I 888-89, continued for several years, - a depression which had as one of its causes a decrease in immigration. Furthermore, when a vig. orous immigration movement again set in - in I 895 - the nature of the immigration was such that little impetus was given to telephone development, for during the period I895-1900 the immigrants were predominantly of the peasant class with slender knowledge of the English language, self-contained habits, and small purchasing power. Thus it is obvious that up to I 900 the telephone business could not grow otherwise than slowly. Nevertheless, it is found that in 1900 the Bell Telephone Company served more subscribers, in proportion to population, in each of the towns of Winnipeg, Brandon and Portage la Prairie ${ }^{4}$ than are served to-day in the

${ }^{4}$ Cf. The Winnipeg Telegram, January 16, 1908.
Government-developed systems in Rome, Paris or Vienna. It was not until after 1900 that a rapid expansion of the service in Manitoba became possible. Between 1900 and I 908 the service did expand rapidly and the Bell Company anticipated and prepared for still further expansion. ${ }^{5}$

\section{POLITICAL AGITATION FOR PUBIIC OWNERSHIP \\ OF TELEPHONES}

In 1898 there arose, chiefly in the sparsely settled "rural municipalities," " a mild sentiment in favor of the installation and operation of telephone exchanges by municipal authorities. The first municipality to take up the matter actively was Neepawa, which had slightly more than 1,000 inhabitants. It was found, however, that the Municipal Act of the Province did not endow municipalities with power to establish commercial undertakings. Consequently, despite the fact that as a whole the municipalities were not anxious to embark in a venture involving the provision and risk of capital, to meet the individual case of Neepawa and to provide for a few similar cases, in 1899 the Provincial Legislature passed an Act permitting municipal ownership and operation of local exchanges. ${ }^{7}$

\footnotetext{
${ }^{5}$ Cf. pp. 26-28, infra.

"In Manitoba "rural municipalities" comprise rural territory exclusively. They are somewhat analogous to rural counties in Eastern Canada and in the United States.

${ }^{7}$ Statutes of Manitoba, 62-63 Vic., 1899 , cap. 25. Cf. also The Winnipeg Telegram, February 4 , 1908 .
} 
Since the municipal exchanges established under this Act were not entitled to connect with the long distance lines of the Bell Telephone Company, the Manitoba Government then began to consider, though in a rather vague and abstract manner, the expediency of constructing and operating long distance lines. No tangible action was taken until I905, when, on January 26th, the Select Standing Committee on Private Bills of the Provincial Legislature, in a report rejecting the application of two embryo telephone companies ${ }^{8}$ for charters of incorporation, recommended that during the legislative recess the Provincial Government should inquire into the whole subject of telephone service with a view to initiating public ownership and operation. ${ }^{9}$ The Government accepted the responsibility for this recommendation and promised a thorough investigation. ${ }^{10}$ To use the Premier's own word, this investigation took the form of a "quiet" inquiry on the part of himself and the Minister of Public Works. ${ }^{11}$ It is worthy of note, however, that the Government at about the same time requested the Dominion Government to amend the charter of the Bell Telephone Company so as to empower the

${ }^{8}$ The Independent Telephone Company of Canada and the Northwest Telephone Company.

9 Journals of the Legislative Assembly of Manitoba, Session I904-5, p. 73 .

${ }_{10}$ The Winnipeg Telegram, January 27, r905.

11 The Manitoba Free Press, Winnipeg, November 24, 1905.
Provincial Government to expropriate the Company's property in Manitoba. ${ }^{12}$ As the granting of any such request would obviously have seriously impaired the value of all charters whatsoever, the request was naturally refused. ${ }^{13}$

As a result of the "quiet" inquiry of the Premier and the Minister of Public Works, the Government resolved to commit itself to a specific policy of public ownership of telephones. The first definite announcement of this policy was made in a speech by the Premier on November 23, 1905. In this speech the Premier stated:

"The government is now prepared to recommend to the (Provincial) legislature the establishment of a telephone system in the province of Manitoba to be owned and controlled by the municipalities and the government jointly. ...

"We have reached this conclusion from the fact that the telephone is, and must be, necessarily one of the natural monopolies, and yet is one of the most desirable and necessary facilities for the despatch of business and for the convenience and pleasure of the people. Therefore, the price of telephones should be made so low that laboring men and artisans can have the convenience and advantage of the telephone, as well as the merchant, the professional man and

${ }^{12} \mathrm{Cf}$. Journals of the Legislative Assembly of Manitoba, Session I906, pp. 97-98.

${ }_{13}$ Cf. The Ottawa Free Press, April 26, rgo6; The Citizen, Ottawa, April 28, x906; The Herald, Montreal, September 15, 1906. 
the gentleman of wealth and leisure, and it is our intention to recommend to parliament (i. e., the Provincial Legislature) a proposition of this kind with a view of giving a telephone system to all classes at cost." 14

This announcement of the telephone policy adopted by the Government is highly significant in two respects. In the first place, the program contemplated by the Government provided that the local (exchange) service should be operated by the municipalities and that only the long distance lines should be controlled by the Provincial Government. Secondly, and more important still, is the fact that the only reason advanced for the adoption of the new policy was that rates could be considerably reduced under public ownership, since service would be given at cost. Absolutely no objection was taken to the character of the service furnished by the Bell Telephone Company. The public press, even while supporting the doctrine of public ownership, admitted that the Bell service was " efficient and satisfactory." 15 Throughout the politically-conducted agitation for public ownership of telephones, the discussion centered around the question of rates; all later references by the politicians to the quality of the service were purely incidental and secondary.

Although the Government had thus already com-

14 The Manitoba Free Press, Winnipeg, November 24, 1905.

15 The Manitoba Free Press, Winnipeg, November 25, 1905. mitted itself to a policy of public ownership, nevertheless in its session of 1906 (January 29, 1906) the Provincial Legislature, on the motion of the Government, appointed a committee to inquire into the telephone question. ${ }^{16}$ The chairman of this committee was the Attorney-General of the Province. The committee took evidence in Manitoba and inspected the independent telephone systems in several United States cities and, on February 27, 1906, made its report, which consisted of a series of resolutions to the effect that

(a) The telephone should be owned and operated as a Government and municipal undertaking;

(b) The existing rates in Manitoba were exorbitant and could be considerably reduced;

(c) The Government should build the long distance lines and the municipalities should supply the local systems. ${ }^{17}$

On February 28, 1906, the Government brought before the Legislature a Bill based on these resolutions. $^{18}$.In a lengthy speech introducing the Bill, the Attorney-General contended that the Bell Company's "theory" that unit costs increased with the number of telephones in use, was "fallacious," and declared: "I am satisfied that the present rates in Canada could be cut in two and still leave a very satisfactory

\footnotetext{
${ }^{10}$ Journals of the Legislative Assembly of Manitoba, Session 19o6, p. 35 .

17 Ibid., pp. 88-90.

${ }^{18}$ Ibid., p. 94.
} 
profit." 19 The Bill passed the Legislature, and became law on March $16 ;{ }^{20}$ but the Government were content with having secured what they regarded as statutory sanction for whatever course they might eventually decide to pursue, and they took no immediate action toward carrying out their policy.

The political situation in Manitoba in 1906 was such that, in view of the approaching elections, both the party in power and the Opposition were desirous of bringing forward some project which might be popular without being politically dangerous. Such questions as the question of compulsory education were considered too complicated and too thorny to be injected into the political arena. The question of public ownership of telephones, on the other hand, was assumed to be both a simple one and one which would be immediately popular, as telephone service could readily be offered to everybody at cost. Both parties, therefore, sought to advance their political fortunes by advocating public ownership: the proposition of the party in power was the combined Government and municipal system already described, whereas the Opposition - as a plank in its political platform - urged that both local and long distance service be operated by the Government. ${ }^{21}$

${ }^{19}$ Resolutions and Memorials of the Legislative Assembly of Manitoba respecting Public Telephones. Winnipeg, 1906.

${ }^{20}$ Statutes of Manitoba, 5-6 Edw. VII, r906, cap. 89.

21 Cf. the Manitoba Free Press, Winnipeg, February 2n, rgo7.

\section{SUBSTANTIAL REDUCTION IN TELEPHONE RATES} PROMISED UNDER PUBLIC OWNERSHIP

Although the members of the Government knew nothing about the telephone business (a fact which they admitted afterwards ${ }^{22}$ ), nevertheless throughout the campaigns which preceded the municipal election of December, 1906, and the general election of 1907 they continued to make high-sounding and reckless promises regarding the rate reductions which could be effected under their proposed policy. The chief spokesmen of the Government were the Premier and the Attorney-General. On September 5, 1906, the latter publicly declared that "the Government will be able to accomplish a result that will cut the cost of the telephone in two." ${ }^{23}$ In an interview published on December ro, the same official said: "In the country the reduction will be one-half the existing rates." 24 On the same day the Premier said: "It is simply a matter of those who use telephones paying for them, and also, only to pay half what the Bell people now charge." 25 Three or four days later the Premier said: "We will more than cut the Bell figure in two "; ${ }^{2 \theta}$ and, speaking in Neepawa on December 2oth, he said that by one

\footnotetext{
22 Cf. p. 96, infra. tion, September $5,1906$.

${ }^{25}$ The Winnipeg Telegram, December 10, 1906.

${ }^{25}$ The Winnipeg Telegram, December 11, 1906.

${ }^{28}$ The Winnipeg Telegram, December 15, 1906.
}

${ }^{23}$ Speech before the Canadian Independent Telephone Associa- 
year from that time "they would be able to speak over a Government-owned long distance line from Neepawa to Winnipeg at less than half what is charged by the Bell Telephone Company at the present time." ${ }_{27}$ These glib promises are typical of many others which the Government asked the voters of the Province to believe.

Some months after the Government had openly committed itself to a policy of public ownership and after promises to cut the Bell rates in two had already been made, the Government perceived that it would be advisable to give the case the appearance of being founded on a substantial and scientific basis. Consequently, on August 2 I, 1906, it called to its aid a telephone expert who was known to agree with the Government's contention that rates could be greatly reduced. As a matter of fact, however, this expert was secured primarily to direct "a campaign of education along telephone lines," ${ }^{28}$ that is, he was to be the publicity manager for the Government's proposal. In that capacity the expert immediately plunged into the thick of the political campaign, making speeches throughout the Province in which he addressed himself especially to the farmer. For example, at Brandon, on October 29, 1906, he said: "In regard to the price at which a telephone

27 The Winnipeg Telegram, December 21, 1906.

28 Letter of Attorney-General requesting the services of the expert; quoted by the expert in a speech at Brandon, Oct. 29, 1906, reported in the Manitoba Free Press, Winnipeg, Oct. 30, 1906. service can be provided by the Government, I might say that it is absolutely certain that the majority of your farmers can obtain rural service at $\$ \mathrm{I} 2$ a year, and that the residents of every municipality can obtain a telephone at the same rate." ${ }_{29}$ Again, at Birtle, on October 3 Ist, he said: "We are absolutely satisfied that with few exceptions every farmer in this Province can be supplied with telephone service at the rate of $\$ 1.00$ per month. I know the Bell Telephone Company will take exception to that." 30 As a climax to the campaign preceding the municipal elections the Government issued and widely circulated a pamphlet by this expert. ${ }^{31}$ This pamphlet was primarily designed to influence the voters in the rural districts and in it were reiterated the statements that a rural telephone service could be furnished for $\$ 1.00$ a month. ${ }^{32}$

CONSTRUCTION BY THE GOVERNMENT OF A COMPETITIVE TELEPHONE SYSTEM BEGUN IN 1907

In order to ascertain the measure of popular support which would be accorded an immediate execu-

29 The Manitoba Free Press, Winnipeg, October 30, 1906.

30 The Manitoba Free Press, Winnipeg, November 3, 1906.

${ }^{31}$ The Manitoba Government and Public Ownership of Telephones, Winnipeg, I 906.

32 Although the Government later endeavored to throw upon their expert the responsibility for their failure to fulfill their promises, it should be observed that the Government had entered upon their career of extravagant promise long before the advent of the expert, whose views, also, were known to the Government before his services were engaged. 
tion of their scheme of joint Government and municipal ownership, the Government had arranged that the following question should be submitted to the voters in each municipality at the municipal elections in December, 1906: Shall this municipality own and operate its own telephones? The vote purported to be a test vote pure and simple: an answer in the negative would mean that the municipality would refuse to construct a local system in cooperation with the Government; an answer in the affirmative would signify merely that the Municipal Council, at its own discretion, could take steps to install a local system in pursuance of the Government's general scheme. ${ }^{33}$ In spite of the fact that the promises of the Government on the eve of the election were unusually reckless, and although the aggregate popular vote favored the affirmative, a majority of the municipalities of the Province declined to cooperate with the Government. ${ }^{34}$ The Government, however, obstinately refused to accept the result of the vote as a rejection of its policy; on the contrary, it was actually interpreted not only as an endorsement of the plan, but even as a direct mandate from the people to carry out the program of joint Government and municipal ownership. The Government therefore began to urge the installation of exchanges

${ }^{33}$ Statutes of Manitoba, 5-6 Edw. VII, 1906, cap. 99. Cf. the Manitoba Free Press, Winnipeg, September 29, 1906.

34 The Manitoba Free Press, February 12, 1907. by municipal authorities, and it prepared to begin the construction of some long distance lines, relying upon the power conferred by the Act of March I6, I 906.

The general elections were held in 1907 and the Government was returned to office. Thereupon the Government immediately announced that its proposed telephone policy was vindicated and that it was supported by public opinion..$^{35}$ At the same time it found itself in a position to take effective action, for the financial position of the Province had been considerably improved between 1900 and $1907 .{ }^{36}$ It was soon learned, however, that the vote of the municipal elections was not meaningless and that the municipalities would not install local exchanges as they were expected to do. Even the municipality of Winnipeg, where for several years there had been an intermittent agitation for a local municipal system, refused to submit to the Government's proposition. ${ }^{37}$ The Government, therefore, was confronted by a dilemma : either to abandon the proposed scheme altogether or to embark upon a Government-owned system of local exchanges as well as of long distance lines, which was exactly the policy

${ }^{35}$ Cf. Letter of the Premier to the President of the Bell Telephone Company, dated Winnipeg, March 11, 1907. Sessional Papers. Legislative Assembly of Manitoba. Session 19o8, p. 356.

${ }^{36}$ Cf. Public Accounts of the Province of Manitoba for the respective years. These Accounts are printed as Sessional Paper No. $I$ in the Sessional Papers of each year.

37 The Manitoba Free Press, Winnipeg, April 4, 1907. 
advocated by the Opposition. The Government chose the latter course as the lesser of the two evils and inaugurated the new program by issuing Provincial bonds to the amount of one million dollars, with the proceeds of which the construction was begun in September, 1907, of a telephone exchange in Winnipeg in opposition to the local system of the Bell Company. ${ }^{38}$

GOVERNMENT PURCHASE OF THE EXTENSIVE SYSTEM OF THE BELL COMPANY, DECEMBER 30, I9O7

It is necessary to pause an instant at this point to direct attention again to the important fact that during 1906 and 1907 the Bell Telephone Company vastly improved and increased its plant and extended its service. As the Opposition seems to have overlooked this significant fact in their later criticisms, the following statement has been taken from the columns of the leading Opposition newspaper of the Province:

"On February 21, I906, Lewis B. McFarlane, general manager of the Bell Telephone Company of Canada, ... stated that the capital investment of the company in Manitoba (on December 31, 1905) was $\$ 1,360,787 \ldots$

"In the year I 906 the Bell spent approximately

${ }^{88}$ The Manitoba Free Press, Winnipeg, September 6, 1907.
$\$ \mathrm{I}, 000,000$ in Manitoba in various works, putting in new switchboards, new conduit work and long distance wiring. During the last year a new exchange building has been erected in Fort Rouge at a cost of $\$ 40,000$, and a great deal of the underground and cable work has been done preparatory to opening this exchange. Then there has been a large addition to the Winnipeg switchboard. A modern central energy, multiple switchboard has been installed in Brandon, and the whole work in the city has been reconstructed. . . .

"In 1905 there were 6,224 subscribers and 892 miles of long distance and rural lines. To-day there are more than 14,000 subscribers in the province and more than 2,500 miles of pole lines." 39

In other words, this Opposition statement shows that during one year ( 1906) the plant investment of the Bell Company had almost been doubled, while the number of subscribers was more than doubled during the two years 1906 and 1907 . Moreover, in a speech before the Legislature on February I3, $1908,{ }^{40}$ the Premier stated that in 1907 over $\$ 700$,ooo was expended on the Bell system, an amount which, although less than the expenditure in 1906, was still over one-half as great as the entire investment up till December 3I, I905. In view of this re-

39 The Manitoba Free Press, Winnipeg, January r, 1908.

${ }^{10}$ The Winnipeg Telegram, February 14, 1908. 
markable growth, the Bell Telephone Company certainly seems adequately to have met the real demands of a period of prosperity and expansion.

The Government realized that to compete with the Bell would be an extremely hazardous venture; and it considered that it would be much more economical and advantageous to buy a ready-made system than to go through the slow and laborious process of building up a business of its own. The effort to obtain authorization to expropriate the property of the Bell Company having proved futile, ${ }^{41}$ on December I 2, 1907, the Government asked Mr. Sise, President of the Bell Company, to come to Winnipeg in order to discuss the project of a purchase of the Bell system in Manitoba. Mr. Sise responded, but set a price of $\$ 4,000,000$ on the Bell property, stating that he did not anticipate that the Bell would suffer by the introduction of the Government-owned system and that he did not want to sell. After negotiations an agreement was, however, effected, and on December 30 , 1907, the Bell property and business in Manitoba was purchased by the Government for $\$ 3,300$,ooo-since there were 14,042 Bell telephones at the date of transfer, a price equivalent to $\$ 235$ per telephone - a further sum of $\$ 100,000$ being paid for supplies. The Government was to assume charge of the plant on January I 5, I908. To meet

${ }^{41}$ Cf. pp. 16-17, supra. the purchase price the Government issued $\$ 3,500$,ooo of $4 \%$ Provincial bonds, $\$ 100,000$ of these bonds being held in reserve by the Treasury Department. Although the bonds could not have sold at that time for more than 92 or 93 , the Bell Telephone Company accepted them in payment at par value. ${ }^{42}$

The Opposition complained that the purchase was rushed through within two days before the opening of the legislative session; but the Government cited the Act of March 16, 1906, as sufficient authority for their action and they never submitted the specific transaction to the representatives of the people for ratification. The Opposition also contended that the Bell plant was out-of-date and criticized the price paid by the Government as excessive. The main points of the Government's answer to these criticisms were as follows. The Government pointed out:

(a) That the Chief Engineer of the Provincial Department of Railways, Telephones and Telegraphs had reported ( $\mathrm{I}$ ) that the construction of the Bell plant " has been well done, and is up to modern practice generally"; and (2) that "the physical

42 Letter of the Premier to the President of the Bell Telephone Company, dated Winnipeg, Dec. 30, 1907. Sessional Papers. Legislative Assembly of Manitoba. Session 1908, p. 359. Cf. the Manitoba Free Press, Winnipeg, January 1, 1908. The original documents prove that the overtures in the transaction were made by the Government as early as March, 1907. Cf. correspondence between the Premier and the President of the Bell Company. Sessional Papers. Legislative Assembly of Manitoba. Session roo8, p. 356 et seq. 
plant is in a good state of repair, and is being kept so "; ${ }^{43}$

(b) That at the time of purchase between 30 and 40 per cent. of the Bell plant represented advance construction for future needs; ${ }^{44}$

(c) That the depreciated value of the Bell plant had been placed at $\$ 3,210,098$ by the Chief Engineer of the Provincial Department of Railways, Telephones and Telegraphs; ${ }^{45}$

(d) That the criticisms were largely based on the state of the company's plant in 1905, whereas the plant had been much more than doubled in 1906 and $1907 ;{ }^{46}$

(e) That competition with the Bell Company would have been costly, while the number of Bell telephones was so great that there was no room for a dual system; ${ }^{47}$

(f) That an allowance of Io per cent. should be added to the plant value on account of forced sale, franchise, and good will; ${ }^{48}$

(g) That the discount on the bonds given in payment was at least $71 / 2$ per cent. ; ${ }^{49}$

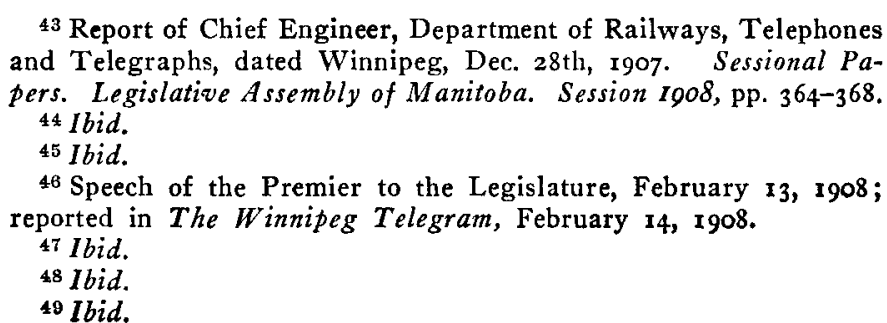

(h) That the purchase of a going concern eliminated the necessity for the payment of interest on the large amount of capital invested in non-revenueproducing plant during the period of construction. ${ }^{50}$

Although the answer of the Government has never had any appreciable effect on its critics, the impartial observer cannot fail to be impressed with the strength of the Government's case. In view of the numerous intangibles which the Government pointed out were legitimately involved in the purchase, the fairness of the price cannot be determined from any mere valuation of the plant. At the time the purchase was effected the Opposition press admitted that " at the present market price of provincial bonds the price paid for the system at the present time is, in round figures, about $\$ 3,000,000 . "{ }^{51}$ If similar allowances be made for the other factors besides bond discount, there is no escape from the conclusion that the price paid for the plant and its inseparable intangibles was not unreasonable.

The result of the transaction was that the debt of the Province was doubled at a stroke, while the Province, without fully realizing it, had committed itself to still larger expenditures for future telephone purposes. Moreover, it should have been realized, though it was not, that these expenditures would inevitably prevent expenditures in public works which

50 Speech of the Premier to the Legislature, February 13, 1908.

51 The Manitoba Free Press, Winnipeg, January 1, 1908. 
might be undertaken as belonging to unquestionably Governmental functions. Thus, when at a later date the development of the extensive water powers of the Province was proposed, ${ }^{52}$ the Province was unable to undertake this important public work because its credit was so deeply involved in the telephone enterprise that the necessary funds could not be procured.

PROMISES OF THE GOVERNMENT AS TO REDUCTION

OF RATES, COMMERCIAL MANAGEMENT, AND PROFITABLE OPERATION

Immediately upon the announcement of the acquisition of the Bell system, the Government renewed its pre-election pledges as to reduction of rates $^{53}$ and as to profitable operation. The Minister of Railways, Telephones and Telegraphs ${ }^{54}$ even went so far as to estimate the expected amount of profit and announced that, after the deduction of all interest and sinking fund charges, there would be

$52 \mathrm{Cf}$. the report on the Projected Hydro-Electric System for the Province of Manitoba, by H. A. Robson, K. C., formerly Public Utilities Commissioner.

53 It should be noted that the promises as to rates which were made before the purchase of the Bell system was contemplated, were by no means prejudicially affected by the eventual purchase; indeed, the sole effect of the purchase would be to facilitate the fulfillment of these promises, inasmuch as the purchase was consummated by the Government as being, in the end, more economical and advantageous than the construction of a public-owned system.

${ }^{54}$ A Department of Railways, Telephones and Telegraphs, with a small technical staff, had been created as early as March, r907. Cf. the Manitoba Free Press, Winnipeg, March 16, r907. an annual surplus of over $\$ 30,000$, and that this amount would be increased to over $\$ 100,000$ by the elimination of head office expenses, which were declared to be unnecessary. ${ }^{55}$ The Government also undertook another public pledge and declared its intention of managing the telephone system as a commercial undertaking, i. e., on a strictly business basis, without political partisanship or influence. On the very day of the purchase, the Premier stated: "We shall operate the system by a commission, which will be free from all partyism." 56 In speaking of the contemplated Commission before the Legislature on January 7, 1908, the Premier said: "We have reached the conclusion that it is in the public interest that that commission . . . shall be free, as far as it is possible to make it, from party or political influence. . . . We have reached this conclusion for the reason that it is a commercial business; that it enters into the life and business of every home and office that uses a telephone; that the service to be efficient and satisfactory must be of the very best type or kind; and to secure that we must have men in charge who have no interests to serve - who are subject to no influence other than such as is of a telephone kind or character. ... And as the credit of the province has been used to purchase this service, it is the bounden duty of the government ... to place the

55 The Manitoba Free Press, Winnipeg, February 4, 1908. ${ }^{56}$ The Manitoba Free Press, Winnipeg, January 1, 1908. 
service in the hands of men whose life business is to give a telephone-user the best service possible, and have him realize that anything that is done is with a view of bettering the service, and is not done from a political or a party motive or influence." ${ }_{57}$ Speaking before the Legislature on February I3, I908, the Premier said: "It is the settled policy of the government and those who support it, that there shall be no influence exercised or used upon that commission in any way, in so far as it affects the management and operation of that system. We want the system to be an ideal one, one that will enjoy the confidence of my honorable friends opposite" - i. e. the Opposition - " to as great an extent as it enjoys the confidence of the gentlemen on this side" - i. e. the Government party. "We feel that it must be kept clean and clear of all party politics or influence." 58

To recapitulate, in order to make political capital, both political parties in Manitoba diligently promoted a belief that the people of the Province were paying tribute, in the form of exorbitant charges, to the limitless greed of a conscienceless octopus. In those days little effort was required to arouse a popular sentiment against any relatively large vested interest. It was but natural, then, that within a comparatively short time the shrewd politicians were safely able to force the telephone question to the

57 The Manitoba Free Press, Winnipeg, January 8, 1908.

${ }_{58}$ The Winnipeg Telegram, February $14,1908$. front. These politicians, too, did not fail to grasp the usefulness of a promised rate reduction as a vote-catching device. Government ownership of telephones was adopted in Manitoba, not because of dissatisfaction with the quality and efficiency of the service furnished by the Bell Telephone Company and not because of any administrative abuses on the part of that company, but primarily as a means of reducing rates to the end that political advantage might be secured by the Government.

For the purpose of securing popular support, the Government made a number of definite promises both before and after the acquisition of a publicowned telephone system. Among these promises were three cardinal pledges, explicitly and unequivocally undertaken:

I. That the Bell rates would be greatly reduced, "cut in two" being the term generally employed;

2. That the entire cost of operating the service would be borne by the telephone users, i. e., that the system would be self-supporting;

3. That the management of the system would be on a strictly commercial basis, absolutely free from political considerations or influence.

In considering the history of the Government telephone enterprise, these pledges must constantly be borne in mind. 
II

\section{THE GOVERNMENT SYSTEM UNDER THE FIRST COMMISSION}

\section{TELEPHONE MANAGEMENT VESTED IN A COMMIS- SION UNDER THE CONTROL OF THE GOVERNMENT}

THE management of the Government's newlyacquired system was committed to a Telephone Commission of three members, this Commission being nominally independent but actually subordinated to a Department of Telephones and Telegraphs, presided over by a Cabinet Minister. The Commissioners appointed by the Government were men of many years' telephone experience in the service of the Bell Telephone Company in the Northwest and were unquestionably well qualified for the task of managing a telephone system under normal conditions. ${ }^{1}$ Moreover, all three were recognized not only by the Company and by the Government, but also by the public, as men of high personal character and as entirely detached from any political affiliation. These Commissioners were Mr. F. C. Pater-

1 Cf. The Gazette, Montreal, January 4, 1908. son, who was appointed Chairman, Mr. W. H. Hayes, the Commissioner Engineer, and Mr. H. J. Horan, the Commissioner Auditor. The salary of the Chairman was fixed at $\$ 5,000$ per annum; the salaries of the two other members were set at $\$ 3,000$ each. ${ }^{2}$ It is inconceivable that men of such proved ability should suddenly become incompetent; if inefficiency and extravagance appear, they must be charged to causes beyond the control of the Commission.

The Commissioners were officially appointed on January I 5 , 1908, and took up their duties on that day. The functions of the Commission, as originally fixed, gave it the power to operate the system, to appoint and discharge employees, to fix rates, and to connect subscribers to the system, provided that if the cost of such connection exceeded $\$ 500$, the approval of the Minister of Telephones and Telegraphs must first be obtained. ${ }^{3}$ The Commission was not empowered to purchase supplies, but was required to send requisitions for all supplies to the Minister at least three months before the supplies were needed; and the Minister retained an engineering staff of his own in control of construction. ${ }^{4}$ At

${ }^{2}$ Order-in-Council No. 12545. Sessional Paper No. 14. Sessional Papers. Legislative Assembly of Manitoba. Session 1908, pp. $574-5$.

3 Ibid.

"Order-in-Council No. 12545. Cf. Statutes of Manitoba, 7-8 Edw. VII, r go8, cap. 63 . 
this point it should be observed that, whereas in the Bell Company's organization the local administrative officers were subject to the supervision of, and received assistance from, the staff of experts at headquarters (Montreal), when the Commissioners entered the service of the Manitoba Government they found themselves suddenly deprived of the assistance which they had received from the Montreal staff of the Bell Company, all supervision and control being vested in the Minister, or, in reality, in a group of politicians who had no knowledge whatever of the telephone business.

TELEPHONE POLICIES DETERMINED BY POLITICAL CONSIDERATIONS; GOVERNMENTAL INTERFERENCE IN THE TELEPHONE MANAGEMENT

In spite of the Government's explicit pledge that political considerations would be eliminated from the telephone management, such considerations appeared at the very outset and, as a matter of fact, dominated the Telephone Commission throughout its existence. The first effect of political control was, perhaps, in the matter of construction. The votes of the farming population being essential to the political welfare of the Government, the Government, once in control of the system, made haste to curry favor with the farmer by forcing the Commission to adopt a policy of rapid extension of rural lines without regard to the legitimate demand for this exten- sion of the service. There can be no doubt that the Commissioners pointed out the detrimental effects such an unscientific and unnecessary policy would have both upon expenses and upon organization; ${ }^{5}$ but remonstrance on the part of the Commissioners was futile, since they were dealing with, and were under the control of, astute politicians whose sole object was the retention of political power. ${ }^{6}$ Moreover, the policy of rapid construction included the provision of a considerable amount of free service and other discriminations in the rural districts, which were also in violation of the promise of non-partisan commercial management. ${ }^{7}$

Nor were these the only immediate effects of the political influence which surrounded the administration of the system. Even in matters of detail the Commission was subjected to pressure by members of the Provincial Cabinet. For example, after the Government's acquisition of the telephone system, one of the members of the Government exerted an irresistible influence upon the Commission to requisition an excessive number of poles, since the

\footnotetext{
${ }^{5}$ Cf. Stenographic Report of Evidence before the Royal Commission of Inquiry 1912 (typewritten), vol. i, p. 35 et seq. This Report is mentioned on p. 97 infra and is hereafter cited as Stenographic Report.

${ }^{6}$ The members of the Government who really determined telephone policies conveyed their instructions to the Commission orally, carefully refraining from committing themselves to documentary evidence which might be brought against them.

T Stenographic Report, vol. i, pp. roo-ror.
} 
contract for these poles could be placed with certain clients of his who were then involved in financial difficulties and the payment for the poles would relieve the pressure upon them. ${ }^{8}$ "Recommendations" even as to the employment of individuals were made by Cabinet Ministers; and although the Commission was under no statutory obligation to act upon these " recommendations," nevertheless it was well understood that the smooth working of the Commissioners' relations with the Government depended upon the adoption of the "recommendations," which were always orally communicated. Moreover, it will be recalled that the prescribed functions of the Commission did not include the purchasing of supplies, the control over such purchases being specifically reserved to the Government; that is, while the Commission prepared requisitions, the Government decided to whom contracts should be given. These contracts were awarded for political effect and were made instruments by means of which the party political organization was strengthened and party funds were collected from the contractors. This system, of course, is one which is practised by both political parties, though party interest prevents its sordid de-

${ }^{8}$ Cf. p. ro3, infra. An advertisement calling for tenders for 25,000 poles appeared in the newspapers of November 5,1908 . On the excessive number of poles purchased by the Commission in consequence of political pressure, see e: g. Stenographic Report, vol. iii, p. 143 et seq. tails from coming to the knowledge of the public except in rare and flagrant cases.

In the realm of finance, too, the Government failed to keep its promises of commercial management. From the beginning of the Government telephone service, the Commission was required to pay all its " receipts from earnings" into the Provincial Treasury and to draw upon the Treasury for the funds to meet all expenses; ${ }^{9}$ and thus there was neither created nor maintained any reserve against depreciation or, in fact, any reserve of any kind whatever. ${ }^{10}$ The natural result of such political accounting methods was that in each of the first three years of Government operation the books of the system showed an "excess of revenue over expenditure" wnich was erroneously described as a "surplus" ; while political credit was taken for these fictitious profits and the success of Government operation of telephones in Manitoba was widely trumpeted. Furthermore, it must again be noted that the Government continued such unsound methods of accounting in direct opposition to the advice of the Telephone Commission. The Commission pointed out that an annual depreciation charge of at least 6 per cent. upon plant cost ought to be made, but still the Commission was not permitted by the Government

9 Order-in-Council No. 12545.

10 Stenographic Report, vol. i, pp. 28-29. 
to set aside any reserve, even to meet reconstruction expenses. ${ }^{11}$

A SECTIONAL INCREASE IN RATES; TElEPHONE MANAGEMENT DOMINATED BY POLITICAL INFLUENCE

In spite of the Government's glib promises to the effect that the Bell rates were to be "cut in two," instead of a reduction in rates, the immediate result of Government ownership was a substantial, though sectional, increase. Under the Bell Company, the telephones of physicians, dentists and nurses had been granted a reduced rate; on February 20, I908, the Commission issued a circular announcing that thereafter such telephones would be charged for at the regular rate for business service, representing an increase of 25 per cent. ${ }^{12}$ Although this increase cannot, in itself, be especially condemned, nevertheless the Commission's action caused much controversy because it was such a flagrant violation of the Government's promises in regard to rates. Almost from the beginning the Telephone Commission found itself the target of hostile criticism, for although it had not been in the least responsible for the promises made by the Government, yet it was in the position of having to bear the responsibility for any failure to fulfill these promises.

11 Stenographic Report, vol. i, p. $3 \mathbf{I}$ et seq. Cf. also p. 55, note 42, infra.

$12 \mathrm{~A}$ copy of this circular letter is given in the Winnipeg newspapers of February 22, I908.
The immediate action of the Government in relation to their pledges having thus been briefly indicated, with these pledges in mind we are now prepared to follow the history of the enterprise. So far as practicable, this history will be given chronologically.

In the first place, notwithstanding the activity of the Government in construction work, they did not move fast enough to suit the Opposition. For instance, about three months after the purchase, the Opposition paper in Winnipeg denounced the Government for failing to provide at least $\mathrm{I}, 000$ miles of additional long distance lines. ${ }^{13}$ The political effect of such attacks was not lost upon the Government, who saw themselves forced to adopt a policy of the most feverish energy in construction, - an il. lustration of the fact that, after all, both political parties have been implicated in the mismanagement of the system. As has already been indicated, the speed at which construction was forced in the years I908 to I9I I was very costly; but the Commission was told to go on, that the Province could sustain the financial burdens involved. The Commission was obliged to erect unprofitable and unnecessary rural lines, to convert toll offices into exchanges before the amount of business warranted the change, to give night service in small exchanges where day service would have sufficed and to give free service

\footnotetext{
13 The Manitoba Free Press, Winnipeg, April II, 1908.
} 
between certain exchanges, ${ }^{14}$ - all of which was done at the instance of the Government in order to placate political opponents or to gratify supporters, and also in order to increase the patronage of the Government and to promote the illusion that the system was prospering. Moreover, attention should again be called to the fact that it was impossible to expand the internal organization to keep pace with the expansion in plant. Also, the scarcity of labor compelled the Commission to keep an excessive number of men on the permanent pay-rolls, while, as a matter of actual practice, the Commission was unable to select its employees. ${ }^{15}$ Men were forced upon foremen by members of the Provincial Legislature; Cabinet Ministers made "recommendations" over the telephone, while at the same time solemnly assuring the public that the Commission was not being interfered with and that the business was being conducted on a commercial footing. Indeed, hangers-on of both parties were always on the look-out for political crumbs; in the words of one of the Commissioners it is found that "the whole running of the system has been permeated with politics." ${ }^{16}$ Finally, while the Government was playing fast and loose with the real interests of the Province, the people were

\footnotetext{
14 Memorandum by the Commissioner Auditor (typewritten) prepared early in 1912.

15 Ibid.

10 Ibid.
}

scarcely less culpable. They appeared to be demoralized by the fact that the telephone was a Government undertaking and exploited the telephone administration in every way. ${ }^{17}$

After the Minister of Telephones and Telegraphs (i. e., the Government) had awarded most of the contracts for the first season of construction, ${ }^{18} \mathrm{a}$ change in the form of administration took place. The existence of a Ministerial Department of Telephones and Telegraphs in addition to the Telephone Commission had led to division of control and responsibility as well as to duplication of labor. Six months after the transfer of the Bell system to the Government, this dual control became not only obviously absurd but also positively embarrassing to the Government, for both the telephone users and the general public regarded the Telephone Department, and not the Telephone Commission, as the real authority and therefore complaints and demands

17 A side-issue of the Government's construction policy should be mentioned here. Even after the Bell system in Manitoba had been acquired, the Government did not entirely abandon its cherished attitude toward municipal ownership of local exchanges, but continued to encourage municipalities to install local systems by offering to provide plans, to superintend construction, to supply the necessary materials at cost, and to guarantee the debentures issued by the municipalities to secure the funds necessary for the establishment of such systems. This policy was so far from being successful, however, that not only were few new municipal telephone systems established, but some of those which were in existence at the time of the acquisition of the Bell system were subsequently sold to the Government. ${ }_{18} \mathrm{Cf}$. the Manitoba Free Press, Winnipeg, June 3, 1908; The Winnipeg Telegram, June 4, 1908. 
for exceptional consideration were made either directly to the Telephone Department or, more frequently, through a member of the Legislature to the Minister. The Government thus saw themselves in a position of responsibility, and this responsibility having soon become intolerably embarrassing, it became necessary to take further action to throw the nominal responsibility upon the shoulders of the Commission. Therefore, in June, 1908, the Minister of Telephones dispensed with the technical staff which he had employed in the Telephone Department at a cost of $\$ 10,000$ a year, and the power to purchase supplies was transferred to the Commission, the Minister retaining, however, the power of "supervision." 19 Thus this administrative change was essentially a change in form without a change in substance, for so long as the Minister retained "supervisory" powers the Commission could not be free from political influence. As a matter of fact, the chief result of this change in the form of admin. istration was to enable members of the Government to reply to inconvenient claims and complaints to the effect that the patronage had passed out of their hands into those of the Commission, while it still remained open to the Government to bring pressure to bear upon the Commission in order that political interests might be adequately served.

${ }^{19}$ The Manitoba Free Press, Winnipeg, June 13, r9o8. Cf. Order-in-Council No. Izorr.
While the Telephone Commission was doing its best - under pressure - to carry out the Government's policy in regard to the rapid extension of the telephone system (a policy dictated solely by political expediency), the Commission could not redeem the pledges in regard to the reduction of rates. In general the Bell rates continued to be retained throughout 1908; in certain cases (some of which have already been mentioned) they were materially increased. ${ }^{20}$ The Opposition newspapers did not cease denouncing the members of the Government for having failed to live up to their promises; but the fault lay in having made the promises rather than in having failed to fulfill them. Had the Government met all the demands of the Opposition - or, indeed, all those of the public - the telephone enterprise would speedily have been reduced to hopeless bankruptcy; even as it was, the credit of the Province had undoubtedly suffered. ${ }^{21}$ The general situation certainly justified the following summary made by an Opposition newspaper toward the close of the first summer of Government operation: "The carrying out of the Government's telephone policy has resulted in the people of Manitoba having had placed upon them an indebtedness of close upon $\$ 4,000,000$. The interest on this indebtedness makes a heavy fixed annual charge. The service is no better than

${ }^{20}$ Cf. the Manitoba Free Press, Winnipeg, August 28, 1908. 21 Cf. the Manitoba Free Press, Winnipeg, September 22, 1908. 
was given by the Bell Telephone Co., whose shareholders now hold the Province's bonds and have to be paid their interest regularly. The rates are no lower than the Bell rates were, in some cases they are higher." 22 The accusations against the Government, however, were disposed of in the most cavalier manner; for example, one of the Cabinet Ministers said quite cynically that "when they engaged in the battle with the Bell Telephone Company, it was necessary to make strong statements" ${ }^{23}$ which is tantamount to a frank avowal that the statements made by the members of the Government during the telephone agitation were made without regard to truth.

\section{SUBSTANTIAL PROFITS FROM THE FIRST YEAR'S}

OPERATIONS ALLEGED BY THE GOVERNMENT

In November I908, when the Government telephones had been in operation for almost a year, a rumour was circulated to the effect that rates would be "cut in half" on January I, 1909, this rumour being based upon a statement of a Cabinet Minister that the Telephone Department, for its first year, would show a profit of $\$ 200,000.2^{24}$ In December

${ }^{22}$ The Manitoba Free Press, Winnipeg, September 22, 1908.

${ }^{23}$ The Manitoba Free Press, Winnipeg, November 16, 1908.

24 Cf. The Minneapolis (Minn.) Journal, November 14, I908; The Detroit News Tribune, November 15, 1908; the New York Tribune, November $16,1908$.
I9o8, Winnipeg and other papers contained repeated announcements "on reliable authority" that the first year of Government telephone operation had been so successful that there would be a profit of $\$ 200,000,{ }^{25} \$ 225,000,{ }^{26}$ or $\$ 250,000 .{ }^{27}$ Again, in January 1909, a Cabinet Minister took credit to the Government for the alleged profit and announced that "with such a showing there is no doubt that we will reduce rates." 28 That these press statements were inspired by the Government is shown by the fact that similar claims were made at about the same time by members of the Government in election speeches; and such statements were employed widely to induce a belief in the success of the Manitoba telephone venture, and in the absence of proof to the contrary they were accepted in good faith.

The session of the Manitoba Legislature at which the first report of the telephone service was presented, began on February 4, 1909. The extent to which the telephone was regarded as a political issue is illustrated in the statement of the Government program which opened the session, for of the four paragraphs comprising this statement, the telephone question occupied two. In one paragraph it was announced that "a most substantial surplus has been

25 Cf. Telephony, Chicago, December 19, 1908.

26 Cf. The Tribune, Winnipeg, December 25, 1908.

27 Cf. The Tribune, Winnipeg, February 4, 1909.

28 The Manitoba Free Press, Winnipeg, January 5, r9og. 
obtained." ${ }^{29}$ A few days later a discussion of the telephone question was introduced by an Oppositon member and a vigorous debate ensued, in the course of which one speaker said that "he suggested that members should tell the Government what was wanted in the constituencies. Since he had been a member . . . he had always laid his case before the Minister of Public Works and had benefited by so doing. Every member should do the same, not only to the Minister of Public Works, but to every department." 30 In other words, the exertion of political pressure at any point in the Government would produce the desired results!

When a telephone profit was announced by the Government, of course its often repeated promise that service would be provided " at cost" ${ }^{31}$ was recalled, and the Opposition newspapers began to demand " rebate cheques for telephonę users." 32 But although members of the Government, in pre-election statements, had insisted that a profit of $\$ 200,000$ had been produced the first year, the Public Accounts of the Province, when they were placed before the Legislature on February I I, I909, failed to confirm these pre-election announcements, but showed a

\footnotetext{
29 Journals of the Legislative Assembly of Manitoba, Session Igog, pp. I-2. Cf. The Winnipeg Telegram, February 4, I909.

${ }^{30}$ The Winnipeg Telegram, February ro, 1909.

31 Cf. p. 18, supra.

32 Cf. the Manitoba Free Press, Winnipeg, February I1, 1909, and February 12, 1909.
}

"balance" from the year's telephone operation of only $\$ 168,9 \mathrm{I} 5$, as follows: ${ }^{33}$

Receipts: Telephone rentals ...

$\$ 656,486.74$

Disbursements :

Paid to Telephone Commission ........... \$300,000.00

Expenses of Telephone Department ............

$19,319.33$

Interest:

Debentures-Series H. 32,020.00

Debentures-Series I... $136,231.67 \$ 487,571.00$

Balance $\$ 168,915.74$

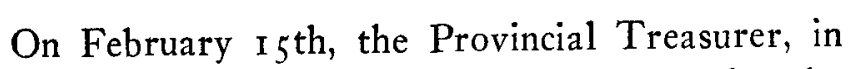
explaining his budget for the year 1909 , said that the Government confidently believed that its telephone policy was sound and that it was giving " a service that was equally as cheap as similar services are being given elsewhere." No reference was made to the fact that this opinion as to the cheapness of the service was not the view which had been presented by members of the Government in regard to the rates prior to the acquisition of the system,- rates which had not been reduced by the Government. The Provincial Treasurer also declared that since only a small proportion of the population of Manitoba were telephone users, whereas the whole population

${ }^{33}$ Sessional Papers. Legislative Assembly of Manitoba. Session 1909, pp. III, 355-357. 
had become responsible for the debt on the telephone account, the excess of revenue over expenditure should go into the general exchequer of the Province. $^{34}$ He failed to observe, though, that this position was quite inconsistent with the Government's promise to provide telephones "at cost." ${ }^{35}$

The Opposition press was not slow in detecting the peculiar system of accounting, or rather the lack of proper accounting, as a result of which this apparent surplus of $\$ 168,9$ I 5 made its appearance. For example, it was shown that the current expenses of the Commission during the year $(\$ 300,000)$ amounted to only 46 per cent. of the gross receipts, whereas under the Bell Company during the ten years $1895^{-1904}$ the annual percentage of operating and maintenance expenses to gross receipts had averaged 7 I per cent., so that it appeared that the Government had really charged practically all maintenance expenses to plant account. The Manitoba Free Press pointed out that if all maintenance expenses had been charged against revenue and if combined operating and maintenance expenses had consumed only 70 per cent. of gross receipts, then this "surplus" of \$168,915 would have almost disappeared; and the Free Press naturally concluded that if the Government, to "save its face," should reduce the rates, it would "involve the Prov-

${ }^{34}$ The Winnipeg Telegram, February 16, 1909.

${ }^{35}$ Cf. p. 18, supra. ince in heavy financial loss." 36 However, even the re-statement of the accounts made by the Free Press included no charge for accrued depreciation.

The accounts of the Telephone Department were issued a few days after the Public Accounts had been presented to the Legislature. ${ }^{37}$ The component items of these accounts did not agree with those given in the Public Accounts, since - for example - the gross revenue included a large amount of unearned rentals; but the accounts disclosed no materially different state of affairs, though by making allowances for unearned rentals and for accrued depreciation the Opposition press was able to argue that the real result of the year's operations was a deficit of about $\$ 30,000$. $^{38}$

REAL DEFICIT IN I9O8 CONCEALED BY UNSOUND ACCOUNTING METHODS

Although it is true that the telephone accounts for 1908 as given both by the Provincial Treasurer and by the Telephone Department were character. ized by a total lack of the elementary principles of commercial accounting, the revisions of the accounts made by the Opposition were also unscientific and cannot be accepted as accurate representations of the true situation. In order to arrive at any approx-

\footnotetext{
36 The Manitoba Free Press, Winnipeg, February 16, 1909.

37 The Winnipeg Telegram, February 23, 1909.

38 The Manitoba Free Press, Winnipeg, February 24, 1909.
} 
imation of the real financial results of Government telephone operation, it will be necessary to recast the accounts of the system so that they will accord with accounting methods which are recognized to be sound. From the stand-point of sound accounting practice, the accounting methods employed by the Government were obviously deficient in two respects :

(a) A considerable portion of the maintenance expenses were charged to capital (instead of being charged against revenue) ;

(b) No reserve was set aside to meet the reconstruction expenses arising from the inevitable constant depreciation of the plant.

In order to eliminate the effects of these deficiencies upon the published accounts, the following procedure has been adopted here:

(a) The amount of maintenance expenses which were improperly charged to capital in the telephone accounts was adjudged, according to an appraisal of the plant made in 1915,39 to reach in the aggregate to $\$ 336,232$, all of which sum was found to have been charged to capital during the first three years of Government operation: 1908, I909 and I910. Although it is impossible to apportion this sum among the three years accurately, yet it is not unreasonable to assume that the greater part of it - say 80 per cent.-was charged to capital during 1908 and

\footnotetext{
${ }^{39}$ Cf. pp. 151-x 52, infra.
}

1909. In recasting the accounts in these pages, therefore, 40 per cent. has been allocated to the year 1908, 40 per cent. to 1909 , and 20 per cent. to I910; that is to say, sums representing these percentages of $\$ 33^{6,232}$ have been deducted from the plant account and have been added to the current expenses for "Maintenance " in the respective years.

(b) As has already been observed, ${ }^{40}$ the Telephone Commission had pointed out that in order to provide an adequate reserve to meet the reconstruction expenses arising from constantly accruing depreciation, a sum equivalent to at least 6 per cent. of plant cost should be set aside from current revenue each year. In view of the fact that the climatic conditions in Manitoba are such as to cause abnormally rapid deterioration in out-door plant, ${ }^{41}$ it is certain that no less a sum would have been sufficient to provide an adequate reserve; and in recommending that such a sum be set aside, the Telephone Commissioners - as they themselves did not fail to point out were understating rather than overstating the amount of depreciation reserve which the best telephone engineering experience had found to be necessary. ${ }^{42}$

40 Cf. p. 41, supra.

41 Reference to the effect of the "extraordinary weather conditions" in Manitoba upon the life of the plant may be found in the Seventh Annual Report of the Manitoba Government Telephones for the Fiscal Year ending November 30th, 1914, p. 14. Cf. p. 140, infra.

42 For example, in a letter to the Minister of Public Works, dated April I9, rgrr, the Chairman of the Telephone Commission said that the telephone plant "should have an annual reserve set aside to 
But the Government refused to allow the Commission to set aside any depreciation reserve to meet reconstruction expenditure, and thus forced the Commission to adopt the unsound and hand-to-mouth policy of charging reconstruction expenses each year directly against current revenue; as a result, during the first four years of Government operation reconstruction expenses were included with maintenance expenses in the telephone accounts. Therefore, in recasting the accounts, it is necessary to include with each year's current expenses an amount equivalent to 6 per cent. of the cost of the plant; ${ }^{43}$ and on the other hand, it is necessary to exclude from each year's current expenses the expenses of the reconstruction actually effected during the year, as expenses for reconstruction should properly be met from depreciation reserve. In regard to the latter process - the exclusion of actual reconstruction expenses from current expenses - unfortunately during each of the first four years of Government operation (1908-19I I inclusive) it is impossible to determine

provide for its replacement of at least $6 \%$, assuming it is to earn interest. All authorities agree that the average life of a well built telephone plant is twelve years, or an annual depreciation at the rate of $8 \%$."

43 The cost of the plant, as used in this work, represents each year the cost at the end of the preceding year, as derived from the annual accounts of the Government telephone system given in the Sessional Papers. All intangible items and all current expenses improperly charged to capital, as shown by an appraisal of the plant made in 1915, are excluded. Cf. pp. 151-152, infra. from the published accounts the exact amount of the actual reconstruction expenses, owing to the fact (mentioned above) that the expenditure for maintenance and the expenditure for reconstruction were combined into one item of "Maintenance" each year and were not shown separately. However, by assuming each year that the portion of these combined expenditures (including the maintenance expenses deducted from plant account as explained above) which was in excess of a reasonable allowance for maintenance expenditure represented reconstruction expenditure, an approximation of actual reconstruction expenses may be obtained. Accordingly, in recasting the accounts for the first four years, maintenance has been assumed to have required each year an amount which bore the same relation to the cost of the plant as did the amount of the maintenance expenses in those years in which maintenance expenditure is shown as a separate item in the accounts; and the balance of the combined maintenance and reconstruction expenditures in these four years has therefore been excluded from current expenses as representing reconstruction expenditure.

By eliminating the deficiencies in the accounting methods employed by the Government and by recasting the published accounts in the manner described, the financial result of the first year of Government operation appears as follows: 
Gross Revenue .........

$\$ 656,487$

Expenses:

Operation $\ldots \ldots \ldots \ldots \ldots \$ 256,129^{*}$

Maintenance $\ldots \ldots \ldots \ldots .94,162$

Depreciation ......... I 49,860

Total Expenses ......

500,151

I 56,336

Net Earnings .............

168,252

Interest $\ldots \ldots \ldots \ldots \ldots \ldots$

$\$ 11,916$

* This figure is necessarily estimated, as operation expenses - in 1908 - are not shown separately in the published accounts. Cf. p. 5I, supra. The figure bears the same ielation to gross revenue, however, as does the average of the actual figures for operation expenses in I909, I9Io, and IgIr. Allowance has been made for operation expenses incurred in 1908, but not included in the telephone accounts until the next year.

This revision of the accounts eliminates the effect of the two known deficiencies in the accounting practice which the Government forced upon the Telephone Commission; but it must not be supposed that these were the only deficiencies in the telephone accounts. An inspection of the books would doubtless reveal departures from sound accounting principles in a considerable number of other cases,some serious, some petty. It should be observed, however, that the effect of all deficiencies in the accounts is to increase the book profits of the system: the tendency of Government bookkeeping is to include with revenue items which should properly be excluded (such as revenue received during the year, but not earned during the year) and to exclude from expenses items which should properly be included (such as the value of work done free of charge by other Government departments). Thus, as regards the preceding revision of the accounts (and the subsequent similar revisions), failure to make allowance for the effect of unknown deficiencies in the accounts merely decreases the losses shown and therefore makes the results conservative. Moreover, the conservatism of the results as stated here is enhanced by the fact that in such revisions of the accounts no deduction from revenue is made to provide for the gradual writing off of intangible capital, although it cannot be open to question that annual provision for writing off intangible capital should have been made; indeed, the necessity for the gradual extinction of intangible capital was later officially recognized. ${ }^{44}$ It is clear from the above revision of the accounts, then, that all profits which had formerly been earned by the Bell Telephone Company - over and above a sum equal to the interest charges paid by the Government on their telephone capital - were entirely dissipated during the very first year of Government operation. Even if less provision against depreciation had been made, this real result would not have been materially affected - and this real result was produced under even higher rates than the Bell Company had charged! ${ }^{45}$

14 Cf. p. 154 , infra.

45 Cf. pp. 42 and 47 , supra. Moreover, the Government system is exempt from practically all taxation, whereas the Bell Company paid almost $\$ r o, \infty 00$ a year in taxes in Winnipeg alone (The Mani- 
On March 9, 1909, the Report of the Public Accounts Committee for the year I908 was brought before the Legislature. The Committee had made a somewhat detailed inquiry into the telephone accounts and had confirmed such significant facts as that the telephone revenue for the year had included unearned revenue and that many current expenses had been charged to capital. Nevertheless, the Committee's report was a purely formal generalization containing no reference to details. ${ }^{46}$ But the Opposition was unwilling to allow the occasion to attack the Government's accounts to go by default and an Opposition member of the Legislature therefore moved the adoption of an amended report which stated the case against the accounts accurately. In this amendment attention was called to the inclusion of unearned revenue with earned revenue; to the existence of large bank overdrafts incurred for telephone expenditures; and to the absence of any provision against depreciacion. ${ }^{47}$ Needless to say, however, this amended report was rejected and the original colorless report adopted. ${ }^{48}$ Nevertheless, the proceedings in connection with this report

toba Free Press, Winnipeg, December 13, 1908, and December 24, 1908). This exemption from taxation is a factor which must be borne in mind throughout the consideration of the financial results of the Government telephones.

4 Journals of the Legislative Assembly of Manitoba, Session 1000, pp. I54-5.

47 Ibid., pp. $155-8$.

48 Ibid., p. 158 . of the Public Accounts Committee show that the Opposition, for political ends, early adopted every means in their power of calling the Government to account for deliberately misleading the people of the Province into the belief that the administration of the telephone system had been financially successful; and although the evidence as to telephones taken on oath by the Public Accounts Committee is not printed, it has already been seen that enough material of an indisputable character remains to prove that the Government administration of the telephones in Manitoba exhibited from the beginning a complete disregard of sound principles of finance.

\section{A MODERATE RATE REDUCTION EFFECTLD BY THE} GOVERNMENT FOR POLITICAL PURPOSES

On February 25, I909, a few days after the publication of the telephone accounts, the Minister of Public Works, speaking before the Legislature, very justly complimented the Telephone Commissioners upon their management of the system, for there can be no doubt that they made the best of highly unfavorable conditions and that, so far as they were concerned, the system was generally managed efficiently and economically; the deficiencies in management lay altogether outside of the sphere of the Commission. In the same speech the Minister stated that the real "surplus" for the first year of operation was $\$ 232,501$, and continued: "In view of the 
magnificent financial results as shown by the financial statement, it becomes my pleasant duty to announce the conclusions reached by the government in respect to a reduction of rates." ${ }^{49}$ He did not say that the Government had been advised by the Telephone Commission that the telephone accounts showed that reductions could be made; he intimated clearly that the reduction of rates was due to the policy of the Government.

The Minister of Public Works then announced the new rate schedule, which applied to exchange rates only, long distance rates remaining unchanged. The chief provisions of the new schedule were as follows:

a) The flat (i.e., unlimited service) rate for individual line, business service in the cities (\$50 per year in Winnipeg) was left unchanged.

b) The other flat rates were reduced as follows:

Winnipeg.

Individual line, residence: existing annual charge of $\$ 30$ reduced to $\$ 25$.

2 Party line, residence: existing annual charge of $\$ 24$ reduced to $\$$ I 8.

Brandon and Portage la Prairie.

Individual line, residence: existing annual charge of $\$ 25$ reduced to $\$ 20$.

${ }^{49}$ The Winnipeg Telegram, February 26, 1909.
2 Party line, residence: existing annual charge of $\$ 2$ I reduced to $\$ 15$.

Small Towns.

Individual line, business: existing annual charge of $\$ 24$ reduced to $\$ 20$.

Individual line, residence: existing annual charge of $\$ 18$ reduced to $\$ 15$.

Farmers' Lines.

Existing annual charge of $\$ 24$ reduced to $\$ 20$.

Existing annual charge of $\$ 30$ reduced to $\$ 25$.

c) A 2 party line, business, unlimited service rate was introduced in the cities; and a measured service rate for individual line business and residence service was introduced in the cities as an alternative to the flat rates for such service.

While the introduction of the measured service rates was an innovation in Manitoba, nevertheless, since the flat rates were retained and the measured rates were merely optional, the innovation was practically unheeded and caused no comment. The new rates were to go into force on April I, I909.

The new schedule was in effect a political scale devised by the Government for the purpose of placating the politically most influential classes. There can be no doubt as to its source, in view of the fol- 
lowing extract from the evidence of the Chairman of the Telephone Commission before the Public Accounts Committee in I9Io. The Chairman, when questioned by a member of the Committee in regard to the reduction of the farmers' rate from $\$ 24$ to $\$ 20$, replied as follows:

"Q. - Was the reduction from $\$ 24$ to $\$ 20$ made by the commission?

"A.- No, we put it in effect, but it was a reduction made by the Government.

"Q.- Were you consulted as to the reduction being made?

"A.- Yes, I was consulted.

"Q.- And did you advise that it should be made?

"A.- I cannot say that I did."

And in another place:

"Q.- And you are sure that the suggestion of the $\$ 20$ rate did not come from you?

"A.- I am sure of that." ${ }_{50}$

No comment is necessary to illuminate this testimony; ${ }^{51}$ it is also self-evident that the reductions

${ }^{5}$ Sessional Papers. Legislative Assembly of Manitoba. Session 1910. Appendix A. Evidence Taken before the Public Accounts Committee during the Session of 1910, p. 703.

51 This evidence, however, is further proof of the situation in regard to the Telephone Commission. There was at the head of the Commission an absolutely honest and upright man who was doing the best he could for the Province, a man technically trained who knew that more or less disastrous failure was inevitable unless a change of policy occurred. On the other side there was the Government, merely desirous of retaining its power and utilizing the telephone system for the purpose of securing party advantages, however temporary and at whatever cost to the Province. provided by the new schedule were insignificant in comparison with the pledge that rates would be "cut in two."

Although the results of the first year's operation of the Government telephone system gave little satisfaction in Manitoba, notwithstanding the "surplus" resulting from the Government's manipulation of the accounts and notwithstanding the reduction in rates, some of the politicians in the Dominion Parliament at Ottawa attempted to make political capital out of the alleged success of the Manitoba Telephones. In the Dominion Parliament on March I, I909, one member moved the adoption of a resolution that "it is the immediate duty of the government to initiate and carry out such measures as will ... secure to the people of Canada, other than the people of Saskatchewan, Alberta and Manitoba, a rate of service at least as moderate as ... prevails in countries where a national telephone service is maintained." 52 In support of his motion the member referred especially to the case of Manitoba, and spoke of the Government Telephones there as having yielded "a surplus of $\$ 380,000$ for the eleven months and a half in which they have been operating." ${ }^{53}$ But on being questioned on this point, the proposer of the resolution admitted that

52 Official Report of the Debates of the House of Commons of the Dominion of Canada. First Session-Eleventh Parliament. Vol. LXXXIX. Column r76r.

53 Ibid., Column I769. 
he had not analyzed this surplus, while another member of Parliament showed that the actual situation in Manitoba was well understood by pointing out that the Government service had produced an actual deficit and continuing: "I am aware that the telephone system is operated by the commission. But I am also aware that, so far as policy is concerned, the commission is under the control of the government, and the revenues received by the commission are paid over to the provincial treasury. The rates are certainly controlled by the government, and not by the commission" since "there was no justification for that reduction, there were no business reasons for it." 54

So much for the events connected with the first year of the Manitoba Government telephones.

\section{LABOR DIFFICULTIES}

The second year of Government operation ( I 909) had scarcely begun before the Telephone Commission encountered some labor difficulties. A desire for economy, as well as the necessity for speed to meet the conditions imposed by the Government in the reduction of the rates for rural telephones and in the policy of rapid construction, induced the Telephone Commission - in April, 1909 - to increase the working day of its line employes from nine to ten hours during the summer season. Although it

54 Ibid., Column 1780 et seq. had been the accepted practice of the Bell Telephone Company to have a ten-hour day during the summer season, those workmen who were paid weekly or monthly wages - about $60 \%$ of the total number employed - immediately resented the increase whon it was adopted by the Commission. The Trades and Labor Council of Winnipeg denounced the Government. "Such action," one of the members said, "would be borne in mind in the next election." 55 Since, however, the Government were being kept in power by the vote of the farmer and not by the vote of the urban artisan, the threat carried no weight. Still, the fact that an administrative change led to a political attack illustrates one of the difficulties encountered by public authorities which engage in industrial enterprises. ${ }^{56}$ It is also worthy of note that in November, 1909, as a protest against the discipline enforced by the Commission, the exchange operators in Winnipeg threatened to strike. ${ }^{57}$

On September I, I909, the Telephone Commission effected a reorganization of the administration of the system, introducing what is known as "functional" organization. The entire business was di-

55 The Manitoba Free Press, Winnipeg, April 16, 1909.

56 That continued employment in the telephone service depended upon political considerations is evident from the fact that, upon his nomination as the Opposition candidate for Killarney (Manitoba) at the next election, the long distance agent of the Government telephones at Ninga was dismissed. The Manitoba Free Press, Winnipeg, July 7, I909.

57 Cf. the Manitoba Free Press, Winnipeg, November 6, 1909. 
vided into three departments, viz., commercial, traffic and plant. The only territorial distinction was between Winnipeg and the rest of the Province. At the head of each department there was placed a superintendent, reporting to the Commission. In speaking of the change, Mr. W. H. Hayes, one of the Telephone Commissioners, said: "All telephone companies are gradually working into this new form of organization; it has proved to be far superior to the old method in facilitating the handling of the business. It arranges for a more detailed supervision of every locality on the system." 58 In view of the generally recognized efficiency of the "functional" type of organization, its early introduction reflects great credit upon the Telephone Commission.

\section{DEFICIT IN I $9 O G$ CONCEALED BY THE ACCOUNTING METHODS PRESCRIBED BY THE GOVERNMENT}

As a result of the deficiencies in the accounting methods prescribed by the Government, the accounts of the telephone system for 1909 , printed in the brief annual report of the Telephone Commissioners, ${ }^{59}$ gave no indication of the real financial outcome of the service during the year. As in 1908, maintenance expenses were charged to capital dur-

58 The Bulletin, Winnipeg, August 21, r9o9.

59 Report of the Commissioners of Government Telephones for the year 1gog. Sessional paper No. 20. Sessional Papers. Legislative Assembly of Manitoba. Session IgIo, pp. 624-627. ing the year and no reserve against depreciation was set aside; moreover, the Commissioners were not able to include in the accounts the interest paid during the year upon the telephone capital, the payment of such interest charges having been specifically reserved to the Provincial Treasurer. ${ }^{60}$ According to the accounts in the report of the Telephone Commissioners, there was an "excess of revenue over expenditure " for the year of $\$ 27$ I,797; but when the effect of the known deficiencies in accounting methods is eliminated in accordance with the procedure already described, ${ }^{61}$ and when the interest upon the telephone capital ${ }^{62}$ has been deducted, the results of the year's operations appear as follows:

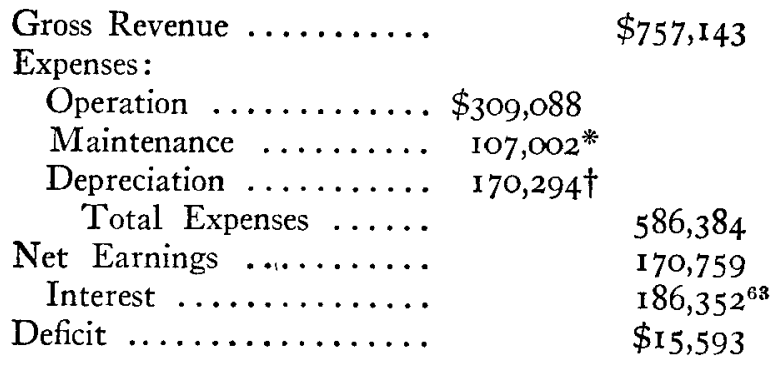

* This figure bears the same relation to plant cost as do maintenance expenses in those years in which maintenance expenditure is shown as a separate item in the accounts.

tEquivalent to $6 \%$ of plant cost at the end of the preceding year.

${ }^{60}$ Cf. p. 72, infra.

61 Cf. pp. 54-57, supra.

62 Until 1913 the annual interest charges upon telephone capital are shown only in the Public Accounts (i.e. the annual reports of the Provincial Treasurer) in the Sessional Papers.

${ }^{63}$ Sessional Papers. Legislative Assembly of Manitoba. Session 1910, p. 52. 
In other words, the Government's accounting methods concealed a real deficit which, although it was equal to only 2 per cent. of the gross revenue, was nevertheless greater than the corresponding deficit in 1908; while the recurrence of a deficit was an ominous sign. Moreover, in thus creating real deficits, the Government was of course compromising the public credit, a fact which an analysis of the Public Accounts of the Province will show. But even if it had been justifiable, as good public policy or as conducive to future advantages, to incur a loss in the telephone enterprise, it would have been only proper for the Government frankly to have stated such losses, instead of endeavoring to conceal them by means of lax and not entirely honest accounting methods. Unfortunately, however, the Manitoba Government from the beginning deliberately refused to look facts in the face; they preferred to deceive the public - and probably themselves - by creating the illusion that their venture into commercial business was a financial success. No illusion could have been greater.

When examined before the Public Accounts Committee in regard to the telephone accounts, the Chairman of the Telephone Commission steadily refused to admit responsibility for the manner in which the accounts had been presented. He said that he was obliged to hand over to the Government all sums received by him, and to draw from the Government, or from the bank on the credit of the Government, all sums required by the Commission for the conduct of its business. The following evidence of the Chairman before the Committee shows conclusively that the responsibility lay entirely with the Government:

"Q.- Has the Commission, within the years that they have been operating the telephone system, set apart any sum whatever for sinking fund purposes?

"A.- We have nothing to do with that.

"Q.- Has the Commission set anything apart for that?

"A.- We pay every cent we get to the Provincial Treasurer and don't set apart anything.

"Q.- Then you can answer the question negatively, the Commission has set apart no sum whatever for sinking fund purposes out of the earnings of these two years?

"A.- No, we have not.

"Q.- Has your opinion ever been asked upon that, whether it would not be a good business to do so?

"A.- No.

"Q.- That is left entirely to the Government?

"A.- Yes, that is left entirely to the Government.

"Q.- Has the Commission set apart or recommended the setting apart of any sum for deprecia- 
tion or a contingency account or anything of that kind?

"A.-Well, the same answer applies to that question. ...

"Q. - What profit did the Government telephones earn in 1909 , do you remember?

"A.-We do not deal with the matter of inter: est on debentures at all; we remitted some $\$ 775$, ooo to the Provincial Treasurer, and have received from him $\$ 485,000$.

"Q.-Then the Commission, as such, does not know what amounts were paid out for interest on debentures?

"A.- No.

"Q.- Then the Commission, as such, is unable to show by their statement at what profit or loss the business is being conducted?

"A.-We can show the difference between the actual cost of operating and maintenance, and the amount of revenue.

"Q.- And that is what you purport to show?

"A.- That is all we can show." 64

In regard to rates, another passage from the evidence of the Chairman of the Telephone Commission, referring to the reduction in rates, is significant :

64 Sessional Papers. Legislative Assembly of Manitoba. Session 1910. Appendix A. Evidence Taken before the Public Accounts Committee during the Session of 1910, pp. 706-7.
" Q.- As far as the farmers' rates are concerned, I believe your view was that $\$ 20$ (i.e., the reduced rate) was too near the cost without leaving anything for profit?

"A.- That is right.

"Q.- You never suggested that the farmer should get the benefit of anything that was coming in that direction?

"A. - Well, the recommendation came from the Government to reduce the rates on the rural lines." 65

And that the Government fully intended to take the credit with the farmer, is shown by the following passage:

"Question (by Dr. Armstrong, a member of the Committee). - Have any suggestions been made by the Commission to the Government to restore the price back to $\$ 24$ a year for farmers' telephones?

"A.- I would like to."

The Attorney-General here interposed: "No doubt he would like to, and no doubt Dr. Armstrong would like to charge the farmer more, but we do not propose to do so." 60

These extracts from the evidence given on oath by the Chairman of the Commission in regard to the telephone accounts and rates are further proof of the pervasive character of the Government con-

65 Ibid., p. 7 14.

${ }^{66}$ Sessional Papers. Legislative Assembly of Manitoba. Session 1010. Appendix A. Evidence Taken before the Public Accounts Committee during the Session of 1910, p. 712. 
trol of the Telephone Commission. They show that the Commission had in effect to do what it was told to do by the Government. It was forced against its desire to reduce the rates on rural telephones; the mere suggestion that these rates should be increased was met with a contemptuous negative by the Attorney-General.

When the Report of this Public Accounts Committee was presented to the Legislature on March 16, 1910, an Opposition member moved that the Report be referred back to the Committee for amendment in order to insert, among others, the following paragraphs: ${ }^{67}$

"That the evidence of the Provincial Auditor shows that the trust accounts of the Province are not audited by him." (The funds which are appropriated for telephone construction purposes constitute trust funds. Large sums had therefore been disbursed by the Government officials without effective audit.)

"That, since the first day of May, I909, the Telephone accounts have not been audited by the Provincial Auditor, the same having been removed from his jurisdiction by the action of the Executive." (The result of this action of the Government was an inadequate audit which gave rise to some of the abuses which were revealed later.)

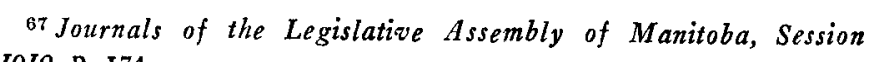
I9ro, P. 174.
On a party vote these proposed amendments to the Report were rejected..$^{68}$

CONSTRUCTION POLICY OF THE GOVERNMENT INECONOMICAL AND MARKED BY POLITICAL ABUSES

The year I9Io was the third year of the operation of the Government telephones and, in methods and results, it was not distinguished in any essential from its two predecessors. At the end of the year the system embraced 29,748 telephones, distributed as follows:

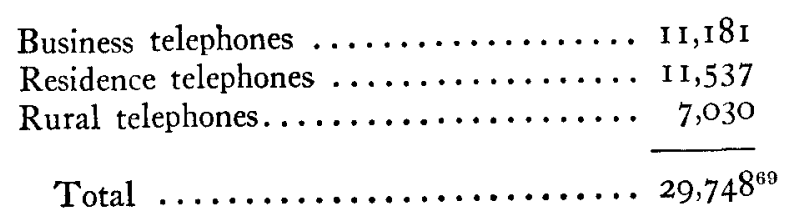

As the number of telephones at the time of the Government's acquisition of the system was $14,042,7^{70}$ the number of telephones had been doubled in the three years of Government operation. In spite of the fact that this increase was secured at an excessive cost to the Province, and although there was no real economic demand for some of the extensions which had been effected, the growth of the service

${ }^{68}$ Journals of the Legislative Assembly of Manitoba, Session 1910, p. 175 .

69 Repart of the Commissioners of Manitoba Government Telephones for the year ending 3rst of December, 19ro. Sessional Paper No. 14. Sessional Papers. Legislative Assembly of Manitoba. Session IOII, p. 582.

${ }^{70}$ Cf. p. 28, supra. 


\section{6}

\section{GOVERNMENT TELEPHONES}

has certainly been the most unobjectionable feature of the history of the system under Government control. However, as will be pointed out in detail later, ${ }^{71}$ it must not be assumed that this growth was due to Government control, for no such assumption can have any basis in fact. Incidentally, it will be recalled that the number of telephones was doubled during the last two years of Bell management and that the Bell Company had anticipated a much larger growth in the following years; indeed, the large amount of advance construction at the time of the acquisition of the Bell system was put forward by the Government as one explanation of the apparently high price paid for the plant. ${ }^{72}$

Moreover, the Manitoba Free Press reported an example of the political abuses which were rampant even in the matter of extensions. Although it is impossible at this date to verify the incident which the Free Press relates, yet it seems so probable that it is given here:

"The people of Woodridge and the region surrounding that station ... a are suffering from the sort of hope deferred which maketh the heart sick, in the matter of securing telephone connections.

"In the closing days of last June, just before the recent provincial general elections, several carloads of poles were unloaded at Woodridge, and it was announced that the work of connecting up Woodridge with the provincial government's long distance telephone system would be gone on with immediately after the elections.

"A number of voters were engaged, at the rate of $\$ 6$ per day per man and team, to do the work of taking the poles out to the point to which it was stated the trunk telephone line would be completed in a week or two.

"The Woodridge district is partly in the constituency of Emerson and partly in the constituency of Carillon. It is a predominantly Opposition district.

"Within two weeks after the elections, a train of empty cars came along and gathered up all the telephone poles and brought them to Winnipeg again." 73

The Free Press refers editorially to the incident as a case of "fishing for votes with telephone poles." 74

In Igro, the Government's policy of rapid construction did not take into account the state of the labor market, with the result that the Commission found it impossible to secure an adequate supply of experienced men fully to carry out that policy. In consequence, a number of rural and long distance lines had to be abandoned in the course of construc-

73 The Manitoba Free Press, Winnipeg, October 8, I910. 74 Ibid. 
tion and were unable to be completed until the season of 19 Ir. $^{75}$

\section{FINANCIAL RESULT IN I9IO AGAIN AN APPARENT PROFIT BUT A REAL LOSS}

The telephone accounts for I9 Io were again practically meaningless. Although without doubt fewer maintenance expenses were charged to capital in I 9 ro than had been so charged in 1908 and 1909, nevertheless the amount of maintenance improperly charged to capital was considerable even in I9Io. According to the accounts of the Telephone Commission there was an excess of revenue over expenditure of about $\$ 350,000$; $^{\text {i6 }}$ but the Commission was still without authority to set aside any reserve against depreciation, and their accounts did not - and could not - include the interest paid upon the telephone capital. If (I) all maintenance expenses had been properly charged against revenue, if (2) a reserve against depreciation had been included in current expenses and expenditures for reconstruction had been excluded from current expenses, and if (3) interest on telephone capital had been shown, the accounts for I9 Io would have stood as follows: ${ }^{77}$

${ }^{75}$ Report of the Commissioners of Manitoba Government Telephones for the year ending 3Ist of December, 1910. Sessional Paper No. 14. Sessional Papers. Legislative Assembly of Manitoba. Session IoII, p. 583 .

${ }^{70}$ lbid, pp. $587-590$.

77 For details of this revision of the accounts, see pp. 54-57, supra.
Gross Revenue $\ldots \ldots \ldots \ldots$

$\$ 982,636$

Expenses:

Operation $\ldots \ldots \ldots \ldots \ldots \$ 418,999$

Maintenance ......... I35,316*

Depreciation .......... 215,357

Total Expenses .......

769,672

212,964

$278,500^{78}$

Net Earnings $\ldots \ldots \ldots \ldots$

$\$ 65,536$

Deficit ................

* This figure bears the same relation to plant cost as do maintenance expenses in those years in which maintenance expenditure is shown as a separate item in the accounts.

+ Equivalent to $6 \%$ of plant cost at the end of the preceding year.

Behind apparent profits, therefore, there was a real loss during the year of $\$ 65,000$. Moreover, it is obvious that in the absence of a depreciation reserve even apparent profits (after the deduction of the proper interest charges) could be maintained only so long as the actual reconstruction expenses each year were considerably less than the annual amount which would have been required to provide an adequate reserve against depreciation - either naturally less because of the comparative newness of the greater part of the plant or artificially less because of neglect of necessary reconstruction and failure to keep the plant up to standard. For three years the Government had succeeded in concealing

${ }^{78}$ Sessional Papers. Legislative Assembly of Manitoba. Session roII, p. 57. The interest accounts for the year 19xo are very obscure, but a thorough study of all factors indicates that $\$ 278,500$ is the amount of interest properly chargeable to telephone revenue for the year. 
the truth, but in I9I I, the fourth year of operation, the bubble of fictitious profits burst.

When, after three years, the Government continued to show no sign of adopting, or allowing the adoption of, any sort of commercial accounting, the Telephone Commissioners naturally became very uneasy. They were well aware that the surpluses which the Government had announced were wholly fictitious and that the accumulation of real deficits must eventually be disclosed, involving the Commission as well as the Government in the discredit consequent upon the disclosure. The fact that the Government were primarily responsible would not save the Commission. It was necessary that some drastic measure be adopted in order to bring the true state of affairs openly before the public so that the Government would be forced to take remedial action. No mere representations to the Government would have sufficed; the members of the Government had shown a persistent disregard of the facts - they would not even read the reports submitted to them from time to time by the Telephone Commission. The plain fact is that the members of the Government were wholly occupied in the petty technique of party political management, with the sole purpose of keeping themselves in power; they were at once unable and unwilling to devote themselves to the task of comprehending the intricacies of the business the control of which they had, for political purposes, assumed. Even at that late date, the Government might have greatly ameliorated the situation by frankly confessing that they had made three great mistakes, viz., the unnecessary and ineconomical haste with which construction, especially of rural lines, had been pushed, the failure to provide a reserve against depreciation, and the reduction of the telephone rates. But such a confession, being politically inexpedient, was not made.

FICTITIOUS PROFITS DISAPPEAR IN I 9 I I ; AN AGGREGATE LOSS OF OVER $\$ 300,000$

The Telephone Commissioners could not go upon the public platform and denounce the Government for maladministration of the telephone finances, nor could they utilize the press for purposes of propaganda. There was, however, open to the Commission one course which would inevitably force action - and this course the Commission took. What they did was to expend in I9I I what they conceived to be necessary to bring the plant fully or nearly up to a reasonable standard, and to charge all maintenance and reconstruction expenses against rev. enue. $^{\text {99 }}$ No methods of bookkeeping could conceal the inevitable deficit which resulted - and the Gov-

79 According to the annual reports of the Telephone Commissioners, maintenance and reconstruction expenses amounted to $\$ 282,000$ (including maintenance expenses improperly charged to capital) in rgro and to $\$ 500,000$ in rgrr. Sessional Papers. Legislative Assembly of Manitoba. Session IgIT, p. 589; Session IgI2, p. 534. 
ernment were forced into a position of either meeting this deficit out of the general revenue of the Province or permitting an increase in rates; while at the same time deference to public opinion obliged the Government to abandon their obstinate refusal to provide a depreciation reserve. Thus, by its action, the Commission really rendered a great service to the Province, but a service which eventually proved to be self-sacrifice, for the Government at once began to hunt for a scapegoat upon whom their own sins might be cast.

When the telephone accounts for I9 I w were published, ${ }^{80}$ they showed that, after the deduction of interest charges, ${ }^{81}$ there was a deficit of $\$ 153,000$ on the year's operations. During the year all current expenses were charged against revenue; ${ }^{82}$ but no reserve against depreciation was set aside. Upon recasting the accounts so as to include a depreciation charge and to exclude reconstruction expenses, the real deficit is seen to be even greater; for the plant account had greatly increased during 19 ro and a correspondingly larger depreciation charge was properly required. The recast accounts follow:

${ }^{80}$ Fourth Annual Report of the Commissioners of Manitoba Government Telephones, roII. Sessional Paper No. 25. Sessional Papers. Legislative Assembly of Manitoba. Session IoI2, pp. $534-536$.

81 Sessional Papers. Legislative Assembly of Manitoba. Session IgI2, p. 60 .

82 So far as is known, all current expenses have been charged against revenue in each year subsequent to r9Io. Cf. p. 54, supra.
Gross Revenue...... .

$\$ 1,280,633$

Expenses:

Operation $\ldots \ldots \ldots \ldots \$ 571,916$

Maintenance ....... 21 $8,618^{*}$

Depreciation ........ 347,932

Total Expenses .....

Net Earnings

Deficit

I, I 38,466

142,167

$36 \mathrm{I}, 35^{83}$

$\$ 219,183$

* This figure bears the same relation to plant cost as do maintenance expenses in those years in which maintenance expenditure is shown as a separate item in the accounts.

$\dagger$ Equivalent to $6 \%$ of plant cost at the end of the preceding year.

Inasmuch as care has been taken to understate, rather than exaggerate, these real deficits, there can be no doubt that the losses during the first four years of Government ownership and operation exceeded three hundred thousand dollars!

GOVERNMENT POLICIES RESULT IN EXTRAVAGANCE, INEFFICIENCY AND DISCRIMINATION IN VIOLATION OF PROMISES

Perhaps it might be well to review briefly the chief specific causes of this financial débâcle:

( I) The Government's policy of rapid construction, which was adopted without regard to the ability of the telephone organization to carry it out and was continued in the face of unfavorable labor conditions, forced the Telephone Commission to employ

\footnotetext{
${ }^{83}$ Sessional Papers. Legislative Assembly of Manitoba. Session 1912, p. 60.
} 
men and to keep men on the pay-rolls who would not have been accepted or retained under normal conditions. ${ }^{84}$

(2) The Government's requirement that rural extensions be made in excess of the real demand therefor, also necessitated the construction of lines with one subscriber per mile instead of with an adequate number of subscribers per mile. ${ }^{85}$

(3) The Government compelled the Commission to transform toll offices into exchanges before the volume of business (actual or potential) warranted it; and the Government obliged the Commission to provide night and day service at small exchanges where day service only would have sufficed. When requested to do so by sufficiently influential persons the Commission was also forced to give free service between exchanges. ${ }^{\mathrm{se}}$

(4) Not only did the Government interfere in many subtle ways with the conduct of the telephone business and not only did the members of the Provincial Legislature of both parties exert influence upon the Commission to procure favors for their friends, but the people themselves also utilized these and other persons for the purpose of obtaining concessions through political pressure. ${ }^{87}$

(5) The people also took advantage of the Com-

84 Cf. pp. 43 and 44 , supra.

85 Cf. pp. 38-39, supra.

86 Cf. pp. 39 and 43-44, supra.

87 Cf. pp. $39-40,44-45$, 50 and 67 , supra. mission in almost every possible way. One result was that the estimated cost of construction of line plant was nearly always exceeded. In November, IgIr, the Chairman of the Commission stated: "Every mile of rural telephone lines which was estimated would cost us \$1 50 four years ago, we have found by actual experience now costs us $\$ 200 " ; 88$ in some cases the actual cost exceeded the estimated cost by over Ioo per cent. A large part of this excess must be attributed to the extortionate charges of hotel-keepers, liverymen, etc.; such persons habitually charged the Commission much higher prices than they charged other customers, and yet the Commission was bound to employ them either because they had a local monopoly or because they were supporters of the Government and were able to bring influence to bear to have their bills approved. In a memorandum, dated March 25, I9I2, Mr. Horan wrote to the Chairman of the Commission: "It should be brought out in relief that not only have we had to contend with the fact that politics came into the question so much, but apparently a large percentage of hotel-keepers, storekeepers, and liverymen have been hand and glove with our men foremen and others - in cheating the Government. ... It is of course understood that any remarks or suggestions I have made regarding the entry of

88 Interview reported in the Mantoba Free Press, Winnipeg, November 4, I9x. 
politics into the running of the business applies just as much to the one party as to the other, as I do not for a moment mean to say that if the Opposition were in power they would succeed any more than the present Government in eliminating this unpleasant feature from the business." 89

(6) The reduction in rates made by the Government was obviously unjustifiable and costly.

(7) The Government refused to provide any financial reserve whatsoever, even a reserve against depreciation. ${ }^{90}$

(8) All receipts from the telephone service were handed over to the Provincial Treasury and the Government drew very heavily upon these telephone funds to conduct their decidedly amateurish financial operations, using telephone credits to meet the general expenses of the Province and thus obliging the Commission, both for current and for capital expenditure, to overdraw its bank account to an extent which was, under the circumstances, at once very large and very mischievous. ${ }^{91}$ For instance, on December 3 I, 1909, the overdraft of the Commission at the bank amounted to the considerable sum of $\$ 367,000 .^{92}$ Not only were such methods mani-

80 Memorandum (typewritten), March 25, 19 12.

${ }^{90}$ Cf. pp. $4 \mathbf{1}-42$, supra.

91 Cf. p. 6o, supra.

92 This sum was procured from the bank by the Commission with only oral authorization on the part of the Government. Sessional Papers. Legislative Assembly of Manitoba. Session Igro. Ap- festly inexpedient, but they were also exceedingly expensive for the Commission.

In this connection we may recall the promises of the Government that political considerations would be eliminated from the telephone management and that the service would be self-sustaining.

\section{LONG DISTANCE RATES INCREASED; PROPOSAL TO REVISE EXCHANGE RATES VIOLENTLY AT- \\ TACKED BY THE PUBLIC}

Since the people, in spite of all subterfuges on the part of the Government, continued to hold the Government responsible for telephone conditions, when it was seen (early in I9I I) that an indication of the real financial results of the telephone system would shortly become public property, the Government found itself in a highly vulnerable position; and in order to relieve the Treasury from the financial embarrassment which would necessarily result from having to meet continuous telephone deficits, the Government resolved upon drastic action. It determined to raise the telephone rates, though in doing so it was obliged to repudiate another pledge and to admit that in undertaking to give a telephone service at one-half the Bell rates, it had been altogether wrong.

pendix A. Evidence Taken before the Public Accounts Committee during the Session of 1910, pp. 700-70r. 
The Government's first step in this direction took place in the spring of I9II, when it consented to the Commission's proposal to increase long distance revenue by abolishing the reduced rates for long distance service at night and - in day service - by substituting an initial period of two minutes in place of the existing initial period of three minutes, though retaining the same, or nearly the same, rate for the two-minute period as had been charged for the three-minute period. The rates for each additional minute in excess of the initial period were also raised. The new schedule, which went into effect on May I, I9II, therefore involved a considerable, though indefinite, increase; indeed, the Manitoba Free Press concluded that "the cost of long distance telephoning will be just about doubled." ${ }^{93}$

Then, in November, I9II, the Commission announced to the public that the telephone accounts for that year, when published, would show a loss of $\$ 150,000$ and that the Commission intended to recommend to the Government certain changes in the classification of subscribers. ${ }^{94}$ The proposed schedule of rates, thus presaged in this announcement, was approved by the Government and announced by the Commission on December 1 2, 19 I I ${ }^{95}$ Incidentally, it should be noted that when the reductions were an-

93 The Manitoba Free Press, Winnipeg, April 13, $191 \mathrm{I}$.

$94 \mathrm{Cf}$. Winnipeg newspapers of November 4, I9rr.

$95 \mathrm{Cf}$. Winnipeg newspapers of December I3, I9r. nounced, the Government took upon themselves the task of announcing them, ${ }^{96}$ but that when any increases were to be announced the Government required the Commission to assume the responsibility. ${ }^{97}$

The proposed schedule was as follows: ${ }^{98}$

Winnipeg.

(Installation charge of $\$ 2.50$ on each new line.)

a) Business Service.

Individual line . . \$4 per month, allowing roo calls per month without additional charge; calls in excess of 100, 2 cents each.

Individual Line, Prepayment Service . . . guarantee of minimum revenue of Io cents per day required; each call 5 cents, but a rebate of 2 cents on each call in excess of guaranteed minimum.

b) Residence Service.

Individual line . . \$ $\$ 4$ per month, allowing unlimited service.

Individual line . . \$1.50 per month, allowing 30 calls per month without additional charge; calls in excess of 30,2 cents each.

96 Cf. p. 62, supra.

97 The Government thus paved the way for diverting to the Commission the brunt of the subsequent attack upon the rates.

98 The Winnipeg Telegram, December I3, I9rI. 
Individual Line, Prepayment Service . . . same rate as in the case of business service.

(The radius of the exchange area was increased from two to three miles. Party lines within the exchange area were abolished.)

All Other Exchanges. (i.e., all exchanges except Winnipeg.)

\begin{tabular}{|c|c|c|c|}
\hline \multirow{2}{*}{ No. of Subscribers IN Exchange } & \multicolumn{3}{|c|}{ ANNUAL SUBSCRIPTION } \\
\hline & Business & Residence & Rural \\
\hline 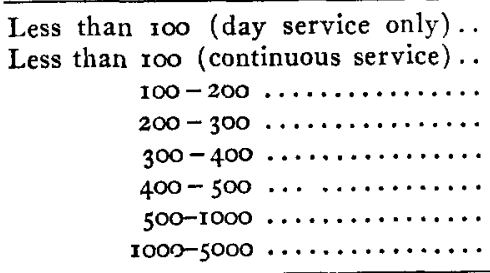 & $\begin{array}{l}\$ 25 \\
31 . \\
31 \\
32 . \\
34 . \\
36 . \\
40 . \\
45\end{array}$ & $\begin{array}{l}\text { \$ } 5 . \\
18 . \\
\text { I8. } \\
19 . \\
21 . \\
23 . \\
24 . \\
27 .\end{array}$ & $\begin{array}{l}\$ 20 . \\
25 . \\
25 . \\
26 . \\
27 . \\
29 . \\
31 . \\
36 .\end{array}$ \\
\hline
\end{tabular}

Ten per cent. discount for prompt payment of six months' subscription in advance.

The proposed rates were to apply, from April I, I912, to all subscribers and from January I, I9 I 2, to new subscribers. As may be seen, the schedule made the measured rate system compulsory (instead of optional) for business service in Winnipeg; it abolished all flat rates in Winnipeg except for individual line residence service (the rate for which was increased from $\$ 25$ to $\$ 48$ per year); and it increased the flat rates in small towns and in rural districts in almost every case.
The reasons for the proposed adoption of an obligatory measured rate system in Winnipeg were thus explained by the Chairman of the Telephone Commission in a statement to the press:

"The number of calls per subscriber (in Winnipeg) is more than double that in the cities of Great Britain, Germany, Australia, and the United States, where measured service is now fully developed. This indiscriminate use of the telephone not only produces congestion, but is primarily the first cause for any poor service that may be experienced by the subscriber. It is this waste of 100,000 calls a day that has led the Telephone Commission to recommend to the government that measured service for Winnipeg can be introduced under conditions that will make the telephone even more reasonable in price than it is under the flat rate. It will reduce the cost of operation to a very large extent, provide a better service, and will be so regulated that the heavy users will pay for the service they receive and not, as in the past, have such service paid for by the small user." 99

Although this application of the measured service principle of rate-making was, under the circumstances, technically justifiable, yet events showed that at the time it was announced it was a tactical blunder. An increase of the rates for unlimited service, to which the people were accustomed, would with-

${ }^{93}$ The Winnipeg Telegram, December 13, Igrr. 
out doubt have aroused opposition; but the strength of such opposition could hardly have been so great as that which the novelty of compulsory measured service actually encountered. Moreover, the novelty of the proposal served to focus public discussion and agitation upon the rates themselves, while the causes underlying the rates were obscured. Thus in Winnipeg an essentially false issue was raised.

Immediately upon the announcement of the proposed schedule (December I2, I9II), a storm of disapproval swept over the Province. ${ }^{1}$ Public meetings of protest were held. Petitions of remonstrance were circulated. Business men welcomed opportunities to give their views for publication and expressed their indignation vociferously. The Opposition and the independent press were swamped with vibrating letters from outraged subscribers. Ardent supporters of the Government were unable to restrain their wrath. The vitriolic outbursts of irate citizens nearly exhausted the supply of condemnatory epithets and adjectives. "Outrageous," " ridiculous," " impossible," "preposterous," " outlandish," " absurd," " nonsensical," " unreasonable," and "extortionate" were among the many kindred terms which were applied to the proposed rates. Even the Telephone Commissioners did not escape the torrent of denunciation and abuse with which the

$1 \mathrm{Cf}$. contemporary Manitoba press.
Government was deluged. In addition, many bitter complaints were made as to the quality of the service, which was frequently compared - unfavorably - with the service under the Bell Company; indeed, one of the arguments advanced by the Chairman of the Commission in defence of the proposed schedule was to the effect that the adoption of measured service rates would greatly improve the quality of the service - a virtual admission that the service had deteriorated under Government control. Many manifest instances of inefficiency and extravagance were also pointed out in the public press. For present purposes it will suffice to dismiss this destructive criticism with merely calling attention to the selfevident fact that the complaint as to "exorbitant" rates in the days of the Bell Company was insignificant in comparison with this popular attack on the schedule prepared by the Commission.

The business men of Winnipeg, however, did not confine themselves to destructive criticism; a number of commercial associations endeavored to offer some constructive criticism in regard to the local rates. For instance, on December ${ }_{3} 3, I_{9} I_{1}$, the directors of the Industrial Bureau of Winnipeg appointed a committee to discuss "the increase of telephone rates with the authorities of the province"; and on December I9th, the Winnipeg Board of Trade also appointed a committee to inquire into the telephone situation. These two committees pro- 
ceeded to cooperate, though they rendered separate reports. Both committees condemned the failure to provide any reserve against depreciation and both called attention to the prejudicial effect of revenue resulting from the unwarranted reduction of the residence rate in I909. Both committees found operating expenses unduly high - though neither was able to explain why ${ }^{2}$ - and both concluded that considerable economies in expenses could be effected. In view of the increased expenses, both committees recognized the necessity for an increase in revenue. However, in suggesting rate schedules which, in their opinions, would provide the additional revenue required, the committees were not in agreement: the Board of Trade committee and Mr. Christie of the Industrial Bureau committee recommended flat rates only, while Mr. Piper of the Industrial Bureau committee favored measured service in addition to unlimited service. On the other hand, both committees were unanimous in urging the use of two and four party lines. ${ }^{3}$

Some of the critics of the Government - notably the Manitoba Free Press - continued to attribute the failure of the telephone enterprise to the price paid for the plant acquired from the Bell Company,

2 These committees did not deal with the question of the relation of the Government to the Telephone Commission.

${ }^{3}$ Report of A Citizens' Committee of Inquiry as to Local Telephone Rates. The Winnipeg Industrial Bureau, March 26, 1912. Report of the Telephone Committee, The Winnipeg Board of Trade, March 26, $19 \times 2$. alleging that the price was excessive. The defence of the purchase price which the Government made at the time, however, is certainly very convincing. It will be remembered that the Government contended that the reasonableness of the purchase price would be proved by consideration of such factors as that the plant purchased included much advance construction, that the Bell Company accepted payment in Provincial bonds at par, that the alternative to purchase was costly and precarious competition, that an allowance was properly made for forced sale, and that there were other legitimate intangibles. ${ }^{4}$ Nevertheless, even assuming that the purchase price was excessive, its financial failure cannot be ascribed to that cause. The margin between success and failure was not so small that a reduction of even as much as $\$ 50,000$ a year in interest charges would have served to turn the scales, for the real deficit in 19 I I was over $\$ 200,000 ;^{5}$ and any argument that the rates had to be raised as a result of the burden of an excessive purchase price, cannot be held as valid. ${ }^{6}$

4 Cf. pp. 29-3r, supra.

5 Cf. pp. $81-83$, supra.

6 Vague suggestions were made about corruption in connection with the purchase. However, not only has no specific charge been made against any one, but the circumstances of the time seem to preclude the possibility of any corruption having existed in that con- 


\section{APPOINTMENT OF A ROYAL COMMISSION, UNDER THE}

CONTROL OF THE GOVERNMENT, TO INVESTI-

GATE THE TELEPHONE COMMISSION

In replying to the critics of the proposed rate schedule, the members of the Government endeavored to divert the entire attack to the Telephone Commission. They admitted that they knew nothing about telephones and stated that they had assented to the new schedule with great reluctance, and only upon the urgent advice of the Commission, to which they gave a clean bill of health as being composed of competent and efficient telephone specialists. $^{7}$ The whole responsibility lay with the Commission, they said; the Government had merely endorsed what the Commission, with its technical knowledge, had seen fit to prepare. So great was the violence of the attack, however, that the Government were forced, in self-protection, to adopt some more plausible means of appeasing public indignation. Accordingly, by an order-in-council dated the thirtieth of January, I9I2, the Government appointed a Royal Commission of Inquiry, composed of Mr. Justice Locke of the Manitoba bench, Mr. G. R. Crowe of Winnipeg and Mr. R. L.

7 For example, on January 4, 1912, the Premier said: "We have implicit faith in our (telephone) commissioners. We believe they are honest, capable men, loyal to the interests entrusted to them." The Tribune, Winnipeg, January 5, I9I2.
Barry of Minneapolis. ${ }^{8}$ This Royal Commission appointed a Counsel, a Secretary, and a firm of accountants to aid in the examination of the accounts, and began its proceedings on February 2, I9I2. The Commission held sessions at Winnipeg and at various places throughout the Province, and inspected the telephone plants at St. Paul and Minneapolis (Minn.), La Crosse (Wis.), and Chicago (III.) ; 234 witnesses were examined and 7080 folios of evidence were obtained, at a total cost of $\$ 22,-$ ooo. ${ }^{9}$ The final Report of the Commission was dated May 20, I9I2, but was not made public by the Government until June $14 \cdot{ }^{10}$

Almost at the outset of their final Report, the Royal Commission made this extraordinary admission:

${ }^{8}$ Interim Report. Sessional Paper No. 19. Sessional Papers. Legislative Assembly of Manitoba. Session Ig12, pp. 508-9. The shrewd politicians comprising the Government went through the ceremony of having the Telephone Commission formally request the Government for the appointment of the investigating committee, whereupon the Government formally consented to the request. (Cf. the Manitoba Free Press, Winnipeg, January r1, 1912.) In spite of this elaborate pretense-which was typical of the subterfuges habitually practised by the Government - there can be no doubt that the initiative in the matter was taken by the Government. Certainly the Government carefully reserved to itself the right of determining the scope of the inquiry, which, as will be seen, was the allimportant factor.

${ }^{9}$ The Manitoba Free Press, Winnipeg, June It, 19x2. This evidence was not published by the Government. The only form in which it exists is in the typewritten copies of the Stenographic Report.

${ }^{10}$ The Report of the Royal Commission was published only in the newspapers; e.g., the Manitoba Free Press, Winnipeg, June $\mathbf{1}_{4}$, IgI2. 


\section{GOVERNMENT TELEPHONES}

"A rather remarkable incident of the sessions of Winnipeg, in view of the deep interest undoubtedly taken by the public in the question, was the almost complete absence of volunteer evidence, a small delegation from Binscarth and one citizen of Winnipeg being the only volunteer evidence that was brought before your Commissioners at the Winnipeg Sessions. . . A At the meetings throughout the country there was invariably a very large attendance of the public. The Winnipeg Sessions were characterized by almost absolute indifference on the part of the public, as indicated by non-attendance." 11

This phenomenon of public indifference in Winnipeg deserves analysis. Although without doubt it was partly due to the volatile character of the community, yet it suggests two further explanations which are not inconsistent and are therefore probably both applicable. The first explanation lies in the habit of leaning upon the Government which is observable in communities of the type to which Manitoba belongs, - a habit which results in feverish anxiety to get the Government to deal with a matter, followed by complete relaxation of interest as soon as the Government undertakes to deal with it. This habit was apparent at the time of the acquisition of the telephone system and its recurrence is not strange.

But another explanation is equally valid, namely,

${ }^{11}$ Report of the Royal Commission.
UNDER FIRST COMMISSION

a distrust of the good faith of the investigating Commission; for an analysis of the powers conferred upon the Royal Commission by the Government discloses the fact that the Commission was authorized to investigate only the acts of the Telephone Commission. The relation of the Government to the telephone enterprise was therefore inferentially excluded from the scope of the inquiry. Indeed, the reference to the Royal Commission was quite precise: it was authorized to investigate "the conduct and administration" of the Manitoba Government Telephones by the Telephone Commission appointed January 15,1908 ; and in calling for evidence by means of public advertisements, the Royal Commission requested to hear from all associations and individuals " having complaints against the said administration." 12 Thus there was no pretense of any thorough inquiry: the subjects of investigation were to be the charges against the Telephone Commission, and, in its Report, the Royal Commission took credit to itself for having endeavored to induce such charges to be made. It is certainly clear that the Government, finding itself in danger from the indignation of the public, had resolved to sacrifice the Telephone Commissioners and had consequently put the Commissioners in the position of culprits at the bar - while the scales of justice were loaded against them. There is reason to believe

${ }^{12}$ Report of the Royal Commission (opening paragraphs). 
that the Winnipeg public suspected the intention of the Government and did not choose to lend assistance to a farce in which the Government pretended to assume a disinterested attitude but actually carefully concealed all important relevant matters. If this was the reason for the absence of the Winnipeg public from the sessions of the Royal Commission, their absence was very creditable to them: they refused to be parties to proceedings which could not fail eventually to bring discredit upon every one concerned.

Since the evidence taken by the Royal Commission continued until the end of April, before discussing this evidence chronology demands reference to two matters of record, indicative of the spirit in which the inquiry was conducted. Under date of March I, the Royal Commission made a brief interim report, consisting of a recommendation that the enforcement of the proposed rate schedule be postponed until the conclusion of the inquiry. ${ }^{13}$ There is no doubt that this recommendation was inspired by the Government, who thus utilized the inquiry as a means of unostentatiously disposing of the proposed rates - for the rates, thus indefinitely postponed, were quietly killed. A fortnight later, in the Legislative session of March I4, I9 I 2, the Opposition leader, evidently realizing that the Royal

13 Interim Report. Sessional Paper No. r9. Sessional Papers. Legislative Assembly of Manitoba. Session 1912, pp. 508-9.
Commission was largely under the thumb of the Government, moved that a committee of the Legislature be appointed "to examine and inquire into all matters relating to the Manitoba Telephone System." 14 The Government vigorously opposed this proposal and on a straight party vote it was defeated. ${ }^{15}$

TELEPHONE MISMANAGEMENT ASCRIBED BY THE ROYAL COMMISSION TO THE TELEPIIONE COMMISSION INSTEAD OF TO THE GOVERNMENT

From the proceedings of the Royal Commission it soon became evident that even the form in which the questions were put - when the evidence was being taken - showed the influence of the Government. Moreover, the interrogations by the members of the Royal Commission were lacking in precision; even those of the technical member of the Commission (Mr. Barry of Minneapolis) were characterized by vagueness. Members of the Telephone Commission were expected to answer from memory questions relating to accounts which were not placed before them, and conclusions were thus often based upon inaccurate or incomplete data. The Royal Commission also endeavored to cause the Telephone Commissioners to commit themselves to conclusions which had already been reached by the Royal Commission. Quite unfounded assump-

14 Journals of the Legislative Assembly of Manitoba, Session 19I2, p. 87. Cf. the Manitoba Free Press, Winnipeg, March 15, 1912.

15 Ibid., p. 88. 
tions which had been manufactured by members of the Government were introduced into interrogations and the Telephone Commissioners found themselves in a dilemma: they had either to initiate an attack upon the Government or to fence with the question. Nevertheless, in spite of all the difficulties with which they were continually beset, throughout the inquiry the Telephone Commissioners never made any reflections on the Government, thus displaying a standard of loyalty and honor quite consistent with their characters. A thorough realization of this attitude on the part of the Telephone Commissioners is essential to a proper perspective for considering the evidence before the Royal Commissioners, as over and over again the Telephone Commissioners were made to appear responsible for practices and conditions over which they had been deprived of control. ${ }^{16}$

In view of the partiality of the inquiry and the various assumptions, allegations and inaccuracies which appeared in the interrogations of the Royal Commissioners, it is not worth while to accord much space to the details of the evidence before the Royal Commission. In mere justice to the Telephone Commissioners, however, it is necessary to call attention again to the real causes for the existence of some of the conditions and practices for which the Commissioners, on the face of the evidence, seemed to be

${ }^{10} \mathrm{Cf}$. Stenographic Report passim.

\section{UNDER FIRST COMMISSION}

the responsible agents. For example, the Report of the Royal Commission comments upon the excessive quantity of supplies which the Telephone Commission kept in stock, pointing out for instance that on December 3I, I9II, there were 162,763 poles on hand, while nearly 20,000 more were contracted for but had not been delivered. "In fact," adds the Report, "poles were in hand at the beginning of this year sufficient at 40 poles per mile to build 4069 miles of pole line, which is within a very little of the total pole mileage constructed in the last four years." At that point, however, the Report stops abruptly, no mention being made of the reason for this excessive supply of poles. But the explanation, it will be remembered, has already been given: the Telephone Commission had practically been obliged by a member of. the Government to purchase an excessive number of poles from a client of his who was in financial difficulties. ${ }^{17}$ Again, the Report of the Royal Commission drew attention to the excessive amount invested in real estate, but entirely neglected to mention the fact that in connection with purchases of real estate, agents of the Government busied themselves to obtain commissions. ${ }^{18}$

In regard to the annual maintenance costs and the accounts of maintenance expenditure, the evidence before the Royal Commission was particularly dam-

17 Cf. p. 40, supra.

${ }^{18}$ Cf. the Manitoba Free Press, Winnipeg, March 6, 1908; The Tribune, Winnipeg, March 4, 1908. 
aging to the Telephone Commission; but even superficial analysis will relieve the Commission of responsibility for an undoubtedly pernicious state of affairs. In regard to the accounts, the Commission was deprived of financial control - as has already been fully explained ${ }^{19}$ - and thus reconstruction expenses were included with maintenance expenses. In regard to costs, as a result of the Government's policy of rapid expansion, the Commission found great difficulty in finding competent employees, partly because of the contemporary economic conditions in Manitoba and partly because of political conditions: the Commissioners scarcely dared to venture to appoint people from a distance even if they were procurable and, being confined to residents of Manitoba, they were forced to take Government nominees, partly through political pressure and partly because men were scarce. ${ }^{20}$ Large numbers of the men who had to be employed were unfamiliar with the work which they were required to do. Even "plant chiefs" were unequal to the tasks assigned to them; and thus the discipline of the working gangs was very defective. Incompetent foremen were promoted to responsible positions because there was no alternative or appeared to be none. The Construc-

\footnotetext{
19 Cf. p. $4 \mathrm{I}$, supra, et passim. Another explanation perhaps is that the Government did not require, and perhaps did not desire, scrupulous accuracy in accounting. It was easier to hide deficiencies when the accounts were kept in a loose manner.

${ }^{20}$ Cf. pp. 40, 44 and 77, supra, and p. I06, infra.
}

tion Engineer was helpless; he not only had to work with the material at his disposal, but he had to force the work. During I910, 25 to 35 crews were working and it was impossible to provide a skilled foreman for each crew. Under such conditions it was inevitable that a certain amount of fraudulent practice should arise. ${ }^{21}$ In I9I I the construction was pushed into very difficult country, topographically, while the season was very rainy - all of which involved unusually high expenses. ${ }^{22}$

While the technical and the labor conditions rendered both maintenance and construction costly, these were not the only conditions which made for excessive expenditure - there was always the pervasive political influence. For example, the following statement, though colored with political partisanship, is so consistent with known facts that some weight must be attached to it. The statement was contributed to the Manitoba Free Press by a correspondent at Brandon: "A high official of the government telephone system here, let the cat out of the bag this morning. Speaking to a staff man of the Free Press who is a stranger to him he stated in the most emphatic terms that every branch of the

${ }^{21}$ In a number of instances, construction foremen secured vouchers for larger sums than they had actually expended - and pocketed the difference. There was also a certain amount of leakage in connection with supplies.

${ }^{22}$ Cf. Fourth Annual Report of the Commissioners of Manitoba Government Telephones, IQIT. Sessional Paper No. 25. Sessional Papers. Legislative Assembly of Manitoba. Session IgI2, p. 533. 
telephone system in the province was being used for political purposes. 'Some of my men,' he said, ' have been working practically night and day during the past three weeks and a great sigh of relief will go up from every telephone man when the elections are over. ${ }^{23}$ In the Brandon district several extra gangs were put on a short time ago to get the goodwill of the people and at the present time in this one district we have no less than 42 gangs working, each one of which is composed of 25 to 35 men. In addition to that canvassers have been sent out, not only through this district, but every part of Manitoba, to have the farmers sign applications in the belief that a telephone line is about to be installed by a generous government. The whole thing is one huge political graft and we who are rushed to death are heartily sick of it." " 24

Another contemporary criticism from the Free Press may be held to state the case accurately: "The deterioration of the telephone service is a standing proof of the manner in which the combination of public ownership and machine politics results to the injury of the farmer. The complaints of the unsatisfactoriness of the telephone service are constant. That unsatisfactoriness has gone on increasing since the beginning of the present system in the Province of having the telephone system ad-

23 The elections referred to were those of July Ir, x9Io.

24 The Manitoba Free Press, Winnipeg, July 9, rgro. ministered by a Commission which is hampered and obstructed by politics. The Commissioners are not politicians. But they have to do what the politicians in power want done. The result is that the system is loaded with employees appointed for political reasons. ... If the Commissioners were independent of the control of the politicians, they would manage the telephone system on purely business lines. As it is, they have to administer it on political lines." 25

Strictly non-partisan newspapers were scarcely less severe. For example: "There is no mincing of matters by the man-in-the-street, whether Grit or Tory; it is felt that the undoubted managerial ability of the Chairman of the Telephone Commission ... and of other able officials, is too largely offset by indirect, if not direct, influences not unconnected with politics." 26

The Royal Commissioners made no mention of accrued depreciation or of a sinking fund for the amortisation of the debt. The only reference to a related question is in the following brief sentences: "Up to I9I 2 there has not been any replacement account, such expenditure being included in maintenance. We are of opinion that such account should

\footnotetext{
${ }_{25}$ The Manitoba Free Press, Winnipeg, June 21, 1910.

${ }^{2}$ Canadian Finance, Winnipeg, December $20,191 \mathrm{r}$. It is need. less to state that members of the Government of course always denied such charges and insisted that the Commission was not subject to
political influences.
} 
be instituted." ${ }^{27}$ The implication is that the Telephone Commission was responsible for the fact that no reserves of any kind were set apart. The statement is thoroughly disingenuous. The question of depreciation alone was vital to the whole inquiry. The sole power to provide reserves lay not with the Telephone Commission, but with the Government; ${ }^{28}$ yet the Royal Commissioners chose to ignore this important fact; and a ridiculous climax was reached when, in their Report, the Royal Commissioners completely whitewashed the Government.

By instruction of the Royal Commission, Messrs. Webb, Read, Hegan, Callighan and Co., Chartered Accountants, made an examination into the system of bookkeeping used by the Telephone Commission during the years 1909 to I $9 \mathrm{II}$; but this examination was not permitted to include an audit of the books. ${ }^{29}$ In their Report, the accountants indicated that from the beginning of Government operation the system of bookkeeping employed was scarcely commensurate with the magnitude of the undertaking. ${ }^{30}$ It must be realized that prior to the acquisition of the telephone system by the Government, the records of transactions were all forwarded to the head office at Montreal where the books of the Bell Company were kept. When the Government took over the system,

27 Report of the Royal Commission.

26 Cf. pp. $4 \mathrm{I}-42$ and $7 \mathrm{I}$, supra.

29 Accountants' Report (typewritten), May 1 5, 1912.

${ }^{30}$ Ibid. it was clearly their duty to transfer the functions previously exercised by the head office either to the Telephone Commissioners or to the Telephone Department. As a matter of fact, however, the Government adopted neither course. They entertained the fantastic idea that head office functions were unnecessary; indeed, one of their arguments in favor of the acquisition of the system was that the head office expenses would thereby be eliminated altogether. ${ }^{31}$ Moreover, when the Telephone Commission was appointed, the control over construction was expressly reserved to the Telephone Department, i.e., to the Government. ${ }^{32}$ Yet the construction had to be carried out by the officers of the Commission, and the supplies in the hands of the Commission had to be drawn upon for construction purposes. The result was inevitable confusion between the construction and the operating accounts, and great confusion in the stores accounts. Some of the defects in accounting were gradually remedied; but even apart from the confusion entailed by the division of responsibility, it would appear that the internal organization of the system was not able to expand to keep pace with the excessive speed in construction demanded by the Government. ${ }^{33}$

As has been indicated, throughout the long course of the Telephone Investigation from the beginning

\footnotetext{
${ }^{31}$ Cf. p. 33 , supra. $\quad{ }^{33}$ Cf. pp. 43-44, supra.
} 
of February until the end of April, igr 2, the Telephone Commissioners conducted themselves with dignity and, for the most part, in silence. The Royal Commissioners explicitly state in their Report that they received from the Telephone Commissioners, upon requisition, "a tremendous amount of statistical and other information"; and they express their obligations to the Telephone Commission,especially to the Chairman for " the courteous and kindly manner in which he responded to our constant demands upon him." The Royal Commissioners, however, felt that they should " report that all evidence got was the result of and in answer to our own efforts and requisitions, and the (Telephone) Commissioners apparently did not consider it their duty, and as a matter of fact did not offer or volunteer any evidence whatever in aid of the inquiry or otherwise." 34

This naturally was the dignified course for the Telephone Commissioners to pursue. The Chairman of the Telephone Commission must have realized the fraudulent character of the Royal Commission. He could not impede it, but he could at least refrain from giving its ridiculous proceedings the advantage of his spontaneous assistance. The injustice and cowardice of the Government are beyond description. The members of the Government knew perfectly well what they were doing: they were

34 Report of the Royal Commission. deliberately making scape-goats of men whom they had induced to enter their service on the pretense that they intended to conduct the telephone business on sound commercial lines. When the Telephone Commissioners pointed out that the policies of the Government were inconsistent with sound business principles, they were told that their advice was not wanted; but when these policies aroused the indignation of the public, the members of the Government attempted to divert that indignation upon the heads of the Commission by instituting a tribunal for the purpose of trying the Commissioners as if they were culprits, - an ingenious but discreditable device.

In general the Report of the Royal Commissioners is an inconclusive and unsatisfactory document, for the conduct of the Telephone Commissioners was inquired into and not the conduct of the Government. At every point the inquiry led to the threshold of the Government - but there it stopped. Instead of honestly taking their share of the blame, the Government chose the dishonorable course of virtually prosecuting the Commissioners, whose faults arose solely from the fact that they were consistently loyal to a Government which was disloyal to them. The people of Winnipeg, irrespective of political party, seemed to have understood the situation and spontaneously declined to be parties to the infamous proceedings. 


\section{RESIGNATION OF THE TELEPHONE COMMISSION}

When the Report of the Royal Commission was presented toward the end of May, igi 2, the Government - in spite of the fact that nothing whatever to the discredit of the members of the Telephone Commission had emerged during the sessions of the Royal Commission - appear to have reached the conclusion that the easiest method of extricating themselves from the difficulties in which they were involved, would be to have the two remaining Commissioners sever their connections with the telephone system. $^{35}$ Now, if the Commissioners were dismissed from office they would be in a position to embarrass the Government by disclosing the true state of affairs; but if they could be induced to resign, the faults of the Government would be carried with them into oblivion. An emissary of the Government succeeded in securing the resignations of the Commissioners to take effect on July I, I9I2, although they did not actually leave office until two weeks after that date. That the resignations were in a manner forced, there can be no doubt; yet the withdrawal of the Commissioners "saved the face" of the Government and afforded the members of the Government an opportunity of rehabilitating their declining political fortunes.

35 The Commissioner Auditor had resigned on February 17, r912. Cf. the Manitoba Free Press, Winnipeg, February 17, 1912.
The following is a copy of the letter of resignation addressed to the Premier, dated June 27, 19 I 2, and signed by both Commissioners:

"Pursuant to your request just conveyed through the Hon. Mr. Coldwell, we hereby tender our resignation as Commissioners of Manitoba Government

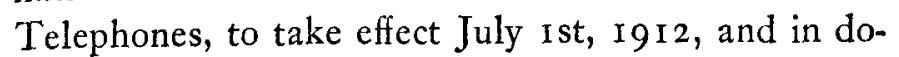
ing so may we express the hope and belief that neither your Government nor our successors will be misled by the gross misstatements of fact, and the erroneous opinions and conclusions expressed in the Royal Commission's report."

With the resignation of the Telephone Commissioners, the first phase of the history of the Manitoba Government telephone system comes to a close. The entire period was dominated by political influence and political considerations, more or less effectually concealed behind the elaborate pretenses and the fair words of the Government. The pledge of non-partisan commercial management was not kept. The Bell rates, far from being "cut in two" as promised on so many occasions, were maintained intact for fifteen months, when the Government effected such slight reductions as might best redound to their political advantage. These unwarranted reductions, when combined with the political accounting methods employed by the Government, con- 


\section{4 GOVERNMENT TELEPHONES}

tributed largely to the disastrous failure to fulfill the promise that the service would be self-sustaining. Finally, finding themselves in jeopardy from the wrath aroused by the force of the contrast between promise and performance, the Government deliberately sacrificed their loyal servants that their own sins might go unpunished. After four years of public ownership a prosperous business was well along the road to ruin.

\section{III \\ THE GOVERNMENT SYSTEM REORGANIZED}

APPOINTMENT OF A SINGLE TELEPHONE COMMISSIONER FOLLOWED BY OSTENSIBLE, BUT LARGELY

INEFFECTUAL, ADMINISTRATIVE REFORMS

UPON the sudden, though not undesired, resignation of the Telephone Commission originally appointed, it was incumbent upon the Government immediately to give some outward and visible sign of an intention to purge the Provincial telephone system of the more conspicuous of the evils which accompanied political control; for a reform of the system - or at least the semblance of a reform was essential to the Government's political welfare. Accordingly, on July I, I9I2, Mr. R. L. Barrywho had been a member of the Royal Commission - was appointed to act as sole Telephone Commissioner, and was charged with the duty of reorganizing "the property and management" 1 so

1 Fifth Annual Report of the Manitoba Government Telephones for the fiscal year ending November 3oth, 19I2, p. 3. (This is the first annual report of the Government telephone system which was 
as to produce the quick results demanded by the political situation, or, in other words, so as to enable the Government to make immediate political capital out of an alleged telephone " reform." 2 Although it appears from the contemporary Opposition press that Mr. Barry did not actually assume charge of the system until July I 6 th, ${ }^{3}$ yet so well did he fulfill the requirements of speed that on August I6th, exactly one month later, the work of reorganization was completed and he was able to resign. ${ }^{4}$ There is considerable doubt, however, as to what took place under the reorganization; the details given in the annual report of the system for the fiscal year I9I2 were couched in such ambiguous political phraseology and were so palpably contradictory as to be practically meaningless. Nevertheless, even from superficial analysis of the official reports it is clear that the political principle of "reform for reform's sake" was carried out in many ways, that changes in form took place rather than changes in substance; and, although it is probable that some beneficial changes were effected-especially in the methods of purchasing and of handling supplies - the conclusion is

issued as a separate document in addition to being printed among the Sessional Papers.)

$2 \mathrm{By}$ the appointment of the investigator as the administrator, the Government adopted a not unusual political method of assuaging popular discontent and distrust.

3 Cf. the Manitoba Free Press, Winnipeg, July 4, rgr2.

${ }^{4}$ Fifth Annual Report of the Manitoba Government Telephones for the fiscal year ending November $30 t h, 19 I 2$, p. 3. inevitable that the reorganization was largely nominal. The cost of the "reorganization" (\$14,600 ), though, was by no means nominal.

The result of the "reorganization" is stated to have been the immediate diminution of unit operating costs. ${ }^{6}$ As a matter of fact, however, the existence of a relationship of cause and effect between the "reorganization" and the reduction of costs is not established. That expenses were somewhat reduced is clear; but the reduction was to a large extent a purely political move on the part of the Government, who produced it by temporarily sacrificing some of the influence which it and its political adherents had been accustomed to exert. Furthermore, the "reorganization" developed a good deal of friction among the employees, with the result that a large number of employees holding executive positions resigned; and the Government took advantage of the opportunity and effected appreciable economies by reducing the salaries attached to these superior positions, - a practice which is by no means infrequent in Government departments.

Upon the resignation of Mr. Barry (August 16 , I9I2), Mr. George A. Watson of Minneapolis was appointed Commissioner of Telephones and the system was placed under the supervision of an Advisory

${ }^{5}$ Fifth Annual Report of the Manitoba Government Telephones for the fiscal year ending November 30th, 1912, p. 12 .

${ }^{\circ}$ Ibid., p. 4 . 


\section{I 8}

GOVERNMENT TELEPHONES

Board of which Mr. H. A. Robson, K. C., the Public Utilities Commissioner (a Public Utilities Commission having been created in April 19 I 2$)^{7}$ was a member. The effect of this change was to give the Commissioner of Telephones considerably more independent executive power than the original Telephone Commission had ever been allowed to exercise, while the conspicuous supervisory powers (for example, in regard to rates and depreciation charges) were transferred from the Minister of Telephones and Telegraphs to the Public Utilities Commissioner. ${ }^{8}$ However, the Government continued to retain the inconspicuous supervisory power, that is, the power to exert influence in subtle and obscure ways to make use of the telephone system for political purposes; indeed, unless some concrete political advantage could be derived from the system, the Government would have regarded the enterprise as a total loss politically - as a political liability rather than as a political asset. Nevertheless, in consequence of this change, an appreciable improvement may be assumed to have taken place in the relations between the telephone system and the Government; it is certain that the feverish energy of ineconomical expansion for political ends was checked. But it must be emphasized

${ }^{7}$ Journals of the Legislative Assembly of Manitoba, Session Igza, p. 175 .

8 Cf. An Act respecting Public Utilities, to create a Public Utility Commission and to prescribe its Powers and Duties. The Revised Statutes of Manitoba, 1913, vol. iii, Chap. 166. that this improvement did not represent any deliberate attempt on the part of the Government toward a belated fulfillment of their promise of commercial management; on the contrary, it was solely a concession to public opinion, a concession forced by the Government's fear of the political consequences of further reckless expenditure and brazen mismanagement and granted only to a degree which was calculated to appease public opinion. Moreover, it is highly significant that the improved conditions were largely due to the ability and integrity of the Public Utilities Commissioner, whose personal character and career inspired the public with confidence. In other words, here is really excellent evidence of the fact that, in the conduct of public utilities, an impartial and efficient regulatory tribunal - or even individual - secures results which it is impossible to attain under any system of unregulated political control.

EXCHANGE RATES INCREASED; PRIVATE TELEPHONE COMPETITION PREVENTED

By their tactics - by the appointment of the investigating Commission, by the resignation of the original Telephone Commission and by the widely advertised "reorganization" of the system - the Government succeeded in their purpose of allaying public indignation. ${ }^{9}$ Consequently, during the suc-

${ }^{9}$ This result was also partly due to the fact that the wrath of the 
ceeding years there is relatively little documentary evidence as to the inside workings of the system; indeed, practically the sole black and white information consists of the brief annual reports of the Telephone Commissioner. Moreover, these reports offer little assistance to the analytical investigator, for they are essentially political documents; and the Government met attempts to go behind the published returns with reluctance and with evasion, - the best possible evidence that all the workings of the system were not able to stand the light of day.

It will be recalled that the proposed rate schedule which had been prepared by the Telephone Commission in December I9I I, and which was based largely on measured service, had been quietly killed by the Government. ${ }^{10}$ The need for increased revenue, however, survived; every day which passed under the existing rates meant a further step toward actual bankruptcy. While the investigation was in progress the Government lacked the audacity to submit another rate increase to the public; but the investigation having been completed and a "reorganization" of the system having been announced, the time was politically ripe for effecting a general increase of rates. The suitability of the occasion was not lost upon the politicians in the Government and on July

public had been diverted from telephones and had been directed against the Government's maladministration of the publicly-owned grain elevators.

${ }_{10}$ Cf. p. 1oo, supra.
25, 19I2, the Telephone Commissioner, having secured the necessary approval of the Public Utilities Commissioner, issued a new schedule of rates applicable to Winnipeg. On August I $3^{\text {th }}$ a new schedule of rates applicable to the rest of the Province was issued. ${ }^{11}$

These new schedules provided flat (unlimited service) rates only - apparently the politicians wanted nothing further to do with measured rates, however equitable such rates might be. In Winnipeg, the rate for individual line, business service (the only class of business service which the new Winnipeg schedule offered) was raised from $\$ 5^{\circ}$ to $\$ 60$ per year, an increase of 20 per cent.; the rate for individual line, residence service was raised from $\$ 25$ to $\$ 30$ per year, an increase of 20 per cent.; and the rate for two-party line, residence service was raised from $\$ 18$ to $\$ 25$ per year, an increase of 39 per cent. In the smaller towns and in the rural districts, the increases ranged up to 67 per cent. Even the Government press admitted that the new rates involved "considerable" increases! ${ }^{12}$

The new schedules showed an arbitrary treatment of the consumer which was truly Governmental. In the first place, the recommendations both of the Win-

11 First Report of the Public Utilities Commissioner Manitoba for the Six Months ending November 3oth, IgI2. Sessional Paper No. Ir. Sessional Papers. Legislative Assembly of Manitoba. Session I913, pp. 546-556.

${ }^{12}$ The Winnipeg Telegram, July 19, x912. 
nipeg Industrial Bureau and of the Board of Trade ${ }^{13}$ were silently ignored. In the second place, the schedules, approved and promulgated on July $25^{\text {th }}$ and on August I 3 th, were retroactive, becoming effective as from July Ist. About the Ioth of July telephone subscribers received the following circular:

"A bill has recently been sent you for telephone rentals. No rates have as yet been approved by the public utilities commissioner. A new bill will be sent you in a few days." 14

During the first half of July, in spite of the fact that bills had been rendered, subscribers were in absolute ignorance as to how much their telephone service was costing them.

Contemporary press reports throw another interesting and significant side-light on the new rates. It appears that, immediately after these rates were announced to the public, a private power company applied to the City Council of Winnipeg for permission to install and to operate a telephone system in that city, the representative of the company declaring that "the matter of rates had been fully considered" and that "the company had decided that it could give private residence service at $\$ 20$ per year and a general business service at $\$ 40$ per year." 15 In other words, the company offered to cut the Government rates by one-third. Nevertheless, when the

\footnotetext{
13 Cf. pp. 93-94, supra.
}

14 The Manitoba Free Press, Winnipeg, July r3, r9r2.

15 Cf. the Manitoba Free Press, Winnipeg, July 23, I912. company's application was referred to the Works Committee, that body, although conceding the merits of the proposal, denied the application on the ground that " it would be poor business for the citizens of Manitoba to allow a new company to come in to compete with the government telephones." ${ }^{16}$ As the citizens of Manitoba are the proprictors of the Provincial telephone system, it certainly would have been "poor business" for them to have had to enter into competition with any system which showed prospects of being efficiently and economically constructed and operated!

A recommendation contained in the Telephone Commissioner's report on the "reorganization" of the system, submitted in August 19 1 2, also deserves attention. According to the newspapers, "it was recommended in the commissioner's report that the construction work be let out on contract." ${ }^{17}$ Being interpreted, this recommendation is an open admission that the Government could secure economy by turning their construction work over to private enterprise. $^{18}$

\footnotetext{
${ }^{16}$ The Winnipeg Telegram, October 5, I912.

17 The Manitoba Free Press, Winnipeg, August 24, 1912.

$18 \mathrm{It}$ is interesting to note that the annual report of the Postmaster General of the United States for the fiscal year ended June 30, I9I4, contains a similar recommendation. In this report Mr. Burleson stated: "There can be no question as to the one outstanding, selfevident fact that the identical service to rural mail patrons can be maintained at this time with a saving of from $\$ 1_{5}, 000,000$ to $\$ 20$, 000,ooo per annum, and it is earnestly recommended that the necessary legislation for placing all Rural Delivery Service on a contract basis
} 


\section{TELEPHONE ACCOUNTS STILL DEFECTIVE; A REAL}

LOSS OF OVER \$2OO,OOO IN I9I2

In I9I 2 the fiscal year for Provincial Government departments was changed to close, in that year and thereafter, on November 3 oth, instead of December 3 Ist. The published telephone accounts for I 9 I $2{ }^{19}$ therefore covered only eleven months, a period which included six months under the original Commission and five months under the "reorganized" administration. The accounts were checked and summarized by the firm of chartered accountants who had been appointed as auditors and, as might be expected, were much more complete and intelligible than those in former years. For instance, it was immediately noticeable that current expenses for the first time included a depreciation charge; for the Government had realized that they could no longer with impunity violate sound accounting principles as to depreciation and had acceded to the insistent demands of the Public Utilities Commissioner and of the auditors that a reserve to meet reconstruction expenses be set aside from each year's revenue beginning with I9I2. Consequently, the accounts for the first time also

be enacted in order that the people may receive the maximum return for the minimum expenditure of their money." Needless to say, Congress refused to enact the "necessary legislation" which would thus enable the United States Post Qffice Department to save from $\$ 1_{5,000,000}$ to $\$ 20,000,000$ per year - on a single branch of the postal service - by utilizing the efficiency of private labor.

19 Fifth Annual Report of the Manitoba Government Telephones for the fiscal year ending November 3oth, 1912, pp. 6-14. showed maintenance expenses as a separate item, all reconstruction expenses during the fiscal year having been properly met from the depreciation reserve which had been set aside during the year. ${ }^{20}$

In spite of this improvement in accounting methods, however, it is still impossible to discover the real financial outcome of the year's business from the published accounts. The accounts showed a "balance" of revenue of $\$ 366,148$; but interest charges upon telephone capital were again omitted. Moreover, although the accounts conformed to sound accounting principles in that a depreciation charge was included in current expenses, yet the amount of the charge ( $\$ 126,000)$ failed to conform to the requirements of the best engineering experience and was quite inadequate to provide a sufficient reserve against accrued depreciation,- a fact which was pointed out by the auditors ${ }^{21}$ and admitted by the Telephone Commissioner. ${ }^{22}$ Consequently, it is necessary to recast the accounts by increasing the depreciation charge to a sum sufficient to provide an adequate reserve; with such a depreciation charge and with the inclusion of interest charges, the accounts for the eleven months are as follows:

\footnotetext{
${ }^{2}$ Incidentally, it will be noted that the method of dealing with reconstruction expenses in the accounts which has now been adopted by the Government is precisely the method which has been used here in recasting the telephone accounts in the preceding years. Cf. pp. 54-57, supra.

21 Fifth Annual Report of the Manitoba Government Telephones for the fiscal year ending November 3oth, 1912, p. 13.

22 lbid., p. 6.
} 
Gross Revenue ........

$\$ 1,352,876$

Expenses:

Operation $\ldots \ldots \ldots \ldots \$ 584,823$

Maintenance ....... 275,905

Depreciation ....... 405,891*
Total Expenses ....

I,266,619

86,257

Net Earnings ..........

Interest $\ldots \ldots \ldots \ldots \ldots$

$314,705^{23}$

Deficit $\ldots \ldots \ldots \ldots$. .
* Equivalent to $6 \%$ of plant cost at the end of the preceding year; adjusted to cover eleven months only.

It is clear, then, that the system was actually worked at a greater loss during the fiscal year I9I 2 than during the calendar year of I9II. But even this result is too favorable, for it will be noted that the interest charges in 1912 were considerably less than those in the preceding year: owing to the change in the date of the closing of the fiscal year, the Public Accounts included only six months' interest upon a considerable amount of the Provincial bonded indebtedness incurred for telephone purposes. ${ }^{24}$ If the interest charges had represented the whole amount of interest accrued upon all telephone capital during the eleven months included in the fiscal year, the above deficit would have been increased by a sum of about $\$ 50,000$. Thus the accounts offered the mulcted taxpayer little hope of relief; but since

\footnotetext{
${ }^{23}$ Sessional Papers. Legislative Assembly of Manitoba. Session 1913, p. 62.

$\because$ Ibid.
}

the increased rates had been in force only during less than one-half (five months) of the fiscal period, the full effect of the increase could not be expected until the next year, the first complete year under the new administration.

\section{INADEQUATE PROVISION AGAINST DEPRECIATION; REAL FINANCIAL RESULT IN I9I 3 AGAIN \\ A DEFICIT}

The telephone accounts for the next year, ${ }^{25}$ the twelve months ended November 30, 1913, were the most comprehensive accounts published up till that time, and they reflected the beneficial influence of the Public Utilities Commissioner. Interest charges were included for the first time and the depreciation charge was increased to $\$ 373,43 \mathrm{I}$ - with the result that the accounts, instead of showing a huge credit "balance" as in former years, showed a "surplus" of only $\$ 30,265$, of which $\$ 26,69$ I was set aside as an additional reserve against depreciation, leaving a credit balance of only $\$ 3,574$. The depreciation charge was equivalent to the estimated loss in value due to the depreciation during the year of the plant at the end of the preceding year, the estimate of this loss in value being based upon a calculation of the "average life, plus cost of removal, less salvage" of each of the principal kinds of tele-

${ }^{25}$ Sixth Annual Report of Manitoba Government Telephones for the fiscal year ending November 3oth, 1913, pp. 8-15. 
phone plant. ${ }^{26}$ This calculation of the average life of the various kinds of plant, however, was palpably erroneous and unscientific; for instance, all buildings were entirely omitted from the calculation - although buildings are subject to deterioration like other kinds of plant - and the average life of rural pole lines was placed at twenty years despite the abnormal deterioration to which such lines are subject in view of the "extraordinary weather conditions " ${ }^{27}$ in Manitoba. The result was that the depreciation charge was equivalent to only $4.2 \%$ of the book value of the total plant, ${ }^{28}$ or to only $4.8 \%$; of the actual plant cost, i. e. excluding the cost of intangibles and the maintenance expenses improperly charged to capital. ${ }^{29}$ It is clear, therefore, that this charge was again inadequate. ${ }^{30}$ When an adequate

${ }^{26}$ Report of the Public Utilities Commission for the fiscal year ending 3oth November, 1913. Sessional Paper No. 24. Sessional Papers. Legislative Assembly of Manitoba. Session 1014, p. $\mathbf{3 2 2}$.

27 Seventh Annual Report of the Manitoba Government Telephones for the fiscal year ending November $301 h$, 1914, p. 14.

28 The charge was equivalent to $4.91 \%$ of the book value of such plant as was taken into consideration in determining the charge.

${ }^{29}$ It will be recalled that the cost of intangibles and the amount of the maintenance expenses charged to capital was determined by a subsequent appraisal of the plant made in 1915. Cf. p. 54, supra.

30 Although the Public Utilities Commissioner approved the amount of the depreciation charge, yet he was not in a position to express an opinion as to its adequacy. Even assuming that he had an independent staff of telephone engineers to advise him, which he had not, there could be no indication of the adequacy of any depreciation charge so long as such a charge was based, not upon the plant cost, but upon the book value of the plant, since the book value of the plant included the cost of intangibles and the maintenance expenses improperly charged to capital during the first reserve against depreciation is provided, the accounts reveal the following result:

$$
\begin{aligned}
& \text { Gross Revenue } \ldots \ldots \ldots \text {. } \\
& \$ 1,707,150 \\
& \text { Expenses: } \\
& \text { Operation ........\$ \$598,637 } \\
& \text { Maintenance ........ } 297,842 \\
& \text { Depreciation ....... 465,538* } \\
& \text { Total Expenses .... 1,362,017 } \\
& \text { Net Earnings ........ 345, I33 } \\
& \text { Interest } \ldots \ldots \ldots \ldots \ldots . \\
& \text { Deficit } \ldots \ldots \ldots \ldots \ldots \ldots \ldots
\end{aligned}
$$

* Equivalent to $6 \%$ of plant cost at the end of the preceding year.

Although the real financial result of the fiscal year I9r 3 was thus a loss of at least $\$ 60,000$, nevertheless this result was a great improvement over the results in I $9 \mathrm{Ir}$ and $\mathrm{rgr} 2$. It is certain, however, that this improvement was due almost solely to the increase in exchange rates; it will be recalled that the new rate schedule involved increases of 20 per cent. and upwards and thus probably brought an increase in gross revenue of approximately $\$ 200,000$ per year. Indeed, the gross revenue from exchange service during the year averaged $\$ 3 \mathrm{I} .75$ per telephone, or more than the corresponding average revenue received in 19I3 by the entire Bell Telephone System in the United States, with its many huge exchanges! ${ }^{31}$

three years of Government operation. It is also significant that practically all of the year's "surplus" was set aside as an additional reserve against depreciation.

${ }^{31}$ Annual Report of the Directors of American Telephone and 
While it is true that a number of operating and administrative economies were effected during the year, some of these economies were in reality more detrimental than beneficial to the service. This was especially true in regard to the economies in salaries and wages resulting from the Government's policy of employing cheap labor. ${ }^{32}$ Although the adoption of this policy was possibly due to the fact that such economies were the most obvious and the least dangerous politically, nevertheless it cannot be denied that it has always been difficult to convince the rural voter that any man is worth a salary of more than $\$ 2,000$ a year. Consequently, although the Public Utilities Commissioner found the system in need of technical assistance of a high order, he was forced to take the position that the expenses of the employment of experts should be saved. ${ }^{33}$ It is true, as indicated in the Annual Report, ${ }^{34}$ that some increases in employes' wages, especially as regards the schedule of operators' wages, were granted in I9 3 ; but these increases were largely the result of pressure by labor

Telegraph Company to the Stockholders for the year ending December 37,1913, p. 13 .

32 For example, as has already been pointed out, the Government endeavored to economize by reducing the salaries attached to superior positions. Cf. p. x17, supra.

${ }^{33}$ First Report of the Public Utilities Commissioner Manitoba for the Six Months ending November 3oth, Ig12. Sessional Paper No. 11. Sessional Papers. Legislative Assembly of Manitoba. Session $190 \mathrm{r}$, p. $48 \mathrm{r}$.

${ }^{34}$ Sixth Annual Report of the Manitoba Government Telephones for the fiscal year ending November 30th, 1913, p. 2. organizations and by no means eliminated wage dissatisfaction.

\section{QUALITY OF SERVICE UNSATISFACTORY}

The Annual Report for I9I 3 contained one feature which will probably be continued in future reports, namely, an attempt to prove by statistics that - no matter what the experience of the subscribers may have been - the service is increasingly satisfactory. For instance, the Report for I9I 3 stated:

"Throughout the Province, exclusive of Winnipeg, 4,4 I3 subscribers were personally interviewed or called up during the year, with results as follows:

83. per cent. reported service satisfactory;

Io. 6 per cent. reported service fair;

6.4 per cent. reported service unsatisfactory." ${ }^{35}$

On its face this statement has a wholesome ring, even though it admits that in spite of the " reorganization " of the system the Government had succeeded in satisfying only 83 out of every 100 customers, certainly not an enviable commercial record! As a matter of fact, however, the statement is a mere political device for disarming obnoxious criticism. Other Governments have availed themselves of the ingenuousness of statements of this character for similar purposes.

After the British Post Office at the end of 19II

${ }^{35}$ Sixth Annual Report of the Manitoba Government Telephones for the fiscal year ending November 30th, 1913, p. 2. 
had acquired a monopoly of the telephone business in the United Kingdom by purchasing the plant of the National Telephone Company, the public continually complained that the service as operated by the Government was inferior to that formerly furnished by the Company. In replying to some of these complaints, in the House of Commons on July 3, IgI4, the Postmaster General stated that the Post Office had sent out inquiries to I35,000 out of 209 ,ooo subscribers in London, with the result that 87 per cent. stated that they were perfectly satisfied with the service they were receiving from the Government. $^{36}$ Upon investigation by still skeptical critics and customers, however, it was revealed that the "inquiry" of the Post Office had consisted merely of asking the subscriber if his line were working all right, whereupon those subscribers whose lines were not at that particular moment out of order naturally responded in the affirmative, and were recorded as finding the service satisfactory. ${ }^{37}$

It is clear that any inquiry of this nature offers countless opportunities for manipulation, to the end that the results secured may be favorable to the contentions of the persons conducting the inquiry; and unless the good faith and the impartiality of the inquiry is assured, the results are meaningless. In the case of the Manitoba Government system, the

${ }^{30}$ Parliamentary Debates. House of Commons. Friday, 3rd July, 1914. Official Report. Column 773.

${ }^{37}$ The Morning Post, London, July 13, 1914. above statistical statement of satisfactory service must be read in the light of a record of some of the "irregularities" experienced by the Public Utilities Commissioner with the telephone (Main 3024) in his own office. This record was so significant that it was published in the Report of the Public Utilities Commission for the fiscal year I9I3 under the heading of "Partial Record of Telephone." The Commissioner's illuminating experience follows :

"August 21, I913.- Main 3034 asked for three times; telephone rang and I was asked what number I wanted; went to telephone on call three times, party had been asking for number of National Transcontinental, and was told it was M. 3024 .

"August 22, I913.- Main 301 4 asked for.

"August 26, I9 I3.- Main 3034 wanted; called Main 3024.

"September I, I9I3.- 'Phone rang; no one on the line.

"September 2, I9 13.- McMillan's (M. 3034) 'phone again; ditto twice.

"September 4, I9I3.- Call for M. 3025.

"September Io, I9 I3.- Twice called for wrong 'phone; once M. 2034, once M. 3034.

"September I I, I9 I3.- Called for Main 3034.

"September 29, 19I3.- 'Phone rang, no one there.

"September 30, r9 $3 .-$ Cut off in the middle of conversation with $\mathrm{Mr}$. 


\section{34}

GOVERNMENT TELEPHONES

"October I, I9 13.- Called for wrong number, M. 3034; ditto; asked for M. 809 I ; asked for McMillan's number, M. 3034; wrong number, some person wanted M. 4034; wrong number given again.

"October 6, I9I3.- Called for Mr. Wright; called for Standard Trust.

"October 8, I9I3.- 'Is Mr. Elliott there?"

"October 9, I9I3.- 'Is that Clark's?" 'Is that McMillan's?' M. 3034 called.

"October 16, I913.- - Twice rang for nothing. 'Is that M. 3034 ?' 'Is that Clark \& Co.?'

"October 2I, I9I3.- M. 3034 wanted.

"October 23, I913.- M. 3034 wanted.

"October 24, I9 13.- Called for M. 3824 ; called for M. 3034 .

"October 27, I913.- Called for M. 3025; called for M. 3034 .

"October 28, I913.- Called for Clark's; ditto.

"October 29, I9 3.- Called for wrong 'phone.

"November I0, I9 I3.-Bell rang twice; girls say 'Number?'

"November I I, I913.- Called for M. 3034 .

"November I4, I913.- 'Is that Clark's?'

"November I8, I913.- Called for M. 3034.

"November 19, 1913.- Asked for M. 3034.

"November 22, I9I3.-Called for M. 3034; called for M. 3025 ; called for McMillan's.

"November 24, I913.- Called for Mr. Miller. 8024 )

"November 25, I9 I3.- 'Is that Clark's?' (M.

"November 28, I9 13.- Called for M. 3034.

"November 29, I913.- Called for M. 3034.

"December 8, I9I3.- Twice called for McMillan's (M. 3024); once for J. D. Clark's (M. 8024).

"December 13, r913.- Called for McMillan's; I asked for Sher. I489, got the Winnipeg Brewery; called for M. 3034 .

"December I5, 1913.- Asked for Sher. 1489 and got wrong number; then when got the right number cut off in conversation.

"December 22, I9I3.- Twice called for $M$. $3 \circ 34$.

"December 23, I9I3.- Called for M. 3034.

"December 27, I9I3.- Called for M. 3034 .

"December 30, I9I3.- Called for M. 3025.

"December 3I, I9I3.- Called for M. 3034 .

"January 2, I9 I 4.- Called for M. 3034; called for M. 3034 .

"January 7, I914.- Bell rang, no call.

"January IO, I9 I 4.- Called for M. 3034.

"January I 2, I9 I 4.- Called for M. 30 I4.

"January 12, I9 I 4.- Called for M. 3034.

" January I 4, I 9 I 4.- Called for M. 3025." 38

38 Report of the Public Utilities Commission for the fiscal year ending 3oth November, 1913. Sessional Paper No. 24. Sessional Papers. Legislative Assembly of Manitoba. Session 19I4, p. 839 . 
MORE ADMINISTRATIVE REFORMS, WITH EXTENSION

OF GOVERNMENT CONTROL; ACCOUNTS SHEW

ANOTHER DEFICIT IN I 9 I 4 AND IMPROPER

USE OF TELEPHONE FUNDS

The following year, the fiscal year ended November 30, 1914, was the seventh year of Government ownership and operation of telephones. It also marked the beginning of a period of depression. The crop of 1913 in the prairie Provinces had been unsatisfactory, immigration had fallen off and even the towns had begun to react after the decade of prosperity they had experienced. The harvest of I9 I 4 was again short, immigration practically ceased, and in August the outbreak of the war found Manitoba in a precarious financial condition. The Provincial Government had exercised their borrowing powers freely, there had been continuous speculation in both rural and urban land for several years and the anticipated expansion of production had not taken place. The new transcontinental railroad lines were approaching completion and the stimulus to trade which the construction period had involved, had passed away. There would undoubtedly have been a period of depression in the Northwest, even if the war had not taken place. ${ }^{39}$

The Annual Report of the Government Telephones for the fiscal year was not issued until August

${ }^{30}$ Cf. The Canada Year Book 19I4, Ottawa igrs.
1915. Although the Report made no mention of any proposed administrative change, the Report of the Public Utilities Commission showed that further reorganization of the system was contemplated. In the latter Report the Public Utilities Commissioner wrote: "The present telephone management having reached a stage of operation at which it seems advantageous to do so, there is being formulated a code of organization such as is in use in large telephone enterprises, but adapted to these conditions. This is for the guidance of the higher officials and to systematize the work." ${ }^{40}$ Although this statement gives no indication of the nature of the reorganization to be effected, it is clear that the administration of the system has been in a state of constant change, - a condition which in itself must have precluded efficiency.

In regard to the telephone accounts for the year, ${ }^{41}$ it is immediately noticeable that the endorsement of the chartered accountants who had audited the accounts for 1912 and 1913 is lacking. In the Annual Report of the Government Telephones no explanation is offered as to this apparent absence of audit; the reason, however, is given in the following extract from the Report of the Public Utilities Com-

40 Third Annual Report of the Manitoba Public Utilities Commission for the year ending November $30 t h, 19 \pi_{4}, \mathrm{p} .4$.

41 Seventh Annual Report of the Manitoba Government Telephones for the fiscal year ending November 3oth, 19I4, pp. 3-4, I4-19. 


\section{I38 GOVERNMENT TELEPHONES}

missioner: "The method of reporting the audit, both monthly and annually, was changed in I9I4. Until recently the auditors reported to the Commissioner of Telephones, and held their appointments from him. It was decided that that appointment should be by the Government, and the monthly and annual reports made to the Provincial Treasurer. That course is now being followed." 42 In other words, the Government had taken back much of the control over the telephone finances which it had been necessary for it to yield at the time of the "reorganization" in I9I 2 : the reports and recommendations of the auditors could easily be ignored or suppressed. Although the power which the Government had been obliged to surrender in 19 I 2 was, all things considered, not very great (for the power to exert influence for political purposes they had never given up), nevertheless no further evidence is necessary to prove that the Government had begun to manœuvre with the object of ultimately recovering every possible vestige of the power over the system which had been theirs during the first four years of Government operation.

Except for the absence of the auditors' certificate, the accounts for 1914 were similar in form to those for I9I3 - and they showed about the same result. After the deduction of interest charges and a depre-

\footnotetext{
42 Third Annual Report of the Manitoba Public Utilities Commission for the fiscal year ending November 3oth, 19I4, p. 4 .
}

\section{REORGANIZED}

ciation charge of $\$ 409,536$, there was a "surplus" of $\$ 56,067$, of which $\$ 54,824$ was set aside as an additional reserve against depreciation, leaving a credit "balance" of $\$ 1,243$. The depreciation charge, too, was based upon precisely the same erroneous and unscientific calculations as in $1913^{43}$ and, being equivalent to only $4.8 \%$ of the plant cost at the end of the preceding year, was inadequate to precisely the same degree. When the depreciation charge is increased to an amount sufficient to pro. vide an adequate contribution to the depreciation reserve, the accounts stand thus:

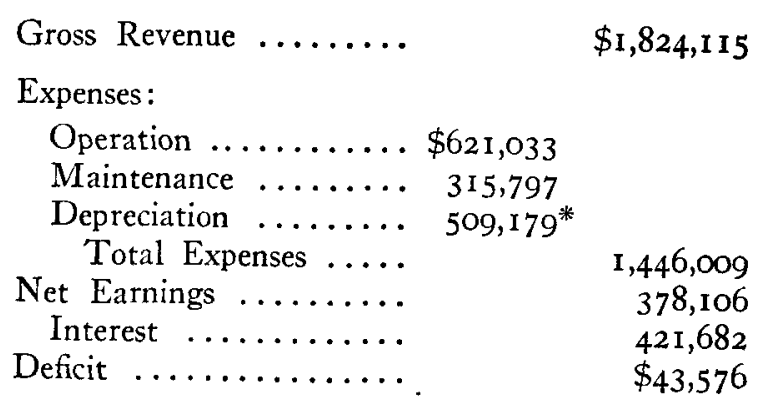

Equivalent to $6 \%$ of plant cost at the end of the preceding year.

Although this loss of at least $\$ 40$, ooo was - unfortunately for the taxpayer - highly unsatisfactory, yet it was a slight improvement over the result in I9I3. However, inasmuch as gross revenue from exchange service during the year increased to an average of $\$ 32.00$ per telephone, it is apparent that

43 Cf. pp. 127-128, supra. 
the financial improvement was again due, not to economies or efficiencies in operation, but almost solely to increased revenue secured from subscribers. Since, however, the average revenue from exchange service is already at the maximum possible under the present rates, the evidences of Governmental extravagance and inefficiency which are revealed upon a close examination of the accounts cannot much longer be concealed from the public unless there is another substantial increase in rates. In the future, analysis of the accounts may be expected to show that the system is actually losing more and more each year.

One statement in the Annual Report for I9I4 is highly significant. Referring to reconstruction expenses, the Telephone Commissioner wrote: "As the age of the telephone plant is extended it will be found that the expenditure on account of renewals and reconstruction of the plant, due to extraordinary weather conditions, obsolescence and inadequacy, will increase accordingly." 44 These words give whatever confirmation is needed of the existence of $e x$ traordinary weather conditions, that is, conditions which should properly require extraordinary depreciation reserves. The statement also implies that extraordinary depreciation should have been provided for year by year and an adequate reserve built

44 Seventh Annual Report of the Manitoba Government Telephones for the fiscal year ending November 30th, 1914, p. I4. up to meet it. This policy was of course not adopted nor is it adopted now. In view of these conditions there can be no question that an annual depreciation charge equivalent to 6 per cent. of plant cost at the end of the preceding year is certainly a distinctly moderate provision against reconstruction requirements. Indeed, a sound policy in respect to extraordinary depreciation due to the climatic conditions of Manitoba would demand an increase in the annual depreciation charge over and above 6 per cent. An annual depreciation charge of 6 per cent. has been used here in recasting the accounts merely to avoid even the appearance of an exaggeration of the real losses of the Government system. Since the plant costs upon which the depreciation charges have been based have also been understated rather than overstated, ${ }^{45}$ there can therefore be no question that the aggregate losses during the seven years of Government operation were at least $\$ 650$,ooo. These losses, too, were incurred from a system which included fewer telephones than there are in either of the single cities of Toronto, Ontario, ${ }^{46}$ or Milwaukee, Wisconsin. ${ }^{47}$

According to the Annual Report, the unexpended depreciation reserves deposited with the Provincial Treasurer at the end of I9I4 amounted to the sum

${ }^{45} \mathrm{Cf}$. pp. 1 52-1 54, infra.

${ }^{46}$ The Toronto $W$ orld, January 9, I9I6.

${ }^{47}$ The Milwaukee Sentinel, June 17, I915. 
of $\$ 731,515.4^{48} \quad$ Now, although this sum was an absurdly inadequate reserve, nevertheless it had been large enough to attract the attention of the members of the Government. It seems that the total of the trust funds (which included the unexpended depreciation reserves of the telephone system) in the hands of the Government at November 30, 1914, was \$1,5 I 4,231.77 in nominal cash, but that only $\$ 150,529$ of these funds was in actual cash. ${ }^{49}$ In order to conceal this discrepancy between nominal cash and actual cash it further appears that the Government borrowed from the bank, by means of an overdraft, the balance between these two sums, viz., \$1,363,702.$77^{50}$ This transaction was clearly a piece of "window dressing," the plain fact being that the trust funds, including the telephone reserves, had been used for the current expenses of the Province.

In any discussion of the finances of the Manitoba telephone system, considerable emphasis must be laid on the far-reaching effects, especially in a period of depression, of the existence of this burdensome Government ownership and operation instead of efficient private operation constantly contributing to the public purse in the form of taxes.

There can be no doubt that the addition to the

48 Seventh Annual Report of the Manitoba Government Telepones for the fiscal year ending November 3oth, 1914. p. I4.

49 Sessional Paper No. I. Sessional Papers. Legislative Assem. bly of Manitoba. Session 1915, pp. 8 and 17.

50 Ibid., p. 5. Cf. also the Manitoba Free Press, Winnipeg, February $25,1915$.

\section{REORGANIZED}

143

Provincial debt of the indebtedness incurred for telephone purposes and the extravagant way in which the telephone funds have been expended, have seriously compromised the credit of the Province. This result would have occurred even in normal times, traces of it were noticeable prior to I9I4. The ultimate reactions of the financial difficulties into which the Province has fallen as a result of experiments in public ownership, can only be a matter for conjecture; but in any case, it would appear that the progress of Manitoba must be seriously retarded, while during the immediate future the Province will be unable to extend its governmental activities even in advisable directions, will be forced to curtail expenditure on telephone construction still more, and may be involved in difficulty in procuring funds for other necessary and urgent purposes. ${ }^{51}$

\section{THE TELEPHONE MANAGEMENT A CAMPAIGN ISSUE; \\ EXTENSION OF TELEPHONE SERVICE LESS THAN \\ THAT IN THE UNITED STATES; THE PASSING OF THE GOVERNMENT}

The summer of I9I4 saw a closely contested general election and in the bitter campaign which preceded it, the management of the telephone system was one of the chief bones of contention, as was to be expected. The Opposition raked the entire history of the enterprise over the coals, illuminating

${ }^{51}$ Cf. p. 32, supra. 


\section{I44 GOVERNMENT TELEPHONES}

with perfervid invective the painful contrast between promise and performance. "The people of Man"itoba," cried the Opposition, "are not getting as promised a better service at half the rates charged by the Bell. The prices have been increased very considerably. The inability of the Government to keep its pledges . . . is the result chiefly of overcapitalization ... wasteful construction methods and inefficient administration, the direct consequence of persistent manipulation of the system in the interest of the Government machine." ${ }_{52}$ The Opposition press was filled with varied charges of political manipulation, favoritism, incompetence and graft in the administration of the system; particularly bitter was the charge that the Government were making use of the system in every way (for example, by having employees working at a distance transported to their respective polling places at the expense of the Province ${ }^{53}$ ) in order to "swing" the election to their own party.

In view of the fact that irrefutable proof of the accuracy of many of the charges of the Opposition was public property, the Government candidates were hard pressed for adequate rebuttal. Indeed, in a number of instances they more or less frankly admitted that the Government had made "mistakes" in their telephone policy and were unable to fulfill

52 Liberal Handbook IOI4, p. 94.

${ }^{5} 3$ Cf. the Manitoba Free Press, Winnipeg, July 2, r9i4. their promises. ${ }^{54}$ Other candidates spoke vaguely about "splendid" service and expatiated upon the theoretical advantages of public ownership as compared with alleged "extortions" of private capital. .55 Some "pointed with pride" to the extension of the service into the rural districts. Almost the only defence of the rates which they devised, however, was comprised in statements to the effect that "the 'phones of the province did not cost as much per 'phone as the 'phones in the provinces to the west" ${ }_{56}$ (where there is also public ownership) and that telephone rates in New York City were higher than those in Winnipeg ${ }^{57}$ - this latter statement being meaningless in view of the fact that the Government had learned, to their sorrow, that unit costs increase with the number of telephones in an exchange. Of course, in such a maze of charge and counter-charge, it is quite impossible to determine where the exact truth lies. It is inconceivable that the Opposition did not magnify their charges of political manipulation, of inefficiency, and of graft; but that there existed considerable foundation for such charges cannot be denied. As to rates, the Government themselves admitted their failure to redeem their promises.

There is, however, one defence of the Provincial

54 Cf. the Manitoba Free Press, Winnipeg, July 8, 19r4.

${ }^{55}$ Cf. The Evening Telegram, Winnipeg, July 8, I9r4.

${ }^{56}$ The Evening Telegram, Winnipeg, July 7, 1914.

${ }^{57}$ Cf. the Free Press News Bulletin, Winnipeg, July 8, r914. 


\section{I46 GOVERNMENT TELEPHONES}

telephone system which the then Government party always pleaded in extenuation of all their sins. This defence is the Government's record in extending the system, for whereas the system comprised only some I 4,000 telephones at the time of its acquisition from the Bell Company in January 1908 , at the end of 1914 it included some 46,000 telephones. ${ }^{58}$ During a period of seven years the Government had added 32,000 telephones and had more than tripled the size of the system. Although the fact that political rather than social motives impelled this extension detracts a certain amount of glory from the achievement, nevertheless it is quite true that the development secured by the Government is highly creditable. But the allegations and insinuations of the adherents of the Government to the effect that this extension would never have been secured under any régime of unrestricted private enterprise are utterly unjustifiable, for there is not a scrap of evidence to warrant any conclusion that private initiative would not have developed the service to a similar extent. In the first place, as has already been pointed out, it must be remembered that the Bell Company had borne all the burdens and assumed all the risks of the pioneer, that it had gone into Manitoba at a time when there were only some 60,000 people in the entire Province, when the population of Winnipeg was

58 Seventh Annual Report of the Manitoba Government Telephones for the fiscal year ending November 3oth, IgI4, p. 8. only 8,00o and when Brandon and Portage la Prairie were mere villages. ${ }^{59}$ The service which the company initiated at that time it nurtured through all the successive periods of hardship and depression until a substantial business had been developed. The Manitoba Government, therefore, merely took over an established business and took it over in a period of expansion and prosperity which the Bell Company had anticipated and prepared for. ${ }^{60}$ Consequently, it is apparent that as regards physical extension, no proper comparison can be made between the record of the Bell Company and the record of the Government. The only possible comparison which can be made is between the record of the Government in Manitoba and the record of private enterprise in similar communities in the United States, that is, in communities with large farming populations. ${ }^{61}$ A glance at the telephone history of the United States, as shown by the statistics published by the Bureau of the Census at Washington, suffices to show that the progress made by the Manitoba Government is by no means unusual under private management, while as regards the present development of the service, the development in Manitoba is considerably exceeded by that in the States of the Union which are most

59 Cf. p. 13, supra.

Bo Cf. pp. 26-28, supra.

61 Comparisons with the Provinces of Alberta and Saskatchewan, the only similar Canadian communities, are unfortunately impossible, as public ownership of telephones obtains in both of these Provinces as well as in Manitoba. 
analogous to the Canadian Northwest. According to statistics prepared by the Government, at the end of I9I4 the total number of telephones in the Province of Manitoba was equivalent to an average of 95 telephones per I, OOO population; ${ }^{62}$ according to the statistics of the United States Bureau of the Census the number of telephones in Illinois and in Iowa, the greatest farming States of the Union, were respectively equivalent to $\mathrm{I} 39$ and to $\mathrm{I} 7 \mathrm{I}$ telephones per I, Ooo population, while in Kansas, the great wheat State, and in Minnesota, the great barley State, the corresponding averages were I4I and I 27 telephones per 1,000 population. ${ }^{63}$ In other words, in communities which are very similar in their economic and social aspects, the development of the telephone service is from 34 per cent. to 80 per cent. greater under private ownership than under public ownership. ${ }^{64}$ Such official statistics effectually dispose of any contention that unrestricted private enterprise could not, and would not, have secured in Manitoba as great a degree of telephone development as has been secured under Government control.

The general election of 1914 again returned the

62 The Manitoba Free Press, Winnipeg, February 20, 1915.

63 Telephones and Telegraphs and Municipal Electric Fire-Alarm and Police-Patrol Signaling Systems. Department of Commerce. Bureau of the Census. Washington 1915. Pages $15-16$.

${ }_{64}$ Incidentally, the U. S. Census telephone statistics, which are the latest available figures, are for the year 1912 , whereas the telephone development throughout the United States considerably increased during 1913 and I914. The above percentages, therefore, are really too favorable to the Manitoba system.
Government to office. But only a narrow margin separated the victors from the vanquished and it was abundantly clear that the Government were rapidly losing prestige even in the rural districts. The misdeeds of the Government and the failure of their ventures in public ownership had been proved costly and were destined to prove fatal, for so strong grew the Opposition that in the spring of the year I9I5 the Government was forced to appoint a Royal Commission to investigate the charges against the administration. The Oppositon had prepared their case well and the evidence before the Commission soon revealed not only incompetence and inefficiency, but led to the prosecution of the Cabinet Ministers in the criminal courts for fraud. Before long the accumulation of testimony and proof was such as to shake the nerve of even the most hardened politician. The Premier and his colleagues decided to resign and, in May I9I 5 , they surrendered the Government to their political opponents without an election. ${ }^{65}$

This change of political masters marks the end of what may be termed the second phase of the history of the Manitoba Government telephone system. During the three years comprised in the period, there is less spectacular evidence of the political influence with which the system was inevitably surrounded. The Government realized that the whitewash ap-

65 In order to assure themselves of popular support, the new Government subsequently (in August) held a special general election, at which they were continued in office. 
plied by the Royal Commission would serve to deceive only the more credulous among the voters. For publicity purposes, therefore, the Government went through the motions of a "reform." As a reluctant but necessary concession to public opinion, they relegated a certain amount of regulatory power, largely innocuous, to the Public Utilities Commissioner. The chief feature of the period, however, was that the Government, having interpreted the political handwriting on the wall, became even more elaborate in their pretenses and even more subtle in their manipulations, though they openly maintained their arbitrary attitude toward the consumer. The violation of their pledges continued. The promises as to rates were repudiated and the "exorbitant" rates of the former Bell Company were exceeded; political control continued to preclude the possibility of commercial management; and the ownership and operation of the system continued to be a burden on the finances and credit of the Province.

SYSTEM USED FOR POLITICAL PURPOSES BY THE NEW GOVERNMENT; AN AGGREGATE LOSS

$$
\text { OF } \$ \mathrm{I}, 000,000
$$

At the time of writing the new Government have not been in power long enough to permit a critical review of their policies and performances to be undertaken; and the public mind has been so intent upon the world conflict that printed information as to the telephone system is relatively meagre. Short as has been the tenure of office of the present Government, however, certain of their acts and certain of the immediate results of their administration are nevertheless significant as unmistakable auguries of their future relations with the telephone system.

In the first place it will be recalled that the political partisans of the new Government had always contended that the price paid for the Bell plant had been excessive. ${ }^{66}$ Immediately upon assuming the reins of power in May, 1915, the Government sought to substantiate this claim; and for this purpose the Attorney-General in the Provincial Cabinet "requested a statement showing the plant valuation of the Manitoba Government Telephones." 07 In pursuance of this "request," officials of the telephone system made a valuation of the plant and submitted a report of their findings under date of June $23 \mathrm{rd}$. "Complying with instructions," says this report, "we have compiled unit costs of all plant additions made during the period from January rst, I908, to November 3 oth, I9I4, and, by applying these unit costs to the plant as purchased, ${ }^{68}$ find the construction costs of total plant to be $\$ \mathrm{I}, \mathrm{I} 38,568$ less than stated in the last annual report. ${ }^{69}$ Of this amount $\$ 802,336$ per-

${ }^{60}$ Cf. pp. 29 and 94-95, supra.

${ }^{67}$ The Tribune, Winnipeg, July 5, 1915

68 "The plant as purchased" evidently means the total plant at November 30 , I9r4.

69 Viz., Seventh Annual Report of the Manitoba Government Telephones for the fiscal year ending November 3oth, Igr4. 


\section{I5 GOVERNMENT TELEPHONES}

tains to the original purchase, ${ }^{70}$ and the remainder consists of amounts charged to construction, but properly chargeable to maintenance, during the three years following the purchase." $i 1$

That this hasty and unscientific valuation - a valuation on the basis neither of original cost nor of cost of reproduction new - was undertaken largely for political purposes, is clear; for if the object of the valuation had been merely to measure the excess of the book value of the plant over its original cost (or over its cost of reproduction new) at the time when the present Government had assumed control of the system, it would have been unnecessary to devote either the time or the money to estimating the construction cost of the portion of the plan acquired from the Bell Company seven years before. ${ }^{72}$ The portent of this appraisal is ominous: efficiency and economy will apparently always be subordinated to political advantage.

As the valuation was unscientifically based upon the "unit costs of all plant additions made during the period from January Ist, I908, to November 3oth, I9 I4," it is clear that the figure of $\$ 1,138,568$ in the appraisal report cannot be an accurate measure-

$70 \mathrm{I}$. e. the purchase of the Bell plant.

71 This appraisal report was subsequently printed in Eighth $\mathrm{An}$ nual Report of the Manitoba Government Telephones for the fiscal year ended November 3oth, 1015, pp. 4-5.

72 An estimate of the construction cost of the Bell plant was of course necessary to determine the portion of the excess of book value pertaining to the purchase of the Bell plant. ment of the excess of the book value of the plant over its actual cost of construction; but in view of the partisan spirit in which the unit costs were without doubt - though possibly unconsciously - compiled and applied, it seems certain that the effect of errors operating to increase the excess of book value must have been greater than the effect of errors operating to reduce this excess. The result, then, is that the figure of $\$ I, I 38,568$ in the appraisal report is probably somewhat too large. Nevertheless, for the purpose of the revisions of the accounts of the system in these pages the appraisal figure has been accepted at its face value, and in recasting the accounts the amount of the excess of book value pertaining to the purchase of the Bell plant, - an amount which represents the price paid for the intangible items involved in the purchase, ${ }^{73}$ — has been excluded in toto from the cost of the plant as shown by the annual accounts; and the total amounts $(\$ 336,232)$ representing the maintenance expenses improperly charged to construction (or capital) during the first three years of Government operation has also been excluded from the cost of the plant as shown by the annual accounts, the amount so charged to capital in each of the years having been carefully estimated. ${ }^{74}$ The result is that the moderation and the conservatism of the results of the recast accounts have been enhanced: the plant cost (after the deduction of the

${ }^{73}$ Cf. pp. 29-31, supra. $\quad{ }^{74}$ Cf. pp. 54-55, supra. 


\section{54}

excess of the book value over the cost of construction) being too small, consequently the annual depreciation charges based upon the plant cost are too small, the total current expenses are too small, and the annual deficits are too small.

Now, in recasting the accounts, the maintenance expenses improperly charged to capital in the first three years, after being deducted from the book cost of the plant, have been properly added to the current expenses for "Maintenance" in those years; but no charge has been included in the current expenses of any year to provide for the gradual extinction of the amount of $\$ 802,336$ paid for intangible assets. There can be no question, however, that this intangible capital should eventually be written off and that, for this purpose, a charge should properly have been included each year in current expenses; indeed, the necessity for making such annual provisions for extinguishing intangible capital is recognized in the appraisal report, which states: "I would recommend that the excess in plant values be carried as intangible capital, and charged off in annual installments." 75 If, upon the acquisition of the Bell Company's plant, the Government had decided to write off this intangible capital in equal annual installments during a period of as long as fifteen years, the amount properly chargeable to each year would

${ }^{75}$ Eighth Annual Report of the Manitoba Government Telephones for the fiscal year ended November 30th, 1915, p. 5 . have been about $\$ 50,000$, or an aggregate sum of $\$ 350,000$ for the seven years of Government operation ending November 30, I9I4. Since the aggregate losses of the system during the seven years, exclusive of these charges for amortization of intangible capital, reached the sum of $\$ 650,000$, the total losses from Government operation up to the end of 1914 aggregated at least a million dollars!

INCREASING DEFICITS DESPITE REPORTS OF PROFITS; NO PROSPECT OF RELIEF FROM POLITICAL ABUSES

The telephone accounts for the fiscal year ended November 30 , $1915,{ }^{76}$ published in June, 1916, show a "surplus" of $\$ 22,54 \mathrm{I}$, of which $\$ 19,646$ was set aside as an additional reserve against depreciation, leaving a credit "balance" for the year of only $\$ 2,895$. Although the balance sheet shows that the Plant Account had been reduced during the year so as to represent the actual cost of construction of the plant as determined by the appraisal - the excess of the former book value of the plant over its cost of construction $(\$ \mathrm{I}, \mathrm{I} 38,568)$ being carried as intangible capital, as recommended by the appraisal report - yet in determining the amount of the depreciation charge included in the current expenses of the year no change was made in the calculation of the

${ }^{76}$ Eighth Annual Report of the Manitoba Government Telephones for the fiscal year ended November 3oth, 19I5, pp. 3-4, 12-18. 


\section{I56 GOVERNMENT TELEPHONES}

average life of the plant. Therefore, since the same rates of depreciation were applied to reduced plant values, the result was that through a mere change in the form of the accounts, the depreciation charge became smaller instead of greater as it should have been. When an adequate depreciation charge is included in the current expenses, the result is as follows :

$$
\text { Gross Revenue ......... }
$$$$
\$ 1,769,589
$$

\section{Expenses:}

Operation $\ldots \ldots \ldots \ldots \$ 602,366$

Maintenance ....... 320,839

Depreciation ....... 525,510* Total Expenses .....

Net Earnings ...........

Interest $\ldots \ldots \ldots \ldots \ldots$

Deficit...$\ldots \ldots \ldots \ldots$.

$$
\begin{array}{r}
1,448,715 \\
320,874 \\
418,503
\end{array}
$$$$
\$ 97,629
$$

* Equivalent to $6 \%$ of plant cost at the end of the preceding year.

Therefore, the real result of the year's operations was a loss of about $\$ 100,000$, exclusive of any charge for writing off intangible capital, - the largest annual loss since I9I2. Even allowing for the decrease in business during the year, in view of the fact that the Telephone Commissioner said that " the policy of economy, as adopted for the year, was judiciously applied wherever possible" and spoke of the year's results as "gratifying," 77 the future of

77 Eighth Annual Report of the Manitoba Government Telephones for the fiscal year ended November 3oth, 1915, p. 3. the telephone finances is indeed a matter of grave concern.

When the system was placed under the supervision of the Public Utilities Commissioner in $1912,{ }^{78}$ the Commissioner decided that a condensed statement of the earnings of the system should be issued each month. This practice, which has since been continued, was beneficial in so far as the Public Utilities Commissioner could govern it; ${ }^{79}$ but the accounts relating to interest upon the telephone capital did not fall within the Commissioner's jurisdiction. Consequently, these monthly statements of earnings have not shown, and do not show, interest charges; they show merely the excess of revenue over operating expenses, exclusive of interest charges - in other words, they show net earnings and not net profits. Now, these monthly statements have been widely circulated by the press; but in the press reports the net earnings in the statements have frequently been mistaken for net profits. For example, the report of the statement for September I9 5 in The Tribune of Winnipeg is headed " Month's Telephone Profits $\$ 42,441.23$ " and begins: "Manitoba government telephones brought in a net profit of $\$ 42,411.23$ in

${ }^{78}$ Cf. p. II8, supra.

79 Subsequent to the change of Government in 1915 , the Public Utilities Commissioner, whose influence upon the system was salutary in so far as he had authority, resigned. In any consideration of the probable future relations of the Government with the telephone system, the apparent significance of his resignation should not be overlooked. 


\section{I58 GOVERNMENT TELEPHONES}

the month of September, according to a return issued to-day. The net profit for that month and the preceding nine months was $\$ 330,330.46$." 80 Such reports naturally induce utterly false conclusions.

In the campaign preceding the bye-elections held in mid-summer, $1915,^{81}$ the Government were naturally able to make effective use of their predecessors' record of continuous mismanagement. The appraisal report had also been completed in time to make an excellent basis for campaign arguments. But the Government and their political partisans went even further in their efforts to secure campaign material: the Government press called the appraisal " a preliminary investigation" and promised a "far more searching inquiry into the telephone enterprise "if the Government were continued in office. ${ }^{82}$ In other words, promises in regard to the telephone system were once again used to attract votes; and the Government made no effort to conceal the fact that they were ready to use the system for political advantage by instituting an expensive "searching inquiry" which could serve no useful purpose. This attitude on the part of the present Government clearly indicates that a change of political masters has not meant a change of political methods.

The utter futility of the Manitoba Government's invasion of the domain of commercial business is

so The Tribune, Winnipeg, October 30, 1915.

81 Cf. p. 149, note 65 , supra.

82 The Manitoba Free Press, Winnipeg, July 26, I9r 5. shown by the unconcealed dissatisfaction which is rife at the present moment - dissatisfaction which, in spite of publicity work on the part of the Government, shows no evidence of subsiding. For example, the Manitoba Government Telephones is now denounced as " one of the most iron-clad monopolies imposed on any people "; ${ }^{83}$ and complaint is made that the rates should be "cut in two" 84 - the identical language employed eight and nine years ago during the political agitation against the Bell rates!

The people of the Province still have no prospect of ultimate relief from the abuses accompanying political control.

${ }^{83}$ The Winnipeg Telegram, December 6, 1915.

84 Ibid. 
IV

\section{CONCLUSIONS}

The net results of the foregoing narrative of the course of events and the critical examination of the accounts may be summarized as follows:

$I^{\circ}$ The telephone system was taken over by the Government not in obedience to widespread public demand, nor on any administrative ground properly so called, nor because the existing service was inadequate in scope or exorbitant in price, nor because sufficient capital was not forthcoming for extensions; but solely because the Provincial Government thought they saw in its acquisition a party political advantage. In other words, the Government acquired the system not to promote the public interest in any real sense, but to promote the political interest of the Government party in such a way as to contribute to keep the Government in power.

$2^{\circ}$ The promises made by the Government in order to stimulate a public interest which did not previously exist were made in some cases certainly without knowledge of the subject, in other cases probably without intention of fulfilment, in all cases without justification. $3^{\circ}$ From the beginning of public ownership, the telephone system was used for political purposes, sometimes overtly, at other times furtively, but always with a cynical disregard for the interests of the public.

$4^{\circ}$ The technical management of the system was always subordinated to the political management. Even rates were determined not by the Commission appointed by the Government, but by the Government itself; and in fixing these rates the Government discriminated sharply against the urban areas. This discriminatory policy was not unskilfully conceived. It was a policy of dividing to conquer; for by setting the interests of the classes who are in the majority against the interests of the citizens who are in the minority, the Government secured a political advantage.

$5^{\circ}$ From the beginning the Government employed the balances of money in the hands of the Telephone Commission for its own general purposes. It also absorbed the funds which should have been held in trust for the replacement of worn-out plant. It neglected to provide an independent continuous audit and when, forced by local public opinion, it did call for an audit, it failed to adopt the important suggestions of its own auditor.

$6^{\circ}$ The unsound financial policy and the mismanagement of the Government brought the telephone system to the pass that either the revenue had to be 
increased or the system had to be permitted to gravitate rapidly into hopeless insolvency. In either case the disclosure had to be made that the acquisition of the telephone system had not really been attended by the success that the Government had been constantly announcing. The straightforward thing for the Government to have done would have been to admit the faults of their administration, to vindicate the Commission, to provide out of the general revenues of the Province the whole amount of the estimated loss at that period, and at the same time to ask the Commissioners at what rates they were prepared to conduct the business. None of these things was done; instead, the Government proceeded to make the Commission a scape-goat, appointed a Royal Commission to inquire into the conduct of the Commissioners - that not being at all in question and avoided scrupulously all reference to the Governmental blunders and misdeeds that had brought the telephone system into discredit.

$7^{\circ}$ The Government secured the resignations of the Commissioners and proceeded to make hurried "reforms." These reforms were expensive; but as they were all made in a month it may be inferred that they were not very thorough. The new era of the telephone system was, however, ushered in by the appointment of an overseer in the person of the Commissioner of Public Utilities. But even with these changes, there is no evidence of any change of prac- tice on the part of the Government. The fact is that the Government was not inclined to abandon the political leverage given it by an industrial enterprise whose operations were so widely extended throughout the Province.

$8^{\circ}$ Then came the evacuation by the Government of a position which had been rapidly becoming insecure. The members of the Government resigned and their places were taken (without an immediate election) by their opponents.

$9^{\circ}$ A spectacular incident in Provincial politics occurred when the members of the Government which had just resigned, were prosecuted for conspiracy, fraud, etc.

IO ${ }^{\circ}$ Then came the resignation of the Public Utilities Commissioner; and owing partly to the conditions induced by the war, but more largely to conditions in the previous history of the telephones, development of the system was arrested.

I I $^{\circ}$ The entire history of the Government telephone enterprise in Manitoba affords evidence of the most positive character against Government ownership. Practically all of the defects which have emerged elsewhere in the management of industries by State officials have made their appearance in the case of the Manitoba Telephones. The management has been ineconomical, the enterprise has been handicapped by political intrigue, the finances mingled as they have been with the general finances of 


\section{I64 GOVERNMENT TELEPHONES}

the Province have been unsoundly administered from the beginning, and the obligations of the public have been enormously increased without adequate compensatory advantages.

It is possible that only by repeated and costly failures such as the Manitoba Government Telephones, will the public realize that the proper function of Government is not the conduct of industries but the impartial inspection of them under intelligent laws adapted to the character and conditions of the community and the country.

THE END

\section{INDEX}

Accountancy practice of Government Telephones condemned by Chartered Accountants, in8

unsound from beginning, $4 \mathrm{x}$, $53,58,68$

See also Accounts

Accounts of Government Telephones, as published, (1908) 51; (1909) 69; (rgro) 78; (I911) 82; (1912) 124-125; (1913) 127; (1914) I39; (1915) 155

as recast according to sound methods, (1908) 58; (I909) 69; (I910) 79; (r911) 83 ; (1912) 126; (1913) 129; (1914) 139; (1915) 156

condemned by Chartered Accountants, ro8

criticized by Opposition, $52-$

fail ${ }^{53,60}$ to include interest charges, $69,72,78,82$, 125

fail to include provision against depreciation, $4 \mathbf{I}$, $60,69,71-72,78,8 x, 82$, $86,93-94$, I07

fail to provide any Sinking Fund, $7 x$

improperly include Maintenance expenses in capital, $54,55,60,68,78, \times 52$

include inadequate depreciation charge, 125, 127-128, I39, I55-156
Accounts-continued

include interest charges, 127, 138

include unearned revenue, 53 , 60

Method of recasting, 54-57, 153-154

not properly audited, 74

show Maintenance expenses as separate item, 125

Administration of Government Telephones, Organization of, $3^{6-38}$

Reorganization of, $67, \quad 116$, I37

Admissions by Government of failure to fulfill promises, 145

Advisory Telephone Board appointed, II8

Alberta, Telephone system in, viii, $65,147 \mathrm{n}$.

Appraisal of Government telephone plant (1915), I5I

basis for campaign arguments, $x 58$

Arbitrary telephone rates, 121

Armstrong, Dr., M. P. P., 73

Attorney-General of Manitoba, I9, 21,73

Audit, Absence of, 74

Change of system of, $x 37,138$ ineffectual, $16 \mathrm{I}$

Auditor, Telephone accounts not audited by Provincial, 74

Australia, Telephones in, 9I

Barry, Mr. R. L., of Minneapo- lis, appointed Royal Com- 
Barry, Mr. R. L.-continued missioner (1912), 97

Interrogations of, ror

appointed sole Telephone Commissioner, 115

assumes duties, II 6

resigns, I16

Bell Telephone Company, 13 $14,15,16,18,19,21,22$ 23, 25n, 26, 27, 28, 29, 35 $36,42,45,45 \mathrm{n}, 48,52,59$, $59 \mathrm{n}, 76,87,93,95,113$, 129, 146, 147

Birtle, Manitoba, 23

Brandon, Manitoba, I3, 14, 22, 106, 147

Bulletin, The (Winnipeg), 68n.

\section{Canada Year Book 1914, 136}

Canadian Finance, ro7

Canadian Independent Telephone Association, 2 In.

Capital account of Government Telephones, inflated by improper addition of Maintenance expenses, 55 , $60,68,78$

expenditure of Bell Telephone Company, 26-27

Census of Canada, IgII, 13

Chicago (Ill.), Telephones in, 97

Christie, Mr., Member of Committee on Telephones, Industrial Bureau of Winnipeg, 94

Citizen, The (Ottawa), $17 \mathrm{n}$.

Climate. See Depreciation

Coldwell, Mr., Member of Manitoba Government, II3

Commercial management of telephones promised by the Government, 33-35

Commission, Royal. See Royal Commission
Commission, Telephone, appointed, 36

Membership of, $36-37$

Original functions of, 36,37

lacks full power, $37,38,4 \mathrm{r}$, $66,69,70-7 x, 72,78,104$, 107, 138

subjected to political pressure, $38-42,43,44,46,64,74$, $84-86,106,107$

additional functions of, 46

introduces functional organization, 67

forces Government to meet deficit or increase rates, $8 \mathrm{I}-82$

puts into effect reduced local rates (1909), 62-64

increases long distance rates, 88

proposes to increase local rates (I9II), 88-90

Government expresses confidence in, 96

investigated by Royal Commission of Inquiry, 96III

made scapegoat for Government, 99

loyal to Government during inquiry of Royal Commission, 102

made to appear responsible for practices over which it has no control, 103-109

resigns, 112

Mr. R. L. Barry appointed sole Commissioner, I 5

resigns, 116

Mr. G. A. Watson appointed sole Commissioner, 117

placed under supervision of Advisory

Board, 118

given more independent power, II 8 increases rates (I912), I2I

Committee on Private Bills (Manitoba Legislature), 16

Competition in telephone service prevented by Manitoba Government, I22123

Construction of telephones, Control over, by Government, $37,38,39,109$

Feverish energy in, 43

ineconomical and marked by political abuses, 38, 43, $76-78,81,83-86$, 105

Not all, justifiable, $38,75,84$ retarded, II8, I43, 163

to be let on contract under reorganized system, 123

Cost, Promises by the Government to provide telephones at, 18, 50, 52

per unit, Decrease of, under reorganized system (1912), I17

Increase of, with increased number of telephones in use denounced by the Government as a "fallacious theory,"' I9

proved to increase with increased number of telephones in use, 145

Credit of Province damaged by Government ownership of telephones, 32, 47, 70, 143,150

Criticism of Government undertakings by public not usually instructed or effective, 4

Crowe, Mr. G. R., Royal Commissioner (x912), 96

Debt, Effects of increase in public, $6,1 \mathrm{I}$
Debt-continued

of Manitoba doubled by the acquisition of Bell telephone system, 3I

See also Credit

Defence by the Government of its telephone policy, 146

Deficit of Government Telephones after accounts are recast on a sound basis, (1908) 58; (1909) 69; (1910) 79; (I9II) 83; (1912) 126; (1913) 129; (I9I4) 139; (1915) 156

as published (I9II), 82

concealed by unsound accounting practice of the Government, 58 et passim pointed out by Opposition press, 52-53

exceeds $\$ 300,000,8_{3}$

at least $\$ 650,000$,

aggregates at least $\$ I, 000,000$ I 55

may be expected to continue, I 40 , I 56-I 57

Depreciation not provided for $54,7 \mathrm{I}-72,78,8 \mathrm{I}, 82,86$, $93-94$, I07

rapid on account of climate of Manitoba, 55, 55n, 128 , 140

charge, Absence of, criticized by the Industrial Bureau and the Board of Trade of Winnipeg, 94

Absence of, noticed by $\mathrm{Op}_{\mathrm{p}}$ position, 60

inadequate, 125, 127-128, 139, I 55-1 56

included in current expenses for the first time, 12

Method of calculation of, unscientific, 128

ought in the case of Manitoba to be at least 6 per 
Depreciation-continued cent. annually, 55, I4I

placed under supervision of Public Utilities Commission, 118

recommended by Telephone Commission and refused by Government, 41, 56, 86

reserve improperly applied, 142

Depression of trade in Manitoba (1914), 136

Deterioration of service, Alleged, 93, 106, $13 \mathbf{x}$

Detroit News Tribune, $48 \mathrm{n}$.

Development of telephone system retarded from various causes, 118, 143, 163

Disadvantages of public ownership. See Public ownership

Discrimination in service, 39 , $43-44,84$

Dominion Government refuses to amend charter of Bell Telephone Company, I6I7

Parliament and the telephone question, 65

Eastern Canada, I5n.

Election, General (1907), 25; (1914) $143,148, \quad 149$; (I915) $149 \mathrm{n}, 15^{8}$

Employees appointed for political reasons, 40, 44, 6667, IO4

incompetent, 104-ro5

used for political purposes, 144

See also Labor, Patronage, Wages

Europe, Telephones in, 15

Evening Telegram, The (Winnipeg), $145 \mathrm{n}$.
Farmers' telephones. See Rural telephones

Finance. See Accounts, Deficit, Depreciation, Overdrafts, Profits

Finances of Manitoba, 25, 47, $136,143,150$

Financial methods of the Government in relation to the telephone system, 4I, 70$72,80,86,104,142$

results of Government operation of telephones. See Accounts

Free Press News Bulletin (Winnipeg), 145n.

Friction between Telephone Commission and employees, 67, Ir7. See also Employees, Labor

Gazette, The (Montreal), 36

Germany, Telephones in, 9I

Government ownership. See Public ownership

Government of Manitoba confesses ignorance of the telephone business, 96

Increase of control by, in 1914 , 138

Relations of, to Telephone Commission, 39, 97, 99, II 8

See also Political pressure Governmental management of industrial enterprises ineconomical, 6-7

Grain elevators, Public, xrgn.

Great Britain, Telephones in, 9I, I3I-I 32

Hayes, Mr. W. H., Commissioner Engineer (First Telephone Commission), 37,68

Resignation of, II3
Head office expenses proposed to be saved under Governmental management of telephones, 33

functions, rog neglected by Manitoba Government, 38

Herald, The (Montreal), $17 n$.

Horan, Mr. H. J., Commissioner Auditor (First Telephone Commission), appointed 37

Memorandum by, $44,85,86$

Resignation of, 112

House of Commons (Canadian) Misleading statements as to the financial resulis of the Manitoba Government Telephones made in (I909), 65

Hydro-electric system for Manitoba proposed and re jected, 32

Illinois, Telephones in, 148

Independent Telephone Company of Canada, $16 \mathrm{n}$.

Inspection rather than operation the proper function of Government, 164

Intangible capital, 29-31, 59, 95 I 53,154

ought to be written off by annual instalments, 59, 154

Interest. See Account

Iowa, Telephones in, 148

Journals of the Legislative Assembly of Manitoba, $16 \mathrm{n}$, $17 \mathrm{n}, 19 \mathrm{n}, 50 \mathrm{n}, 6 \mathrm{n}, 74 \mathrm{n}$ $75 \mathrm{n}$, IOIn, $118 \mathrm{n}$.

Kansas, Telephones in, 148

Labor difficulties in Manitoba Government telephone system, 66-67, 83-84, ro4, 130

Scarcity of, 44, 77, 104

La Crosse (Wis.), Telephones in, 97

Legislation permitting munici pal ownership and operation of local telephone exchanges ( I 899), I 5

Legislature of Manitoba, I6, I9, $27,29,34$

Liberal Handbook (1914), $\mathrm{I}_{44}$

Locke, Mr. Justice, Royal Commissioner (1912), 96

Long Distance service, 18,20 , $25,43,87$

Loss in operation of Manitoba Government Telephones. See Deficit

Maintenance expenses improperly charged to capital, $54,55,60,68,78,152$

shown as a separate item 125

Manitoba Free Press (Winnipeg), I6n, 18n, 20n, $21 \mathrm{n}$ 23n, 24n, 25n, 26n, 27n, $3 \mathrm{In}, 32 \mathrm{n}, 33 \mathrm{n}, 34 \mathrm{n}, 43 \mathrm{n}$, $45 \mathrm{n}, 46 \mathrm{n}, 47 \mathrm{n}, 48 \mathrm{n}, 49 \mathrm{n}$ $5 \mathrm{on}, 52 \mathrm{n}, 53,53 \mathrm{n}, 60 \mathrm{n}$ $67 \mathrm{n}, 76,77 \mathrm{n}, 85 \mathrm{n}, 88,88 \mathrm{n}$, $97 \mathrm{n}, \quad 105,106 \mathrm{n}, \quad 107 \mathrm{n}$ I12n, I16n, 122n, $123 \mathrm{n}$ $\mathrm{I} 42 \mathrm{n}, 144 \mathrm{n}, 145 \mathrm{n}, 148 \mathrm{n}$, $158 \mathrm{n}$

Manitoba Government and Public Ownership of Telephones, The, 23

Measured service rates introduced (r909), 63

proposed to be made compulsory for business lines in Winnipeg, 90

plan dropped, roo Milwaukee Sentinel, The, rurn 
Milwaukee (Wis.), Telephones in, 141

Minister of Public Works, 16 , I7, 50, 55n, 6r

Telephones and Telegraphs, 32, 37, 45-46, II 8 . See also Telephones and Telegraphs, Department of Railways

Minneapolis Journal, $48 \mathrm{n}$.

Minneapolis (Minn.), Telephones in, 97

Minnesota, Telephones in, $\mathrm{I}_{48}$

Morning Fost, The (London), I32n.

Municipal Act (Manitoba), I5

agitation for public ownership of telephones in Manitoba, 15

exchanges, Isolation of, $\mathrm{I} 6$ ownership of telephones in Manitoba, 15, 19, 24, 25, $45 \mathrm{n}$.

Neepawa, Manitoba, 15, 21 New York Tribune, $48 \mathrm{n}$.

Ninga, Manitoba, Dismissal of telephone agent at, on political grounds, $67 \mathrm{n}$.

North West Telephone Company, 16

Official Report of the Debates of the House of Commons (Canada), 65n, 66n.

Opposition party in Manitoba Legislature, $20,29,50,60$, Ior, x43, 144, 449

attacks the terms of telephone purchase, 29, 3I criticizes telephone accounts, 60,74

criticizes telephone administration, 144
Opposition party-continued moves for Committee on telephone system, ror

press and Government telephones, 26, 3I, 43, 47, 50, $52,53,92, x 44$

criticizes telephone accounts, 52-53

criticizes increase of rates, 92

Orders-in-Council (Manitoba), $37,41,46,96$

Ottawa Free Press, The, $\mathrm{r} 7 \mathrm{n}$.

Overdrafts from Bank by Telephone Commission, 6o, 86, 142

Paris, Telephones in, 15

Paterson, Mr. F. C., first Chairman of Telephone Commission, $36,55 \mathrm{n}, 70,72$, $85,9 \mathrm{I}, 107, \mathrm{IIO}, \mathrm{II} 3$

Patronage in telephone administration, Political, 44, 46, $84-85$, ro4

Piper, Mr., member of Committee of Industrial $\mathrm{Bu}-$ reau of Winnipeg, 94

Poles for telephones, Excessive numbers of, purchased by the Government, $39-40$, ro3

Political origin of agitation for Government ownership of telephones, 16, 18, 22, $25,34,35,160$

pressure exercised on telephone management, 38$42,43,44,46,50,64,66$, $67,74,76,84-86,103,106$, 107, I1 8, I38, 444

Apparent decline of, 149

Apparent revival of, under new Government, 152,158

promised to be avoided, 34
Political origin-continued

upon Telephone Commission other than Governmental, 85

situation in Manitoba in 1906,

Portage la Prairie, Manitoba, I3, 14, 147

Postmaster General of United States on cost of rural mail delivery, r23n.

Private enterprise and the telephone, Manitoba, 13-29, 122-123

United States, 148

Profits, Fictitious, Io, 4x, 48, 49 , $5 \mathrm{I}, 6 \mathrm{I}, 65,69,7 \mathrm{O}, 78,8 \mathrm{O}$, $125,127, \times 39$

under new Government, $\mathrm{I} 55, \mathrm{I}_{57-1} 8$

promised under Government ownership, 19-20, 32-33, 35

See also Deficit

Promises. See Commercial management, Profits, Rates

Public Accounts of Manitoba, 25n, 50, 69n.

Committee (Manitoba Legislature), $60,64,70,72 \mathrm{n}$, $73 n, 74,86 n$.

Exploitation of the Government telephone system by the, 45

interests wholly overlooked in Government administration of telephones, $16 \mathrm{I}$

ownership, Future of, as affected by the war, $\mathbf{x}$

not suitable or necessary for telephone business, 24

Origin of, in Manitoba, summarized, 34-35

Pecuniary disadvantages of 5-6
Public Accounts-continued

Results of, in foreign countries, $x-9$

Social disadvantages of, 2 $5,8-9$

Utilities Commission, 118 $124,128 \mathrm{n}, 130,157,157 \mathrm{n}$. approves rate increase (1912), 121

Beneficial influence of, II9, 127

Purchase of the Bell telephone system by the Government, 26, 28, 29, 95, I5 154

price of Bell telephone system, 28

criticized by Opposition and defended by Government, 29-3 I, 94-95

not unreasonable, $3 \mathbf{r}$

of telephone supplies controlled by the Government, 37,40

Rates promised to be "cut in two," 19, 21, 22, 35

reduced considerably, 17,19 , 23,32

reduced to "cost," 18,20 , 50,52

Retention of Bell Telephone Company's, 47

Sectional increase of (x908), 42,47

Reduction of, by Government for political purposes (1909), 62-64, 73

Unjustifiability of, $66,81,86$ Increase of long distance, 88 Proposed increase of ( $\mathrm{I}$ II ), 88-90

technically justifiable, $9 \mathrm{I}$

Violent opposition to, 92-93 abandoned (I9I2), 100

Reports upon, by Winnipes 
Rates promised-continued Board of Trade and Industrial Bureau, 93-94

placed under supervision of Public Utilities Commission, I 18

General increase of (1912), $I 2 x, 144,145, I 5^{\circ}$ increases revenue by $\$ 200$,ooo per year, 129

produces insufficient revenue, $x 40$

complained of by public, I 59

of Bell Telephone System in the United States, r29

Private company offers to reduce, 122

General schedules of, $62-63$, $89, x 21$

Rebates demanded on the ground of announcement of fictitious profits, 50

Reconstruction costs improperly charged against current revenue, 56, ro4

properly charged against $\mathrm{De}$ preciation Reserve, 25

Telephone Commissioner anticipates great increase of, 1 to

Reorganization of Government Telephones, (r909) 67; (1912) $x 16$

Plan for (1915), 137

Report by independent accountants on Government bookkeeping system, 108

of American Telephone and Telegraph Company (1913), r29n.

of Citizens' Committee of Inquiry as to Local Telephone Rates (Winnipeg Industrial Bureau), 94

of Manitoba Government
Report-continued

Telephones, 53, 55n, 68, $75 \mathrm{n}, \quad 78 \mathrm{n}, \quad \operatorname{ros} \mathrm{n}, \quad$ II $5 \mathrm{n}$

II $6 \mathrm{n}, \quad$ I $7 \mathrm{n}, 124 \mathrm{n}, \quad 125^{\mathrm{n}}$

$127 \mathrm{n}, 128 \mathrm{n}, 130 \mathrm{n}, 137 \mathrm{n}$

$r_{4} \mathrm{n}, \mathrm{I}_{42 \mathrm{n}}, \mathrm{r} 46 \mathrm{n}, 15 \mathrm{rn}$

I $52 \mathrm{n}, \mathrm{x} 54 \mathrm{n}, \mathrm{x} 5 \mathrm{n}, 156 \mathrm{n}$.

of Public Utilities Commissioner of Manitoba, r2mn, I3on, r35n, 137, r $38 \mathrm{n}$.

of Royal Commission of Inquiry into Telephone Commission (1912), 97 , roo, 112

of Telephone Committee (Winnipeg Board of Trade), 94

Resignation of Manitoba Government (1915), I49

of Public Utilities Commissioner (Mr. Robson), I $57^{\mathrm{n}}$.

of Telephone Commission, 112

Resolutions and Memorials of the Legislative Assembly of Manitoba respecting Public Telephones (1906), 20 .

Roblin, Sir Rodmond (Premier of Manitoba), 16, 17, 21, $27,29 \mathrm{n}, 33,96 \mathrm{n}$.

Resignation of, 149

Robson, Mr. H. A., K. C. (Public Utilities Comissioner), I 8,157

Beneficial influence of, 119 , $\mathbf{1 2 7}$

Resignation of, $157 \mathrm{n}$.

Rome, Telephones in, 15

Royal Commission of Inquiry into Telephone Affairs appointed, 96

Scope of inquiry of, 99

Stenographic report of, 39 , 97
Royal Commission-continued

Public indifference to, 98

Interim report of, 100

Evidence before, ror

Influence of Government upon, 101, 102

makes no reference to $\mathrm{De}$ preciation Reserve or Sinking Fund, I07

Final report of, 97-98

Unsatisfactory character of final report of, III

attempts to vindicate the Government at the expense of the Telephone Commission, II

to investigate charges against the Manitoba Government (I915), 149

Rural municipalities, I5

rates, Reduction of, by Government for political purposes, 62-64, 73

Proposed increase of (I9I I) , 88-90

Increase of (1912), 12

telephones, Cost of installation of, 85

Extension of, 38, 43, 8I, 84, 106, 147

promised on behalf of the Government at \$r per month, 23

Salaries. See Wages

Saskatchewan, Telephones in viii, $65, \mathrm{r}_{47} \mathrm{n}$.

Schedule of rates, (1909) 62$63 ;$ (1911) $89 ;$ (1912)

Service, Quality of, Alleged deterioration of, 93, 106, rerion

under Bell Telephone Company, I 8

under Government admin-
Service-continued

istration, 47-48, 93, 106, 131, I33-I 35, I 44

Sessional Papers of Manitoba Legislature, $25 \mathrm{n}, 29 \mathrm{n}, 37^{\mathrm{n}}$, $5 \mathrm{In}, 56 \mathrm{n}, 64 \mathrm{n}, 68 \mathrm{n}, 69 \mathrm{n}$ $72 \mathrm{n}, 73 \mathrm{n}, 75^{\mathrm{n}}, 79 \mathrm{n}, 83 \mathrm{n}$, $86 \mathrm{n}, 97 \mathrm{n}, \quad x 00 \mathrm{n}, \quad 105 \mathrm{n}$ I $6 \mathrm{n}, 126 \mathrm{n}, 142 \mathrm{n}$.

Sinking Fund, No provision for 7r, 107

Sise, Mr. C. F. (President of the Bell Telephone Company of Canada), invited to discuss terms of purchase, 28

State action, Habit of leaning upon, 98

collectivism, Oscillations in attitude of public towards, 2

usually adverse to technical progress, 2

monopoly, Effects of, 2 Statutes of Manitoba, I5n, 20n, 24n, 25n, I18n.

St. Paul (Minn), Telephones in, 97

Strike threatened by Winnipeg telephone employees, 67 Subscribers, Number of. See Telephones, Number of

Surplus. See Profits

Taxation, Government Telephones free from, 59n, I42

involves reduced yield from, 142

of Bell Telephone Company, $59 n$.

Telephone Commission. See Commission, Telephone

Commissioners. See Commission, Telephone

Telephones and Telegraphs, 
Telephones-continued

Department of Railways, $29,30,32,36,45-46$

See also Minister of Telephones and Telegraph

Number of, $1_{3}, x_{4}, 27,28,75$, I4I, I46

Growth in, not due to Government control, 76, $146-$ 148

Telephone system in Manitoba, Beginning of $(x 880), x_{3}$

Purchase of, by Bell Telephone Company of Canada ( I 88r), I3

Extension of $(1882-84), 13$

Economic depression causes slow development of (1888-1905), 14

Character of immigration retards development of, r4

Rapid expansion of (rgoo1908), 15

Inquiry by Government into, x 6

Application of Manitoba to Dominion Government to amend charter of Bell Company rejected, 16-17

Project of joint Governmental and Municipal ownership, $x 7$

Policy of Government regarding, 18,20

Committee of Legislature on (1906), 19

Alleged exorbitant rates of, x 9

Rates to be "cut in two" by Government, I9, 2I, 22

Construction of competitive Government system in Winnipeg ( 1907$), 23$

Municipalities reject Government policy in respect to 24
Telephone system-continued

Purchase by the Government of the Bell, 26

Position at the time of purchase of the, 27

Terms of purchase of, 29-3I Promises of Government regarding, 32, 33, 35

First Commission appointed to manage, $3^{6}$

Commission for management lacks full power, 37

Political pressure upon, $3^{8}$ et seq.

Abolition of technical staff in Telephone Department, 46

Opposition criticism of, 47

Alleged surplus from, 48

Political importance of, 49

Accounts of (1908), 5 I

Real deficit in, 53

Current expenses of, improperly charged to capital, 54

Necessity of recasting accounts of, 54

Absence of Depreciation $\mathbf{R e}$ serve in, 55

Deficit (1908), $5^{8}$

Opposition criticism of accounts of, 60

Reduction of rates in, 62

Unremunerative farmers' rate in, 64

Influence of misstatement of financial results in, 65

Labor difficulties of, 66

Reorganization of, 67

Deficit in (1909), 69

Public Accounts Committee, criticism of, 70

Political abuses in, 76

Deficit in (r9ro), 79

Crisis of (rgrr) $8 \mathrm{I}$

Disappearance of fictitious "surpluses," and admis-
Telephone system-continued sion of heavy loss upon, $8 \mathrm{I}$

Deficit in (rgrr), 83

Specific causes of financial failure of the, $83 \mathrm{et}$ seq.

Political influence in, 85

Long distance rates increased in, 88

New local rate schedule proposed for, 89,90

Measured service proposed for, 90, 9r

Hostility to rates proposed for, 92

Royal Commission of Inquiry upon, 96

Public indifference towards Commission upon, 99

Employees of, incompetent and appointed for political purposes, I04, 105

Alleged deterioration of service in, 106

Resignation of Commission for management of, II2

Appointment of sole Commissioner for, II 5

Resignation of Commissioner for, 116

Appointment of new Commissioner for, $\mathbf{I I} 7$

Public Utilities Commissioner to supervise, $\mathrm{II} 8$

Rates increased in, 12

Deficit in (1912), 126

Deficit in (1913), 129

Unsatisfactory service, I3 I et seq.

Auditor's certificate absent from accounts of (r914), 138

Deficit in (19r4), 139

Anticipated increase of reconstruction charges in, I 40
Telephone system-continued

Misuse of trust funds of, $\mathbf{r}^{2}$

Credit of Province damaged by, 143

Influence of change of Government upon (I9I5), 149

Appraisal of plant of, $15 x$

Political influence still exercised upon, I 52

Aggregate loss upon, $x_{55}$

Deficit in (1915), 156

Misleading statement of financial results of, $\mathbf{I} 57$

Conclusions regarding, 160 et seq.

Telephony, 49n.

Toronto, Ontario, Telephones in, 141

Toronto World, The, I4In.

Trades and Labor Council of Winnipeg, 67

Treasurer of Manitoba, $5 \mathbf{I}$

Tribune, The (Winnipeg), 49n, $96 \mathrm{n}, 15 \mathrm{In}, 157 \mathrm{n}, 158 \mathrm{n}$.

Trust funds improperly applied, 142

United States, Telephones in, 19, $9 \mathrm{I}, 129,147,148$

Valuation of Bell system in Manitoba by Government engineer, 29, 30

Government plant (I9I5), $15 \mathrm{I}$

basis for campaign arguments, 158

Vienna, Telephones in, 15

Wages, Decrease of, 117,130

Increase of, 130

Dissatisfaction of employees with, $13 x$ 
War, Advantage of private ownership of telephones as preparation for, 3-4

Watson, Mr. G. A., Commissioner of Telephones, II 7

Webb, Read, Hegan, Callaghan and Company, Chartered Accountants, Report of, 108

Winnipeg, 13, 14, 22, 25, 26, 42, $89,90,91,92,93,97,98$, I00, III, I2I, I3I, I46
Winnipeg-continued

Board of Trade of, Report on rates, 93, 94, 122

Industrial Bureau of, Report on rates, 93, 94, 122

Winnipeg Telegram, The, 13n, r4n, I5n, 16n, 2in, 27n, 3on, 34n, 45n, 5on, 52n, $53 n, 62 n, 89 n, 121 n, 123 n$, $159 \mathrm{n}$

Woodbridge, Manitoba, 77 